Florida International University FIU Digital Commons

FIU Electronic Theses and Dissertations

University Graduate School

3-24-2009

\title{
Risk Based Post Closure Care Analysis for Florida Landfills
}

Banu Sizirici Yildiz

Florida International University, bsizi001@fiu.edu

DOI: $10.25148 /$ etd.FI09120823

Follow this and additional works at: https://digitalcommons.fiu.edu/etd

\section{Recommended Citation}

Sizirici Yildiz, Banu, "Risk Based Post Closure Care Analysis for Florida Landfills" (2009). FIU Electronic Theses and Dissertations. 112. https://digitalcommons.fiu.edu/etd/112

This work is brought to you for free and open access by the University Graduate School at FIU Digital Commons. It has been accepted for inclusion in FIU Electronic Theses and Dissertations by an authorized administrator of FIU Digital Commons. For more information, please contact dcc@fiu.edu. 


\section{FLORIDA INTERNATIONAL UNIVERSITY}

Miami, Florida

\section{RISK BASED POST CLOSURE CARE ANALYSIS FOR FLORIDA LANDFILLS}

A dissertation submitted in partial fulfillment of the

requirements for the degree of

DOCTOR OF PHILOSOPHY

in

CIVIL ENGINEERING

by

Banu Sizirici Yildiz 
To: Dean Amir Mirmiran

College of Engineering and Computing

This dissertation, written by Banu Sizirici Yildiz, and entitled Risk Based Post Closure Care Analysis for Florida Landfills, having been approved in respect to style and intellectual content, is referred to you for judgment.

We have read this dissertation and recommend that it be approved.

$\begin{array}{r}\hline \text { Shonali Laha } \\ \hline \text { Luis Prieto-Portar } \\ \hline \text { Mahadev Bhat } \\ \hline \text { Berrin Tansel, Major Professor }\end{array}$

Date of Defense: March 24, 2009

The dissertation of Banu Sizirici Yildiz is approved.

Dean Amir Mirmiran
College of Engineering and Computing

Florida International University, 2009 
C Copyright 2009 by Banu Sizirici Yildiz

All rights reserved. 


\section{DEDICATION}

I dedicate this dissertation to my husband Ibrahim Yildiz and to my parents Sevgi and Yilmaz Sizirici. Without their patience, understanding, support, and most of all love, the completion of this work would not have been possible. 


\section{ACKNOWLEDGMENTS}

First of all, I would like to express my earnest gratitude to my advisor, Dr. Berrin Tansel. This work would not be possible if not for her support and guidance throughout my studies. I am also thankful for her guidance, mentorship and pleasant approach since my first day at FIU and her contributions to my intellectual development.

I would like to recognize and thank to Dr. Shonali Laha, Dr. Luis Prieto-Portar and Dr. Mahadev Bhat for serving on my advisory committee.

I would like to thank to my husband Ibrahim and my parents, for their endless support and encouragement.

I would like to thank the Hinkley Center for Solid and Hazardous Waste Management for providing financial support of this research project.

I would like to thankfully acknowledge the financial support of Florida International University, Dissertation Year Fellowship. 


\title{
ABSTRACT OF THE DISSERTATION
}

\section{RISK BASED POST CLOSURE CARE ANALYSIS FOR FLORIDA LANDFILLS \\ by}

\author{
Banu Sizirici Yildiz \\ Florida International University, 2009 \\ Miami, Florida \\ Professor Berrin Tansel, Major Professor
}

Subtitle D of the Resource Conservation and Recovery Act (RCRA) requires a post closure period of 30 years for non hazardous wastes in landfills. Post closure care (PCC) activities under Subtitle D include leachate collection and treatment, groundwater monitoring, inspection and maintenance of the final cover, and monitoring to ensure that landfill gas does not migrate off site or into on site buildings. The decision to reduce PCC duration requires exploration of a performance based methodology to Florida landfills. PCC should be based on whether the landfill is a threat to human health or the environment. Historically no risk based procedure has been available to establish an early end to PCC.

Landfill stability depends on a number of factors that include variables that relate to operations both before and after the closure of a landfill cell. Therefore, PCC decisions should be based on location specific factors, operational factors, design factors, post closure performance, end use, and risk analysis. The question of appropriate PCC period for Florida's landfills requires in depth case studies focusing on the analysis of the performance data from closed landfills in Florida. Based on data availability, Davie Landfill was identified as case study site for a case by case analysis of landfill stability. The performance based PCC decision system developed by Geosyntec Consultants was used for 
the assessment of site conditions to project PCC needs. The available data for leachate and gas quantity and quality, ground water quality, and cap conditions were evaluated. The quality and quantity data for leachate and gas were analyzed to project the levels of pollutants in leachate and groundwater in reference to maximum contaminant level (MCL). In addition, the projected amount of gas quantity was estimated. A set of contaminants (including metals and organics) were identified as contaminants detected in groundwater for health risk assessment. These contaminants were selected based on their detection frequency and levels in leachate and ground water; and their historical and projected trends. During the evaluations a range of discrepancies and problems that related to the collection and documentation were encountered and possible solutions made.

Based on the results of PCC performance integrated with risk assessment, projection of future PCC monitoring needs and sustainable waste management options were identified. According to these results, landfill gas monitoring can be terminated, leachate and groundwater monitoring for parameters above MCL and surveying of the cap integrity should be continued. The parameters which cause longer monitoring periods can be eliminated for the future sustainable landfills. As a conclusion, 30 year PCC period can be reduced for some of the landfill components based on their potential impacts to human health and environment (HH\&E). 


\section{TABLE OF CONTENTS}

CHAPTER

PAGE

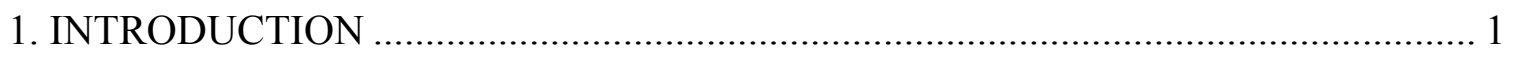

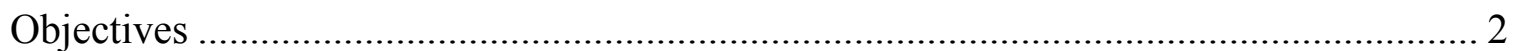

The Scope of The Dissertation..................................................................................... 3

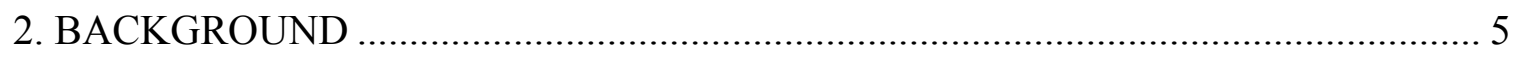

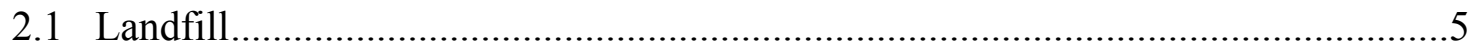

2.2 Landfill Components .....................................................................................6

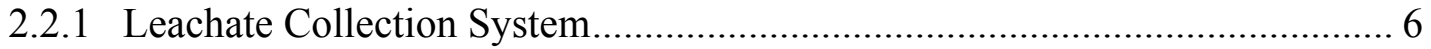

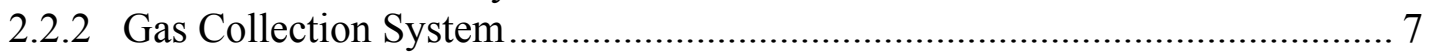

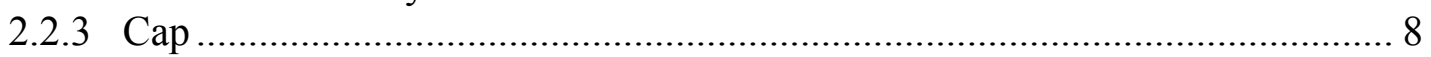

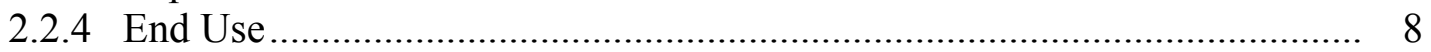

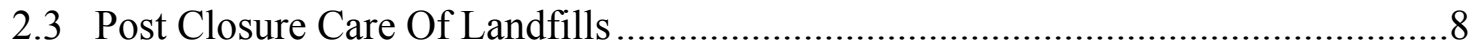

2.4 Requirements for Post Closure Care (PCC) ....................................................... 10

2.4.1 Leachate Collection and Removal System (LCRS) ....................................... 12

2.4.2 Groundwater Monitoring Systems ………………..................................... 12

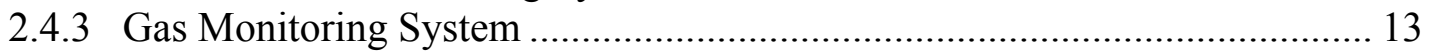

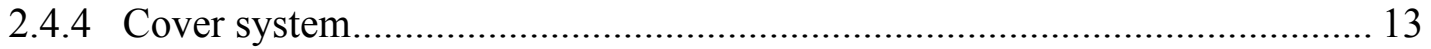

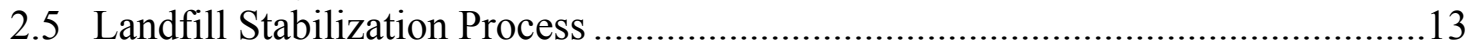

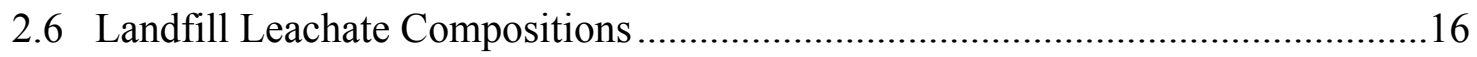

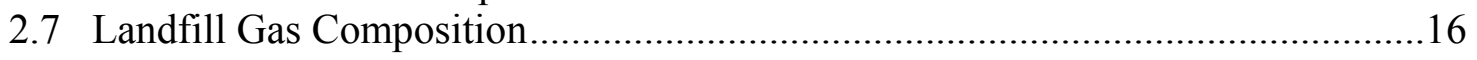

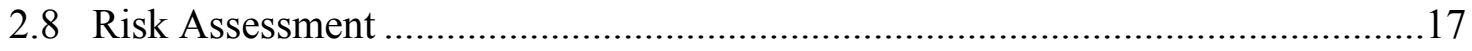

2.8.1 Landfill Risk Assessment ...................................................................... 18

2.8.2 Computer Aided Landfill Risk Assessment Approaches................................ 18

2.8.3 Selection of Best Approach For Landfill Risk Assessment............................ 21

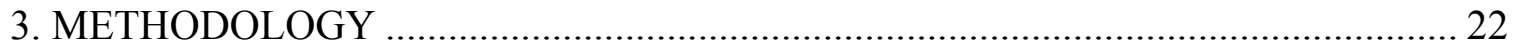

3.1 Performance Based Methodology ………………….....................................24

3.1.1 Trend Analysis Time Series Decomposition Method..................................... 26

3.1.2 Landfill Gas Emission Model (LandGEM) …………............................... 28

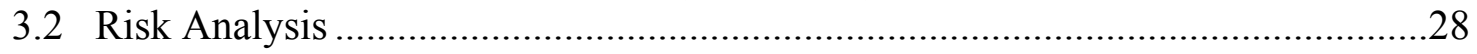

3.2.1 Sensitivity Analysis/ Factorial Design........................................................... 29

4. DAVIE LANDFILL FACILITY DESCRIPTION ………......................................... 31

4.1 Site Location and History ………..................................................................

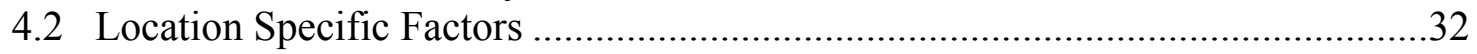

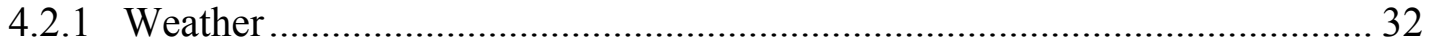

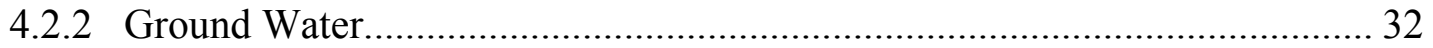

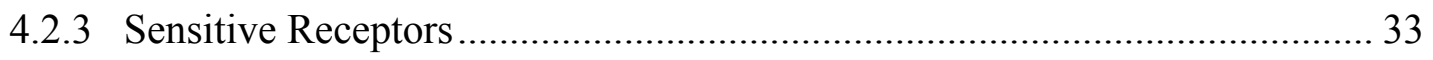

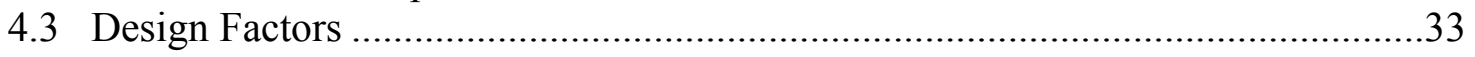

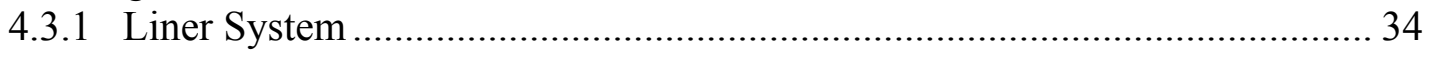

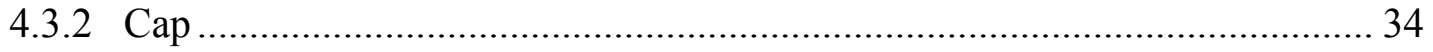




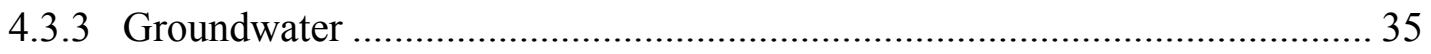

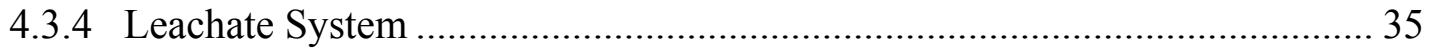

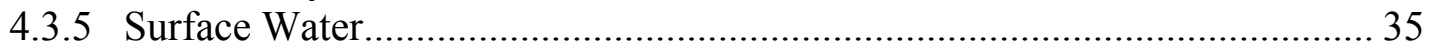

4.3.6 Landfill Gas Management System.............................................................. 36

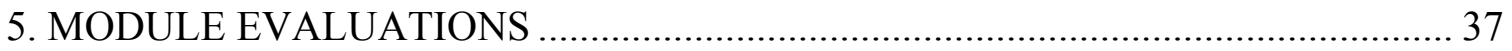

5.1. Leachate Module .........................................................................................

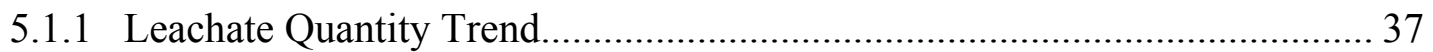

5.1.2 The Fate and Transport of Leachate ............................................................. 40

5.1.3 Leachate Quality ........................................................................................ 41

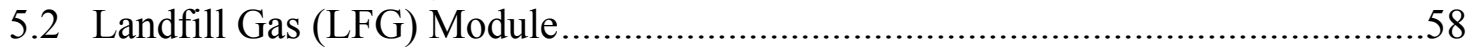

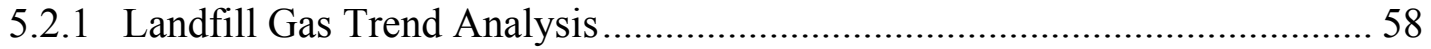

5.2.2 Remaining Gas Generation Potential Analysis............................................... 60

5.2.3 Methane Generation Rate (k) Calculations.................................................. 61

5.2.4 Potential Methane Generation Capacity (Lo) ............................................... 62

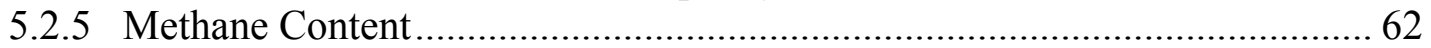

5.2.6 Comparison of LandGEM with real data....................................................... 63

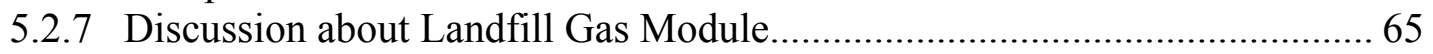

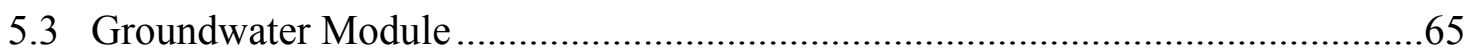

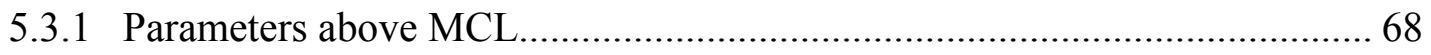

5.3.2 Parameters below MCL - Organics....................................................... 72

5.3.3 Parameters below MCL - Metals ………………..................................... 74

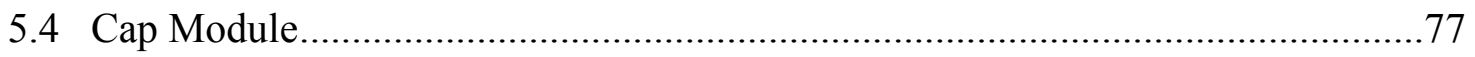

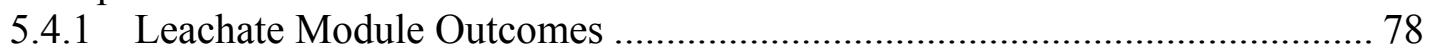

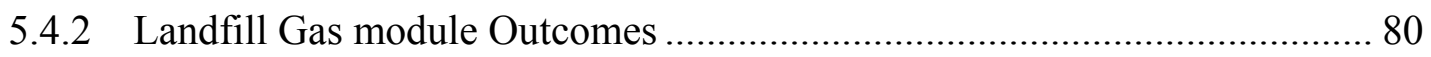

5.4.3 Cover Material Efficiency and Settlement................................................... 80

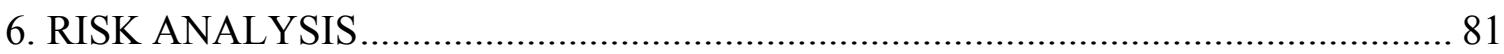

6.1 Health Effects of Contaminants of Concern Detected in Groundwater.................82

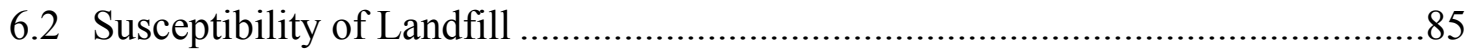

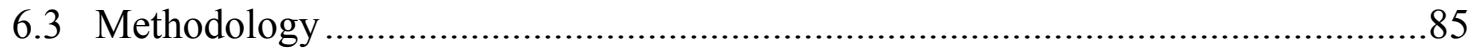

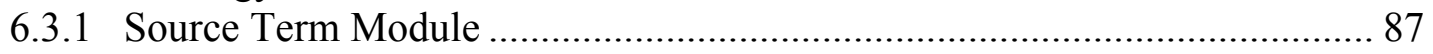

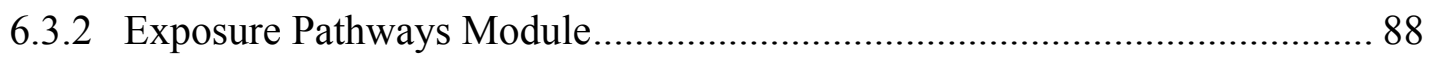

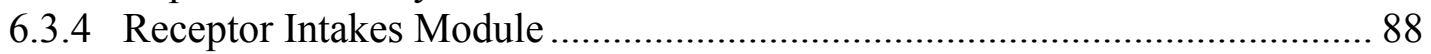

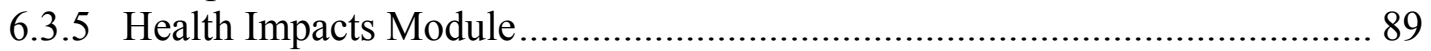

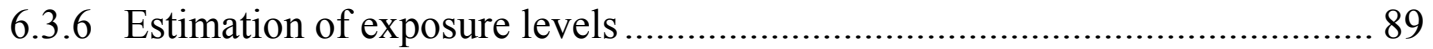

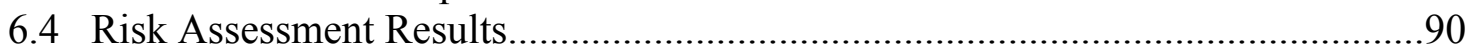

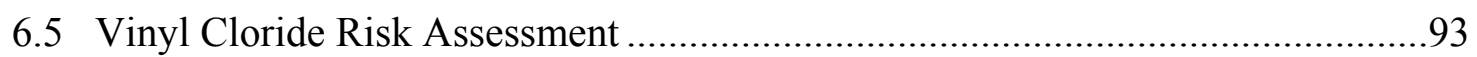

6.6 Sensitivity Analysis- Factorial Design...............................................................96

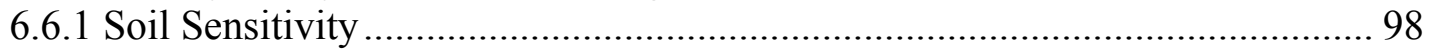

7. SEQUANTIAL DATA IMPROVEMENT FOR DAVIE LANDFILL ........................ 101

7.1 Data Quality Assessment and Improvement ......................................................102

7.2 Challenges during Compilation and Analysis of Documented Data ...................105 
8. ENVIRONMENTALLY CONSCIOUS MANAGEMENT OF WASTES DEPOSITED IN MUNICIPAL SOLID WASTE LANDFILLS........................................................... 115

9. RESULTS AND CONCLUSIONS..................................................................... 119

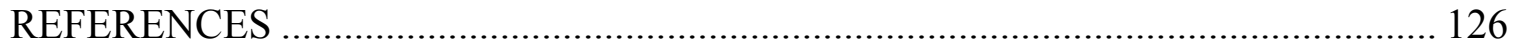

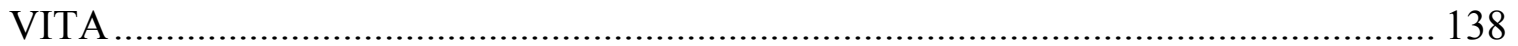




\section{LIST OF TABLES}

TABLE

PAGE

Table 1. Land use examples of closed landfills ..................................................... 8

Table 2. Leachate and gas composition at different phases....................................... 15

Table 3. Decision tree for best approach of landfill risk assessment......................... 21

Table 4. The features of Additive and Multiplicative models. ................................... 26

Table 5. Methods for determining the accuracy of the time series analysis .................. 27

Table 6. Chronicle history of Davie Landfill......................................................... 31

Table 7. Parameters of interest in leachate at Davie Landfill.................................... 42

Table 8. Leachate quantity and quality trends and general comments. ........................ 55

Table 9. Potential sources of contaminants detected in leachate................................... 56

Table 10. The accuracy of time series projections for selected leachate quality

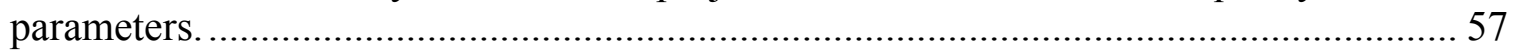

Table 11. The accuracy of time series projections of selected VOCs in leachate. .........57

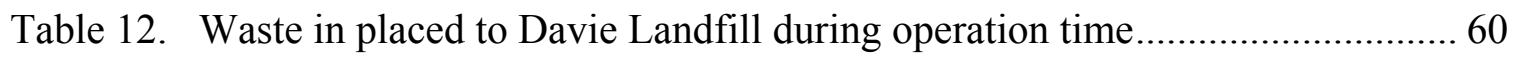

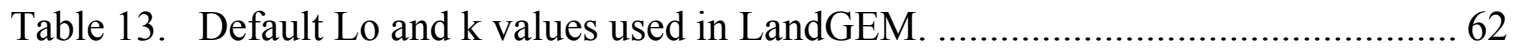

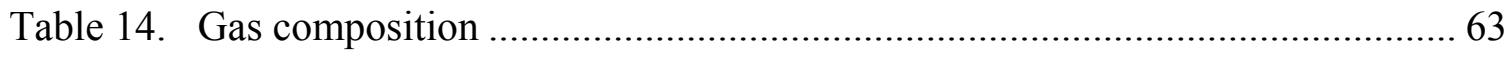

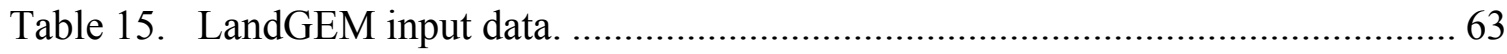

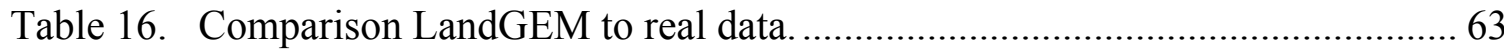

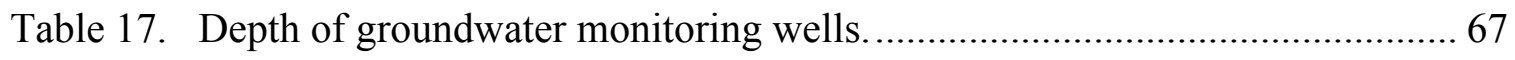

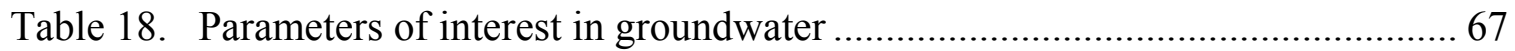

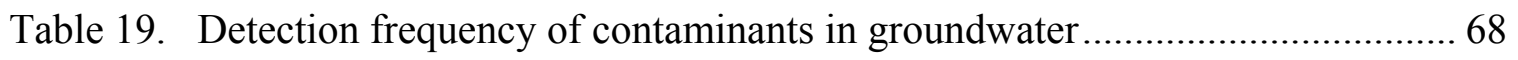

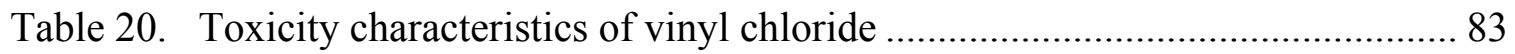


Table 21. Selected parameters for Source in Aquifer Models .................................... 87

Table 22. Selected GW parameters...................................................................... 90

Table 23. Risk calculation for vinyl chloride, chlorobenzene, 1,4 dichlorobenzene,

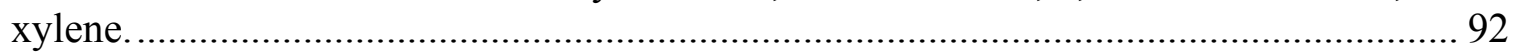

Table 24. Risk calculation for, arsenic, ammonia as Nitrogen, cadmium, chromium,

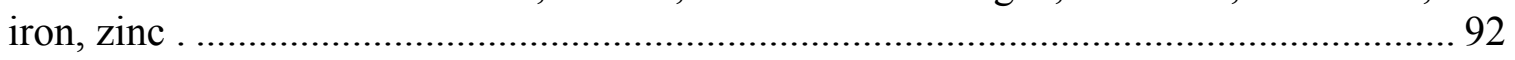

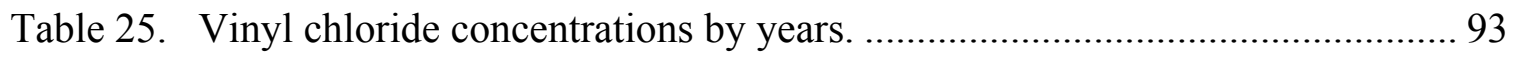

Table 26. Risk assessment summaries for vinyl chloride...................................... 95

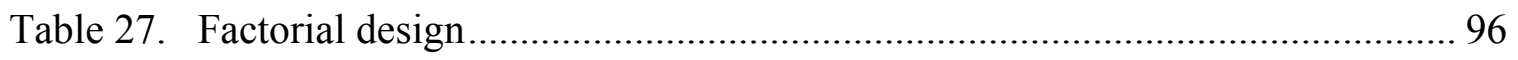

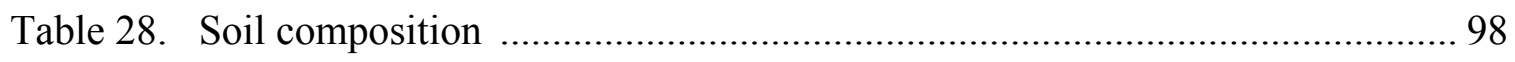

Table 29. Risk results for different soil types................................................. 100

Table 30. Roles and responsibilities of different entities...................................... 102

Table 31. Data compilation and quality improvements stages. ............................... 102

Table 32. Data quality assessment check list........................................................ 104

Table 33. Timetable of degradation of compounds in landfill based on experimental

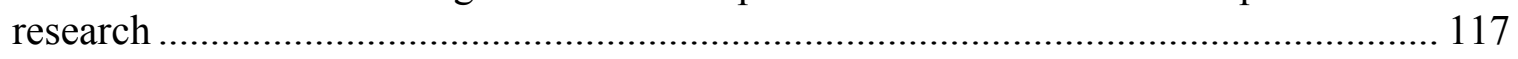

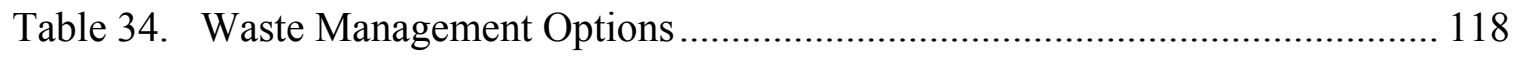




\section{LIST OF FIGURES}

FIGURE

PAGE

Figure 1. Components of leachate collection systems. ........................................... 6

Figure 2. General approach and methodology for PCC period decision.......................... 22

Figure 3. Examples of potential decision factors for PCC period. ............................... 23

Figure 4. PCC Period assessment task sequence. ................................................... 24

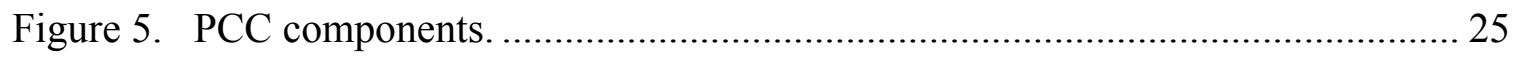

Figure 6. General location and characteristics of Davie Landfill.............................. 31

Figure 7. Sensitive receptors around the landfill area............................................ 33

Figure 8. Cross section of north mound at Davie Landfill. ....................................... 34

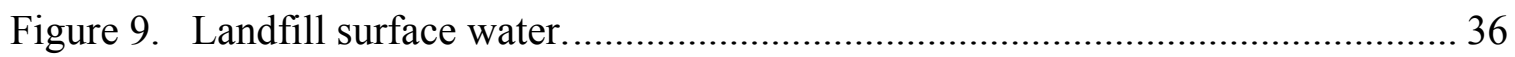

Figure 10. Annual leachate generation by years................................................... 38

Figure 11. Time series projections of monthly leachate generation ........................... 38

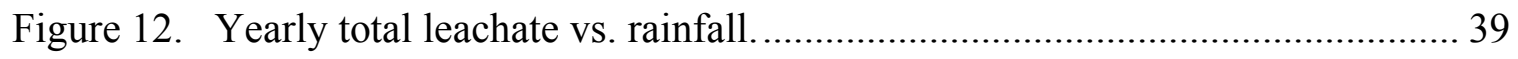

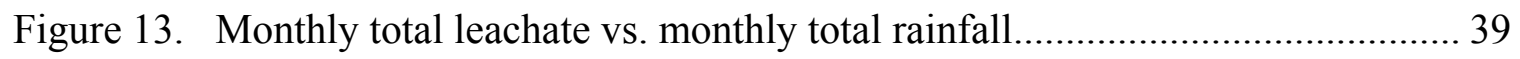

Figure 14. Average rainfall vs. average leachate at Davie Landfill............................ 40

Figure 15. Time series projection for sodium generation. ..................................... 44

Figure 16. Time series projection for chloride generation....................................... 45

Figure 17. Time series projection for Total Dissolved Solids generation. ................... 45

Figure 18. Time series projection for iron generation. ........................................ 47

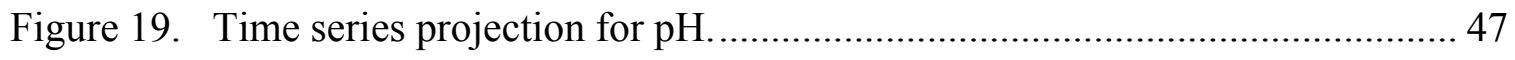

Figure 20. Time series projection for bicarbonate generation. ................................ 48

Figure 21. Time series projection for Ammonia as $\mathrm{N}$ generation.............................. 49 
Figure 22. Time series projection for vinyl chloride generation.

Figure 23. Time series projection for a) 1,4 dichlorobenzene generation b) chlorobenzene generation.............................................................. 51

Figure 24. Anaerobic formation and biodegradation of chlorinated VOCs in MSW

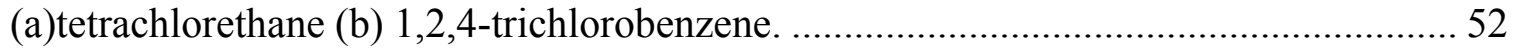

Figure 25. Time series projection for benzene generation......................................... 53

Figure 26. Time series projection for a) toluene b)ethylbenzene c)xylene d)Total BTEX

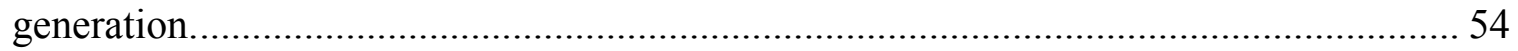

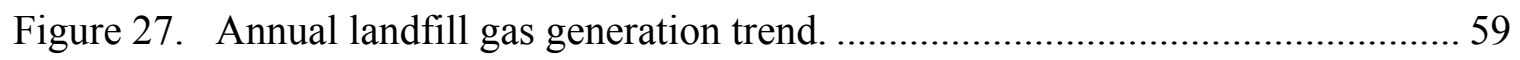

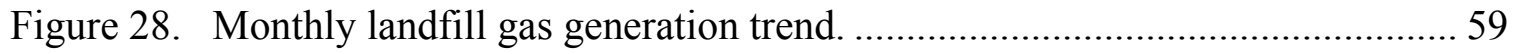

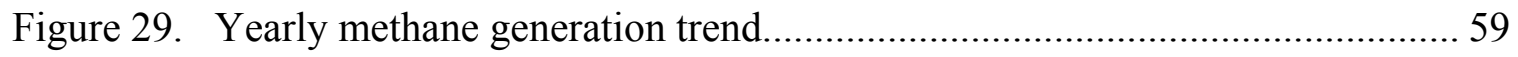

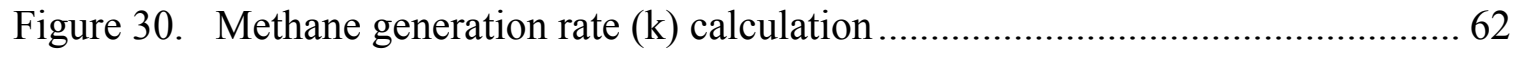

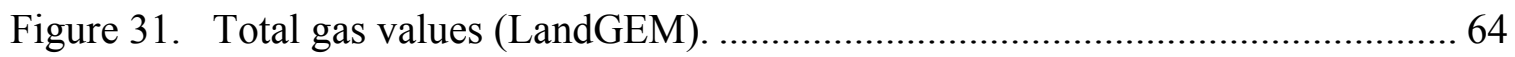

Figure 32. Davie Landfill groundwater well locations and landfill boundaries............ 67

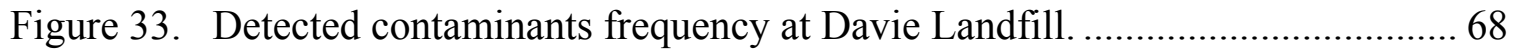

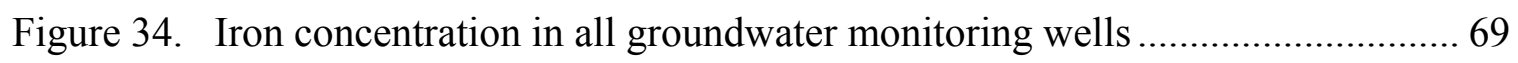

Figure 35. Ammonia as N concentration in MW11-100 ........................................ 71

Figure 36. Vinyl Chloride concentration in MW11-100 ...................................... 70

Figure 37. Organic parameters below MCL in GW monitoring wells ......................... 73

Figure 38. Chlorobenzene concentrations at Davie Landfill. .................................... 72

Figure 39. Metallic parameters below MCL in GW monitoring wells ............... 75

Figure 40. Zinc concentration in all GW monitoring wells................................... 76

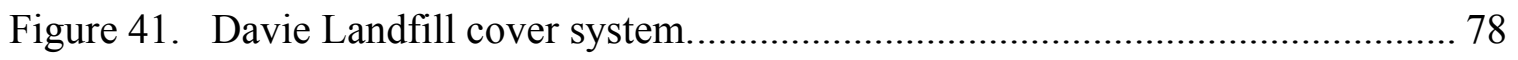

Figure $42 . \quad$ Leachate quantity changes after capping ............................................. 79 
Figure 43. Monthly total leachate vs. total rainfall correlation for assessing cap.

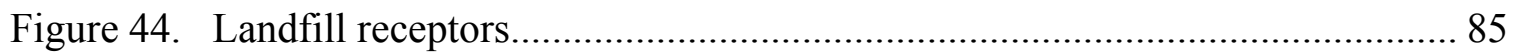

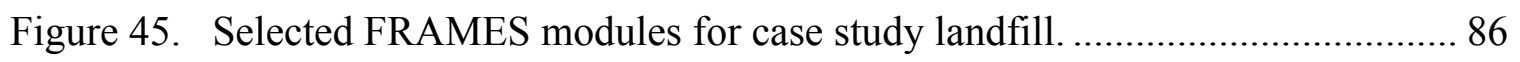

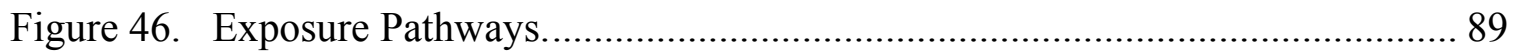

Figure 47. Non Carcinogenic risk vs. concentration by years. .................................. 93

Figure 48. Carcinogenic risk vs. Concentration by years. ....................................... 94

Figure 49. Non Carcinogenic/Carcinogenic risk vs. concentration. ............................. 94

Figure.50. a) Surface plot b) Contour plot of risk vs. mass and Darcy velocity............ 97

Figure 51. a) Surface plot b) Contour plot of risk vs. thickness and Darcy velocity...... 97

Figure 52. a) Surface plot b) Contour plot of risk vs. mass and thickness ................... 98

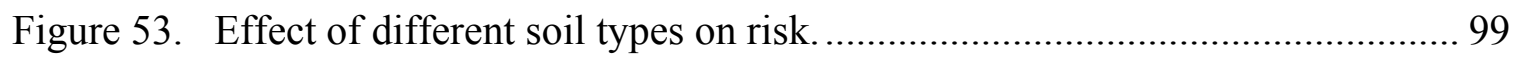

Figure 54. Effect of different soil types on hazard index. ...................................... 99

Figure 55. Common trends in quantity and quality during the PCC of landfill............ 102

Figure 56. Integrated data and knowledge approach to improve data quality............. 103

Figure 57. Monthly total leachate vs. monthly total rainfall................................... 108

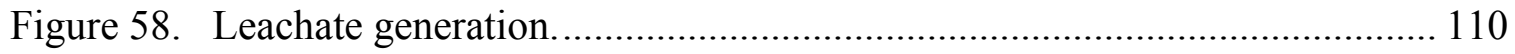

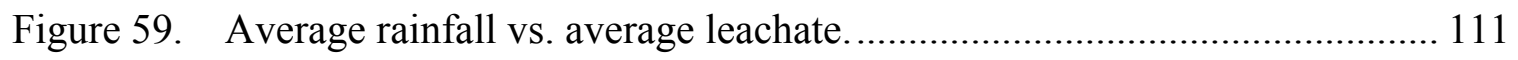

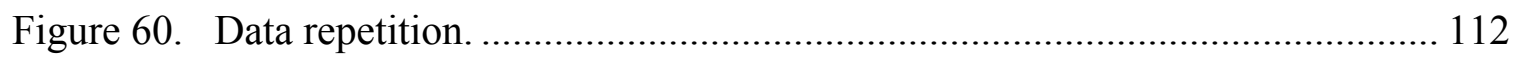

Figure 61. Projected trends for a) vinyl chloride, b) chloride.................................. 116

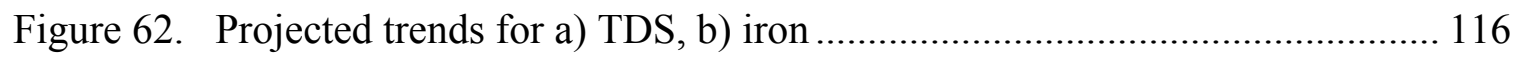




\section{LIST OF ACRONYMS}

ATSDR Agency for Toxic Substances and Disease Registry

BDL Below Detection Limit

BOD Biological Oxygen Demand

BTEX Benzene, Toluene, Ethylbenzene, and Xylenes

CAA Clean Air Act

COD Chemical Oxygen Demand

EG Emission Guidelines

EPA Environmental Protection Agency

EPCC Evaluation of Post Closure Care Methodology

FRAMES Framework for Risk Analysis Multimedia Environmental Systems

HAL Health Advisory Limit

HI Hazard Index

HH\&E Human Health and Environment

LCRS Leachate Collection and Removal System

LFG Landfill Gas

LandGEM Landfill Gas Emissions Model

LFGTE Landfill Gas to Energy

MCL Maximum Contaminant Level

MEPAS Multimedia Environmental Pollutant Assessment System

MSW Municipal Solid Waste

MTBE Methyl-tert-butyl ether 


$\begin{array}{ll}\text { MW } & \text { Monitoring well } \\ \text { ND } & \text { Non-detected } \\ \text { NMOCs } & \text { Nonmethane Organic Compounds } \\ \text { NSPS } & \text { New Source Performance Standards } \\ \text { NTP } & \text { National Toxicology Program } \\ \text { PCC } & \text { Post Closure Care } \\ \text { PE } & \text { Polyethylene } \\ \text { PNNL } & \text { Pacific Northwest National Laboratory } \\ \text { RCRA } & \text { Resource Conservation and Recovery Act } \\ \text { RD\&D } & \text { Research Development \& Demonstration } \\ \text { RP } & \text { Regulated Parameter } \\ \text { VOCs } & \text { Volatile Organic Compounds }\end{array}$




\section{CHAPTER 1}

\section{INTRODUCTION}

Landfills are engineered deposit of waste onto and into land in such a way that pollution or harm to environment is prevented. Landfill is critical to most waste management strategies, because it is the simplest, cheapest and most cost-effective method of disposing of waste. Unfortunately, there are many examples of environmental pollution that have arisen as a result of landfill activities (such as leachate and gas migration). The Resource Conservation Recovery Act (RCRA) in 1979 has changed the solid waste handling approach in the United States. RCRA has created guidelines for siting, construction, operation and monitoring of landfills to make solid waste disposal safe to human health and environment during operational phase of the landfill. Also Subtitle D of RCRA regulates post closure of landfills. Subtitle D requires 30 years post closure period for non-hazardous wastes in landfills. According to solid waste facility regulations codified in 40 CFR $\S 258.61$ (b), the length of the post-closure care period can be extended or shortened by the governing regulatory agency on a site-specific basis. However, the decision to extend or shorten the post closure care period should be based on whether the landfill is a threat to human health or the environment. Incorporation of risk analysis for assessing potential threats to human health and environment during the PCC period will allow more efficient management strategies for closed landfill sites. The use of a scientifically justifiable decision making methodology would also have significant economic benefits and will provide a measure of post closure care (PCC) liability for public understanding. PCC activities under Subtitle D include leachate collection and treatment, groundwater monitoring, inspection and maintenance of the final cover, and monitoring 
to ensure that landfill gas does not migrate off site or into on-site buildings. Methodology for ending PCC includes performance based factors as well as end use considerations for potential threats to human health and the environment. The performance based decision making factors for ending PCC at landfills include:

- Quantification of pollutants originating from landfill (i.e., leachate and landfill gas);

- Evaluation of trends in pollutant levels and quantities at the source;

- Prediction of pollutant levels that may be released from the site and potential impacts to human health and the environment; and

- Projection of future monitoring needs.

Detailed analyses of performance data from Davie landfill can provide scientific basis for the development of a decision making framework that would be suitable for Florida landfills.

\section{OBJECTIVES}

The goal of this dissertation is to explore the applicability of a performance based methodology to Florida landfills with the potential to reduce the extent or duration of PCC and to develop efficient risk assessment method. The specific objectives of the dissertation are:

1. Evaluate post closure performance data from closed Florida landfill cells,

2. Predict pollutant levels and quantities originating from closed landfill cells,

3. Analyze potential threats to human health and the environment based on end use of landfills. 


\section{THE SCOPE OF THE DISSERTATION}

Development of a systematic approach that can be used as a decision making tool to extend or shorten the PCC period or modify frequency of PCC activities should be based on whether the landfill is a threat to human health or the environment. These decisions require technically sound and justifiable methods for analysis and interpretation of available data and information from closed landfill sites. It is important that a set of measurements is developed and used appropriately to evaluate the activity in closed landfills in terms of their overall stability and potential threat to human health or the environment.

Landfill stability depends on a number of factors that include variables that are related to site conditions, and design and operational parameters taking place at the site and the surrounding areas both before and after the closure of a landfill cell. Therefore, PCC decisions should be based on location specific factors, operational factors, design factors, post closure performance and end use. Following is the brief explanation of the steps followed for this study;

- The first step of this dissertation project was to identify time dependent changes in a landfill's structure and components. Davie Landfill (also known as Vista View Park) was selected as a case study landfill. The main reason for selecting this landfill is data availability. Davie Landfill has ample data on leachate quantity and quality, landfill gas, and groundwater monitoring, which plays a key role in PCC duration evaluation. A performance based methodology was used to evaluate the PCC needs of closed Davie Landfill at City of Davie in Broward County, Florida. According to this methodology, landfill leachate quality and quantity data, rainfall 
- The second step of the dissertation project was to conduct a risk analysis in parallel with the system performance parameters to fill in the knowledge gap between design and operational factors and to find the effects of these factors on post closure environmental risks over time. The risk assessment was conducted by using Framework for Risk Analysis Multimedia Environmental Systems (FRAMES) model to analyze the migration pathways and to estimate health risks resulting from the landfill. Several metals and volatile organic compounds were identified as potential contaminants of concern for assessment of health risks due to contaminated groundwater near the Davie Landfill.

- The third step of the study was to identify the challenges which were encountered data collection. According to the identified challenges, some recommendations were made for future studies.

- The last step of the study was to define sustainable management of solid waste landfills by identifying the possible solutions for eliminating waste materials that result in contaminants with longer periods of persistence. 


\section{CHAPTER 2}

\section{BACKGROUND}

\subsection{Landfill}

Landfill has been defined as "The engineered deposit of waste onto and into land in such a way that pollution or harm to environment is prevented and, through restoration, land provided which may be used for another purpose" (Westlake, 1995). Landfill is critical to most waste management strategies, because it is the simplest, cheapest and most cost-effective method of disposing of waste (Allen, 2001). Unfortunately, there are many examples of environmental pollution that have arisen as a result of landfill activities (such as leachate, gas migration) (Westlake, 1995).

Containment refers to controlling waste, leachate, landfill gas, rain and surface water. Caps, covers and liners are the three basic components of a landfill containment system. The landfill capping system reduces the infiltration of precipitation while controlling leachate and gas migration (Bachus, 1995). Landfill gas, originating from the anaerobic biodegradation of the organic content of waste, consists mainly of methane and carbon dioxide, with traces of other volatile organic compounds. Pressure, concentration and temperature gradients that develop within the landfill result in gas emissions to the atmosphere and in lateral migration through the surrounding soils (Nastev, 2001).

The landfill lining system controls and minimizes the release of leachate using a leachate collection system (Bachus, 1995). Leachate, as a chemical substance, takes the constituents of the solid waste mass through which it flows. Leachate quality is a vitally important consideration when leakage through the liner system is concerned because of the groundwater and surface water pollution (Koerner et al., 2000). High leachate 
strength and gas generation may persist long into the future, resulting in the need for long-term management and monitoring of landfills and barrier systems that must function for very long periods of time (Benson, 2007). Failure of one or more landfill components may lead to system failure (Bachus, 1995).

\subsection{Landfill Components}

This section provides role of important design and operational parameters on the post closure performance of closed landfills.

\subsubsection{Leachate Collection System}

Leachate is formed when water passes through the waste in the landfill cell. As the liquid moves through the landfill many organic and inorganic compounds, like heavy metals, are transported into the leachate. The amount of leachate produced is directly linked to the amount of precipitation around the landfill. The amount of liquid waste in the landfill also affects the quantity of leachate produced. Leachate collection systems (LCS) are commonly constructed with layered materials. A LCS mainly consists of the following components as shown in Figure 1.

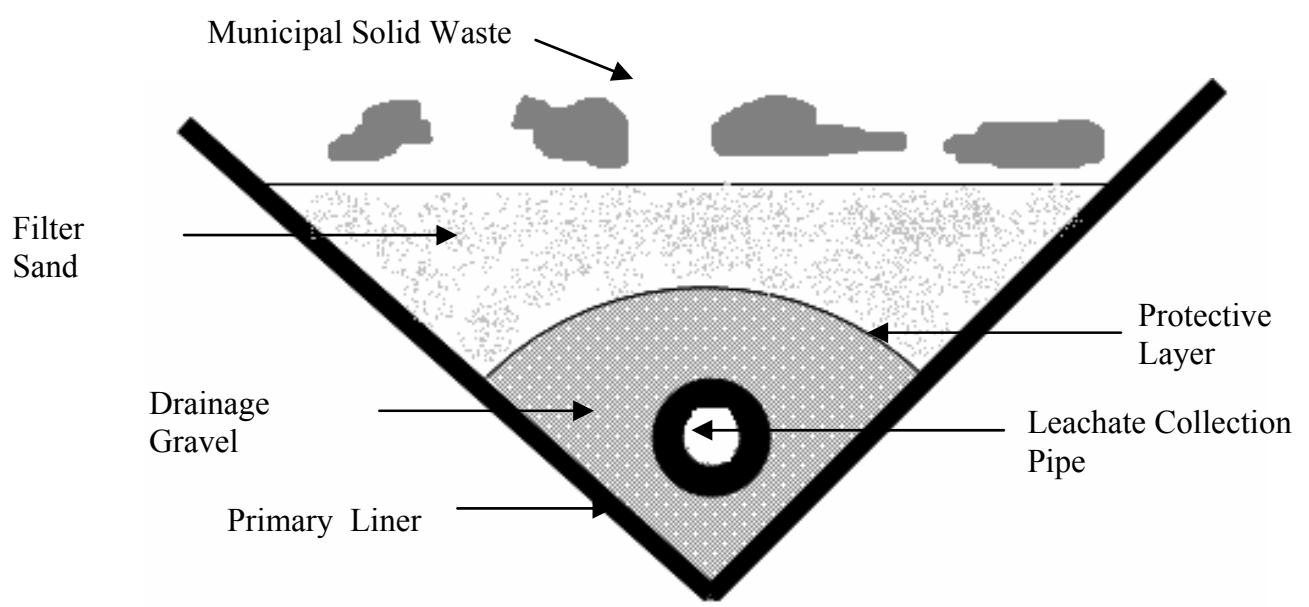

Figure 1. Components of leachate collection systems (adapted from Reinhart, 2000). 
Landfill liners are designed and constructed to create a barrier between the waste and the environment and to drain the leachate to collection and treatment facilities. This is done to prevent the uncontrolled release of leachate into the environment. Liners may be described as single, composite, or double liners. Single liners consist of a clay liner, a geosynthetic clay liner, or a geomembrane. Composite liner systems consist of a geomembrane in combination with a clay liner and are required in municipal solid waste (MSW) landfills. The double liner systems consist of either two single liners, two composite liners, or a single and a composite liner. Double-liner systems are used in some municipal solid waste landfills and in all hazardous waste landfills.

\subsubsection{Gas Collection System}

Fifty percent of the municipal solid waste in the landfill site which consists of biodegradable organics gets broken down by bacteria for energy. This is done by aerobic or anaerobic fermentation. The degradable organic matter gets broken down into a stabilized organic residue (or compost), and water and carbon dioxide, the latter contributing to the composition of landfill gas.

Landfill owner/operators are required to collect landfill gas to prevent exposure of humans to the gas and to avoid explosive danger. Landfill gas at the site can be collected in two ways: passive gas collection systems and active gas collection system. Passive gas

collection systems facilitate collection of gas under gas pressure and concentrations inside the landfill. Active gas collection systems use pumps or vacuum to extract the gas using collection wells. Once gas is collected it can be carried to a flare or converted to energy. 


\subsubsection{Cap}

A cover or cap is an umbrella over the landfill to keep water out (to prevent leachate formation). It will generally consist of several sloped layers: clay or membrane liner (to prevent rain from intruding), overlain by a very permeable layer of sandy or gravelly soil (to promote rain runoff), overlain by topsoil in which vegetation can root (to stabilize the underlying layers of the cover). If the cover (cap) is not maintained, rain will enter the landfill resulting in buildup of leachate to the point where the bathtub overflows its sides and wastes enter the environment.

\subsubsection{End Use}

There are two types of end use for closed landfills shown in Table 1.

- Passive uses such as Green Space, Wildlife or Nature Conservancy and hiking trails.

- Active uses such as sports fields, golf courses, industrial uses and transfer stations.

Table 1. Land use examples of closed landfills (Waste Management 2008)

\begin{tabular}{|l|}
\hline \multicolumn{1}{|c|}{ Land Uses } \\
\hline BMX Race Track, Model Airplane Field, Little League Baseball Facility, Soccer fields, \\
tennis courts, boat launch, fishing area, amphitheater, sledding area (Waterford \\
Township, PA, Denver Landfill, CO) \\
\hline Salt water sailing lake, wetlands, levees, amphitheater, \& wildlife refuge \\
(GROWS/Tully town Landfills in Falls Township, PA, Altamont Landfill in Livermore \\
CA, American Landfilli n Waynesburg, OH) \\
\hline Recreation park, wildlife refuge and butterfly garden (Kirby Canyon landfill, CA) \\
\hline Business Park and Golf Course, Ski Slopes (Chicago, IL) \\
\hline Public Works Storage Facility and Transfer Station (Naperville Landfill, IL) \\
\hline
\end{tabular}

\subsection{Post Closure Care Of Landfills}

Subtitle D of RCRA requires 30 years post closure period for non-hazardous wastes in landfills. Post closure care (PCC) activities under Subtitle D include leachate collection and treatment, groundwater monitoring, inspection and maintenance of the 
final cover, and monitoring landfill gas. According to solid waste facility regulations codified in 40 CFR $\$ 258.61(\mathrm{~b})$, the 30 year PCC period specified by Subtitle D can be extended or shortened by governing regulatory agency on a site-specific basis such as whether the landfill is a threat to human health or the environment. Methodology for ending the PCC period for municipal solid waste (MSW) landfills should include performance based factors. The performance based decision making factors for ending PCC at landfills include (Morris, 2005):

- Quantification of pollution (i.e., leachate and landfill gas);

- Definition of trends in concentrations and quantities at the source;

- Evaluation and prediction of the release of constituents for potential impacts to human health and the environment; and

- Monitoring to confirm evaluations or predictions.

Landfills are engineered systems which should be developed with a scientific approach to designing, operating and closing in a way to optimize the post closure care (PCC) costs. A closed landfill site can be reused for many purposes which serve the community needs (Vesilind et al., 2001; Tansel, 1998). Post closure care needs for MSW landfills include ground water and gas monitoring, leachate collection and treatment, gas recovery and management, and final cover maintenance (Vesilind et al., 2001; Reinhart et al., 1997). Waste characteristics, climate, landfill design, and closure methods affect the rate and duration of leachate and gas production from a closed MSW landfill site. RCRA rules require landfill owners to prove that they have funds to maintain their landfills after closure and correct any environmental problems the landfill may cause. Issues that need to be incorporated into the financial assurance aspects of RCRA for MSW landfills 
should also include the duration of post closure care, the amount of funding needed for future long-term care, financial assurances, and mechanisms to ensure that funds will be available exclusively for post closure care and, if needed, ground water remediation (Lee, 2003; Anderson, 2004; Caldwell, 2004). In a landfill, when the moisture content of the waste is reduced to about $20 \%$, rate of gas production significantly slows (Christensen et al., 1989). With a good cap system, it is possible to limit the moisture supply to a landfill. Over time, the cap system may lose its integrity due to environmental and geotechnical stresses. Consequently, the cap requires periodic maintenance to prevent excessive amounts of moisture from entering the waste (Lee et al., 1993; Lee 2004). The implication that monitoring will be discontinued after 30 years because the landfill is stable and no longer represents a threat to the environment requires a scientific and systematic approach for monitoring performance of closed landfills (Barlaz, 2004; Barlaz et al., 2002). By implementing proper engineering measures during the operation of a landfill, the stabilization period of the MSW can be reduced significantly. Florida's climate promotes waste decomposition significantly faster than landfills located in other parts of the United States with dryer conditions. Detailed analyses of performance data from case study landfills will allow development of a decision making framework suitable for Florida landfills and help quantify and compare the extent of stabilization being achieved over time

\subsection{Requirements for Post Closure Care (PCC)}

The Resource Conservation Recovery Act (RCRA) Subtitle D regulates waste disposal and handling for non-hazardous waste. Closure and post closure care requirements are identified in $40 \mathrm{CFR} \S 258.60$ and $40 \mathrm{CFR} \S 258.61$, respectively, in 
Subpart F of Subtitle D. Post closure care requirements under 40 CFR $\$ 258.61$ are as follows;

“(a) Following closure of each MSWLF unit, the owner or operator must conduct post closure care. Post closure care must be conducted for 30 years, except as provided under paragraph (b) of this section, and consist of at least the following:

(1) Maintaining the integrity and effectiveness of any final cover, including making repairs to the cover as necessary to correct the effects of settlement, subsidence, erosion, or other events, and preventing run-on and runoff from eroding or otherwise damaging the final cover;

(2) Maintaining and operating the leachate collection system in accordance with the requirements in $\$ 258.40$, if applicable. The Director of an approved State may allow the owner or operator to stop managing leachate if the owner or operator demonstrates that leachate no longer poses a threat to human health and the environment;

(3) Monitoring the ground water in accordance with the requirements of Subpart E of this part and maintaining the ground-water monitoring system, if applicable; and (4) Maintaining and operating the gas monitoring system in accordance with the Subpart C operating criteria under $\$ 258.23$.

(b) The length of the post closure care period may be:

(1) Decreased by the Director of an approved State if the owner or operator demonstrates that the reduced period is sufficient to protect human health and the environment and this demonstration is approved by the Director of an approved State; or 
(2) Increased by the Director of an approved State if the Director of an approved

State determines that the lengthened period is necessary to protect human health and the environment."

PCC begins when the landfill is closed. During the PCC period, landfill owner/operators are required to monitor for leachate, landfill gas, and ground-water and maintain integrity of cap so that the landfill does not pose any threat to surrounding human health and environment (HH\&E). Post closure care activities are described below. When the final cover is installed, repairs and maintenance may be necessary to keep the cover in good working order. Maintenance may include inspection, testing, and cleaning of leachate collection and removal system pipes, repairs of final cover, and repairs of gas and ground-water monitoring networks. Inspections should be made on a routine basis. (USEPA, 1993)

\subsubsection{Leachate Collection and Removal System (LCRS)}

Owner or operators of landfill are required to collect and remove leachate collected by leachate collection systems. LCRS monitoring and maintenance activities include maintaining and repairing pump stations, meters, and valves, manholes, pipes, may be flushing and pressure cleaning on regular schedule (i.e., annually) to reduce the accumulation of sediments, precipitation and to prevent biological fouling in leachate collection and removal pipes and sampling and analysis of leachate on regular basis. (RCRA Subtitle D, Subpart F).

\subsubsection{Groundwater Monitoring Systems}

The impact of leachate and landfill gas on groundwater should be identified by performing groundwater monitoring. Groundwater monitoring samples are analyzed and 
compared to background conditions or health-based drinking water standards. (RCRA Subtitle D, Subpart F).

\subsubsection{Gas Monitoring System}

Monitoring of landfill gas at the property boundary and in on-site structures, operation and maintenance of the landfill gas extraction system is required (if such a system exists). Most large modern landfills are required to operate such a system to comply with the New Source Performance Standards (NSPS) under the Clean Air Act (CAA). Gas monitoring also involves upgrades or repairs to landfill gas management system components; mitigation of off-site gas migration concerns. Vents should be checked to ensure they are not clogged by foreign matter such as rocks. If not working properly, the gas collection systems should be flushed and pressure-cleaned. (RCRA Subtitle D, Subpart F).

\subsubsection{Cover system}

Cap maintenance is performed regularly to preserve the integrity of the landfill final cover. Inspections are usually performed to detect eroded banks, patches of dead vegetation, animal burrows, subsidence and cracks on the cover. Regular mowing of vegetation must be performed at least twice a year. Depending of the condition on cap, owner/operators are required to perform repairs to maintain the cap integrity. (RCRA Subtitle D, Subpart F).

\subsection{Landfill Stabilization Process}

The 30 year post closure monitoring period presumes that at the end of the period, landfill will be stable and will no longer require intensive monitoring. The threats imposed by landfills after closure depend on the extent of degradation of waste occurring 
inside the landfill. The stability of waste refers to the phase of the waste such that it poses no threat to HH\&E. When refuse is buried in a landfill, complex biological and chemical reactions occur as the refuse decomposes. Landfills undergo at least four phases of decomposition, (1) an initial aerobic phase, (2) an anaerobic acid phase, (3) an initial methanogenic phase, and (4) a stable methanogenic phase (Christensen et al., 1995). Recently, an additional aerobic or humic phase of decomposition has been observed (Christensen et al., 1995; Bozkurt et al., 2000). Once the refuse is very well decomposed, the rate of oxygen diffusion into the landfill may exceed the rate of microbial oxygen depletion. Thus, over time the anaerobic landfill is hypothesized to become an aerobic ecosystem. As refuse is buried in landfills over many years in a series of cells and lifts, it is quite common for different parts of the landfill to be in different phases of decomposition (Kjeldsen et al., 2002). Most commonly used indicator parameters and their range in different phases is shown in Table 2.

I. Initial aerobic phase: During the initial aerobic phase, oxygen present in the void spaces of the freshly buried refuse is rapidly consumed, resulting in the production of $\mathrm{CO}_{2}$ and maybe an increase in waste temperature

II. An anaerobic acid phase: As oxygen sources are depleted, the waste becomes anaerobic, which supports fermentation reactions. Biodegradable compounds (i.e., cellulose and hemicelluloses) decompose to methane and carbon dioxide in landfills under anaerobic conditions. The highest BOD and COD concentrations in the leachate can be measured during this phase. 
Table 2. Leachate and gas composition at different phases (Tansel et al., 2008; Reinhart et al.,1997).

\begin{tabular}{|l|c|c|c|c|}
\hline Leachate/Gas & $\begin{array}{c}\text { Transition } \\
\text { phase } \\
\mathbf{( 0 - 1 0 0} \text { days })\end{array}$ & $\begin{array}{c}\text { Acid formation } \\
\text { phase } \\
\mathbf{( 1 0 0 - 2 0 0} \text { days })\end{array}$ & $\begin{array}{c}\text { Methane } \\
\text { fermentation } \\
\text { phase } \\
(\mathbf{2 0 0 - 6 0 0} \text { days })\end{array}$ & $\begin{array}{c}\text { Final } \\
\text { maturation } \\
\text { phase } \\
\mathbf{( 6 0 0 -}\end{array}$ \\
\hline $\mathrm{BOD}_{5}$ & $100-10,900$ & $1000-57,700$ & $600-3,400$ & $4-120$ \\
\hline $\mathrm{COD}$ & $480-18,000$ & $1,500-71,100$ & $580-9,760$ & $31-900$ \\
\hline $\mathrm{BOD}_{5}: \mathrm{COD}$ & $0.23-0.87$ & $0.4-0.8$ & $0.17-0.64$ & $0.02-0.13$ \\
\hline $\mathrm{NH}_{3}-\mathrm{N}$ & $120-125$ & $2-1,030$ & $6-430$ & $6-430$ \\
\hline $\mathrm{TKN}$ & $180-860$ & $14-7,970$ & $25-82$ & $7-490$ \\
\hline pH & 6.7 & $4.7-7.7$ & $6.3-8.8$ & $7.1-8.8$ \\
\hline Sulfate & $10-458$ & $10-3240$ & Absent & $5-40$ \\
\hline ORP & +40 to -80 & +80 to -240 & -70 to -240 & +97 to +163 \\
\hline Sulfide & Absent & $0-818$ & 0.9 & Absent \\
\hline Chloride & $30-5,000$ & $30-5,000$ & $30-5,000$ & $30-5,000$ \\
\hline Methane & Absent & Very low & $30-60 \%$ & $0-<10 \%$ \\
\hline Carbon dioxide & $0-10$ & $10-30$ & $30-60$ & $<40$ \\
\hline Oxygen & 20 & $0-5$ & $0-5$ & $>5$ \\
\hline Hydrogen & Absent & $0-2$ & $<0.1$ & $0-2$ \\
\hline
\end{tabular}

III. An initial methanogenic phase: Initial methanogenic phase occurs when measurable quantities of methane are produced. During this phase the acids that accumulated in the acid phase are converted to methane and carbon dioxide by methanogenic bacteria, and the methane production rate will increase (Christensen et al, 1989, Barlaz et al., 1989). COD and BOD concentrations decrease and the $\mathrm{pH}$ increases as acids are consumed.

IV. A stable methanogenic phase: The methane production rate reaches its maximum, and decreases thereafter soluble substrate (carboxylic acids) decreases. In this phase, the rate of $\mathrm{CH} 4$ production is dependent on the rate of cellulose and hemicellulose hydrolysis. The BOD: COD ratio will be below 0.1 in this phase. Leachate and gas characteristics can help in phase identification of MSW. 


\subsection{Landfill Leachate Compositions}

Contaminants found in MSW landfill leachate can be divided into four groups:

I. Dissolved organic matter, quantified as Chemical Oxygen Demand (COD) or Total Organic Carbon (TOC), volatile fatty acids (that accumulate during the acid phase of the waste stabilization, (Christensen et al., 1989) and more refractory compounds such as fulvic-like and humic-like compounds.

II. Inorganic macrocomponents: Calcium $\left(\mathrm{Ca}^{2+}\right)$, magnesium $\left(\mathrm{Mg}^{2+}\right)$, sodium $\left(\mathrm{Na}^{+}\right)$, potassium $\left(\mathrm{K}^{+}\right)$, ammonium $\left(\mathrm{NH}_{4}^{+}\right)$, iron $\left(\mathrm{Fe}^{2+}\right)$, manganese $\left(\mathrm{Mn}^{2+}\right)$, chloride $\left(\mathrm{Cl}^{-}\right)$, sulfate $\left(\mathrm{SO}_{4}{ }^{2-}\right)$ and hydrogen carbonate $\left(\mathrm{HCO}_{3}^{-}\right)$.

III. Heavy metals: Cadmium $\left(\mathrm{Cd}^{2+}\right)$, chromium $\left(\mathrm{Cr}^{3+}\right)$, copper $\left(\mathrm{Cu}^{2+}\right)$, lead $\left(\mathrm{Pb}^{2+}\right)$, nickel $\left(\mathrm{Ni}^{2+}\right)$ and $\operatorname{zinc}\left(\mathrm{Zn}^{2+}\right)$.

IV. Xenobiotic organic compounds (XOCs) originating from household or industrial chemicals and present in relatively low concentrations (usually less than $1 \mathrm{mg} / \mathrm{l}$ of individual compounds). These compounds include among others a variety of aromatic hydrocarbons, phenols, chlorinated aliphatics, pesticides, and plastizers (Kjeldsen et al., 2002).

\subsection{Landfill Gas Composition}

Landfill gas (LFG) is produced as a result of microbial anaerobic decomposition Typical constituents of LFG on a dry volume basis are: methane (45-60\%), $\mathrm{CO}_{2}(40-$ $60 \%)$, nitrogen $(2-5 \%)$, and oxygen $(0.1-1 \%)$; trace gases such as sulfides, disulfides and mercaptans $(0-1 \%)$, ammonia (0.1-1\%), hydrogen $(0-0.2 \%)$, and CO $(0-0.2 \%)$; and other trace non-methane organic compounds (NMOC) such as acetone, benzene, chloroform, dichloromethane, and toluene which are present in concentrations of up to $600 \mathrm{ppmv}$ 
(Tchobanoglous, et al.,1993; Deipser et al., 1994). Gas production from landfills is a function of the nature of the waste, moisture content, $\mathrm{pH}$, temperature and the presence of nutrients (Farquhar et al., 1973). The composition and quantity of gas change with the age of the landfill. During the aerobic phase the dominant gas produced is carbon dioxide. As conditions become anaerobic and methanogenic activities initiate, methane appears.

\subsection{Risk Assessment}

A risk assessment is an analysis that uses information about toxic substances at a site to estimate a theoretical level of risk for people who might be exposed to these substances. The information comes from scientific studies and environmental data from a site. The U.S. Environmental Protection Agency (EPA) has developed risk assessment procedures in order to address the public health concerns and to ensure that Superfund response actions limit the concentration of hazardous substances in the environment to avoid unacceptable risks to human health (USEPA 1986 a-f). A risk assessment provides a comprehensive scientific estimate of risk to persons who could be exposed to hazardous materials present at a site. Risk assessments may focus on chronic, long-term exposures and/or evaluation of acute exposures that may require an emergency response. They are often conducted using a triage approach, beginning with a screening-level assessment to determine if a more comprehensive assessment is necessary (USEPA, 1988b, 1996a, 1999a, 2001b, 2002k).

Quantitative risk assessment has received increased attention because of the recognition of both the potential threat to human health from hazardous substances and the potential for the releases of hazardous substances into environment (Zamuda, 1989). 
The primary application of quantitative risk assessment in the U.S EPA Superfund program is to evaluate the potential risk posed at each National Priorities List (NPL) facility, so that the appropriate remedial alternative can be identified (Paustenbach, 1988). The U.S EPA uses a risk based evaluation method, The Hazard Ranking System (HRS), to identify uncontrolled and abandoned hazardous waste sites falling under Superfund programs. The HRS allows the selection or rejection of a site for placement on the U.S EPA NPL: it is used for prioritizing sites so that those posing the greatest risks receive quicker response. Another application of risk assessment is in the selection of appropriate sites for hazardous waste facilities; sites are ranked for their appropriateness for stipulated purposes according the levels of risk that each potentially poses under different scenarios (Asante- Duah, 1993).

\subsubsection{Landfill Risk Assessment}

Risk assessment is a recent (LaGoy, 1994) and growing field of study (Tweeds, 1996). Landfills continue to be one of the main methods of waste disposal despite their relatively high potential to pollute the environment. Therefore, risk assessment and management is an effective management tool for protecting the environment against landfills' hazards. On the other hand, there is no holistic risk assessment methodology, and neither is holistic knowledge-based computer model, which could perform the process of risk assessment for landfills from start (i.e., baseline study) through to the end (Butta et al., 2003; Butta, 2007).

\subsubsection{Computer Aided Landfill Risk Assessment Approaches}

The development of computational methods and the ability to model systems more precisely enables hazards to be quantified, their effects to be simulated and risk 
analysis to be pursued with greater accuracy, leading to a more effective risk management (Butta, 2007). Some computer-aided landfill risk assessment modelings are explained below.

3MRA: The Multimedia, Multi-pathway, Multi-receptor Exposure and Risk Assessment (3MRA) starts with a waste stream concentration in a waste management unit (landfill, waste pile, aerated tank, surface impoundment, or land application unit), estimates the release and transport of the chemical throughout the environment, and predicts associated exposure and risk. Using a feed-forward approach, 3MRA simulates multimedia (air, water, soil, sediments), fate and transport, multi-pathway exposure routes (food ingestion, water ingestion, soil ingestion, air inhalation, etc.), multi-receptor exposures (resident, gardener, farmer, fisher, ecological habitats and populations; all with various cohort considerations), and resulting risk (human cancer and non-cancer effects, ecological population and community effects) (Babendreier et al., 2005).

HELP: The Hydrologic Evaluation of Landfill Performance (HELP) computer program is a quasi-two-dimensional hydrologic model of water movement across, into, through and out of landfills. The program was developed to conduct water balance analysis of landfills, cover systems, and solid waste disposal and containment facilities. As such, the model facilitates rapid estimation of the amounts of runoff, evapotranspiration, drainage, leachate collection, and liner leakage that may be expected to result from the operation of a wide variety of landfill designs. The primary purpose of the model is to assist in the comparison of design alternatives as judged by their water balances. The model, applicable to open, partially closed, and fully closed sites, (Schroeder et al., 1994). HELP program contains only some aspects of landfill risk assessment. These are mainly the 
design features of landfill (such as liners, capping) and some of the baseline study aspects (such as precipitation, surface runoff), while not addressing many other RA modules and sub-modules. (Butta, 2007)

GASSIM: The software GasSim, although dealing with relevant risk assessment modules, including gas generation, migration, impact and exposure, as the name GasSim suggests, is designed for assessing landfill gas and not for leachate (Butta,2007).

CONSIM: The ConSim program is a tool for assessing the risks that are posed to groundwater quality by pollutants migrating from contaminated land (Whittaker et al., 2001).

ARAMS: Adaptable risk assessment modeling system (ARAMS) is a computer-based, modeling and database driven analysis system developed for the US Army for estimating the human and ecological health impacts and risk associated with military relevant compounds (MRCs) and other constituents (ERDC, 2006).

FRAMES: Framework for Risk Analysis Multimedia Environmental Systems (FRAMES) is a software platform for selecting and implementing environmental software models for risk assessment and management problems (Evangelidis, 2003). FRAMES works with Multimedia Environmental Pollutant Assessment System (MEPAS) modules which integrates transport and exposure pathways for chemical releases to determine their potential impact on the environment, individuals, and populations (http://mepas.pnl.gov/mepas/index.stm). The system has wide applicability to a range environmental problems using air, groundwater, surface water, overland, and exposure models" (Whelan et al., 1992). 


\subsubsection{Selection of Best Approach For Landfill Risk Assessment}

After reviewing available computer-aided landfill risk assessment software, the most suitable program for landfill risk assessment was tried to identify based on the results of decision tree shown in Table 3.

Table 3. Decision tree for best approach of landfill risk assessment.

\begin{tabular}{|c|c|c|c|}
\hline Program & Advantage & Disadvantage & Suitability \\
\hline 3MRA & $\begin{array}{l}\text { Covers risk assessment of } \\
\text { landfill. } \\
\text { Available for free. }\end{array}$ & $\begin{array}{l}\text { Does not include complete } \\
\text { set of exposure routes. } \\
\text { Complicated. }\end{array}$ & Yes \\
\hline HELP & $\begin{array}{l}\text { Covers landfill design by } \\
\text { modeling. } \\
\text { Available for free }\end{array}$ & $\begin{array}{l}\text { Does not cover risk } \\
\text { assessment. }\end{array}$ & No \\
\hline GASSIM & $\begin{array}{l}\text { Covers assessment of risk } \\
\text { resulted by landfill gas. }\end{array}$ & $\begin{array}{l}\text { Designed for a risk } \\
\text { assessment of landfill gas. } \\
\text { Commercially available }\end{array}$ & No \\
\hline$\underline{\text { CONSIM }}$ & $\begin{array}{l}\text { Covers assessment of risk } \\
\text { resulted by GW pollution } \\
\text { by contaminated land. }\end{array}$ & $\begin{array}{l}\text { Designed for a risk } \\
\text { assessment of GW pollution } \\
\text { Commercially available }\end{array}$ & No \\
\hline$\underline{\text { ARAMS }}$ & $\begin{array}{l}\text { Covers health impacts of } \\
\text { contaminated media. } \\
\text { Available for free }\end{array}$ & $\begin{array}{l}\text { Relies on another computer } \\
\text { program (FRAMES). } \\
\text { Does not have geology, } \\
\text { hydrology section, etc. }\end{array}$ & No \\
\hline FRAMES & $\begin{array}{l}\text { Covers risk assessment of } \\
\text { contaminated media. } \\
\text { Available for free. }\end{array}$ & $\begin{array}{l}\text { Does not present an overall } \\
\text { risk assessment methodology } \\
\text { for landfill }\end{array}$ & Yes \\
\hline
\end{tabular}

According to decision tree the most suitable risk assessment programs were 3MRA and FRAMES models. Between these two models, 3MRA was more complicated and does not cover exposure routes to calculate health risk. Therefore FRAMES model was chosen to analyze health effect of parameters resulted from landfill to surrounding area. 


\section{CHAPTER 3}

\section{METHODOLOGY}

Development of a systematic approach which can be used as a decision making tool to extend or shorten the PCC period or modify frequency of PCC activities should be based on whether the landfill is a threat to human health or the environment. These decisions require technically sound and justifiable methods for analysis and interpretation of available data and information from closed landfill sites. It is important that a set of measurements is developed and used appropriately to evaluate the activity in closed landfills in terms of their overall stability and potential threat to human health or the environment. The general approach for development of a PCC period decision is presented in Figure 2.

PCC Period Decision Approach

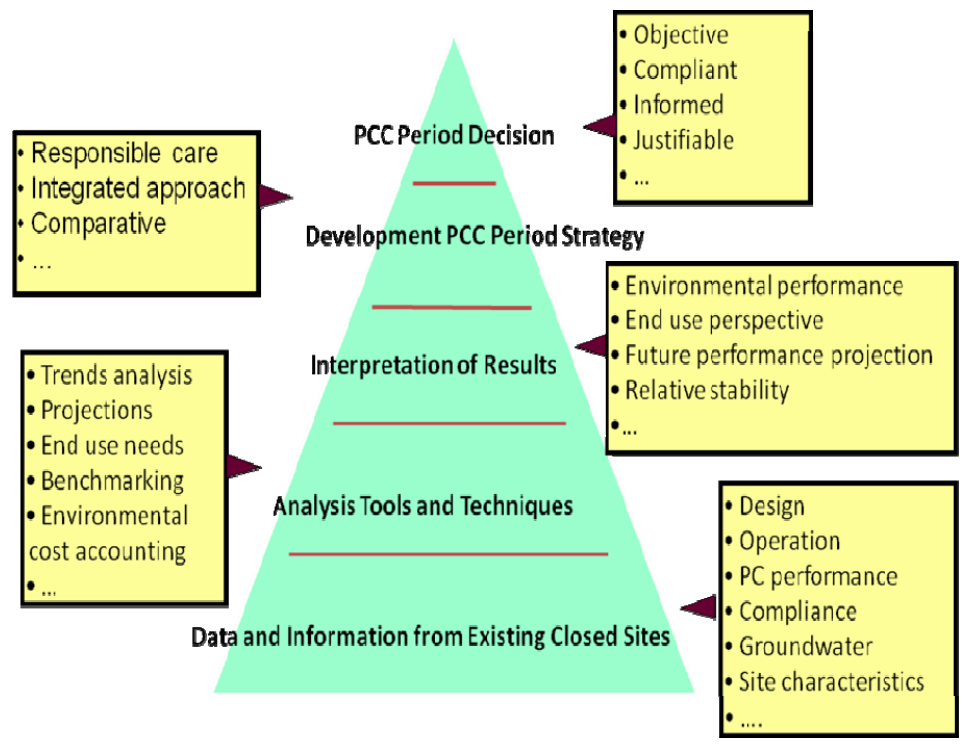

Figure 2. General approach and methodology for PCC period decision.

Landfill stability depends on a number of factors which include variables that are related to site conditions, and design and operational parameters taking place at the site and 
the surrounding areas both before and after the closure of a landfill cell. Therefore, PCC decisions should be based on location specific factors, operational factors, design factors, post closure performance, end use, and economic factors shown in Figure 3.

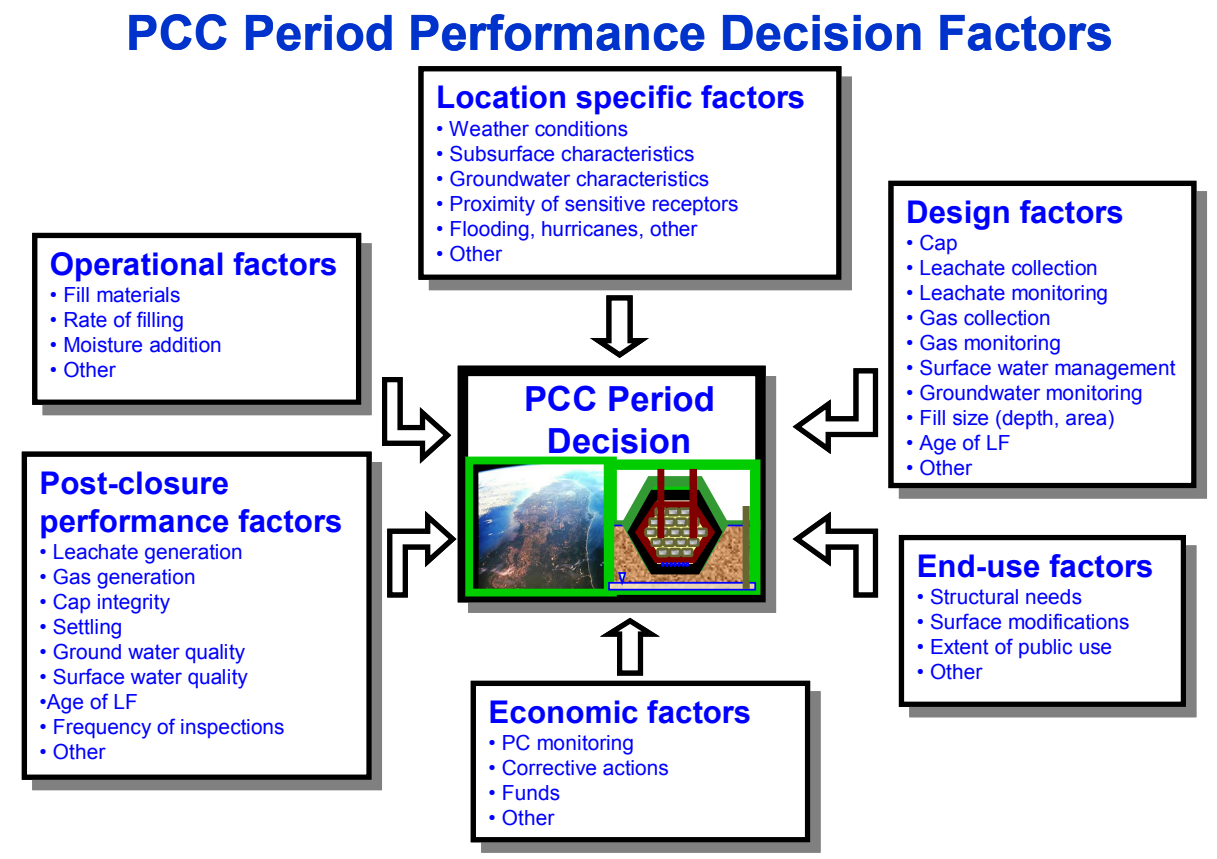

Figure 3. Examples of potential decision factors for PCC period.

A performance based methodology was used to evaluate the PCC needs for closed Davie Landfill at City of Davie in Broward County. The data used for the Davie Landfill were provided by Broward County Waste and Recycling Services Solid Waste Operations Division. According to this methodology, landfill leachate quality and quantity data, rainfall data, landfill gas composition and quantity data, groundwater quality monitoring data, and cap integrity were evaluated to forecast the level of stability of the case study landfills. The purpose of the risk analysis is to analyze the migration pathways and to estimate health risks resulting from the landfill. The risk assessment was conducted by using Framework for Risk Analysis Multimedia Environmental Systems (FRAMES) model. For each landfill, 
several metals and volatile organic compounds were identified as potential contaminants of concern for assessment of health risks due to contaminated groundwater near the case study landfills. Figure 4 presents, the sequence of specific task followed during the project.

\section{PCC Period Assessment Tasks}

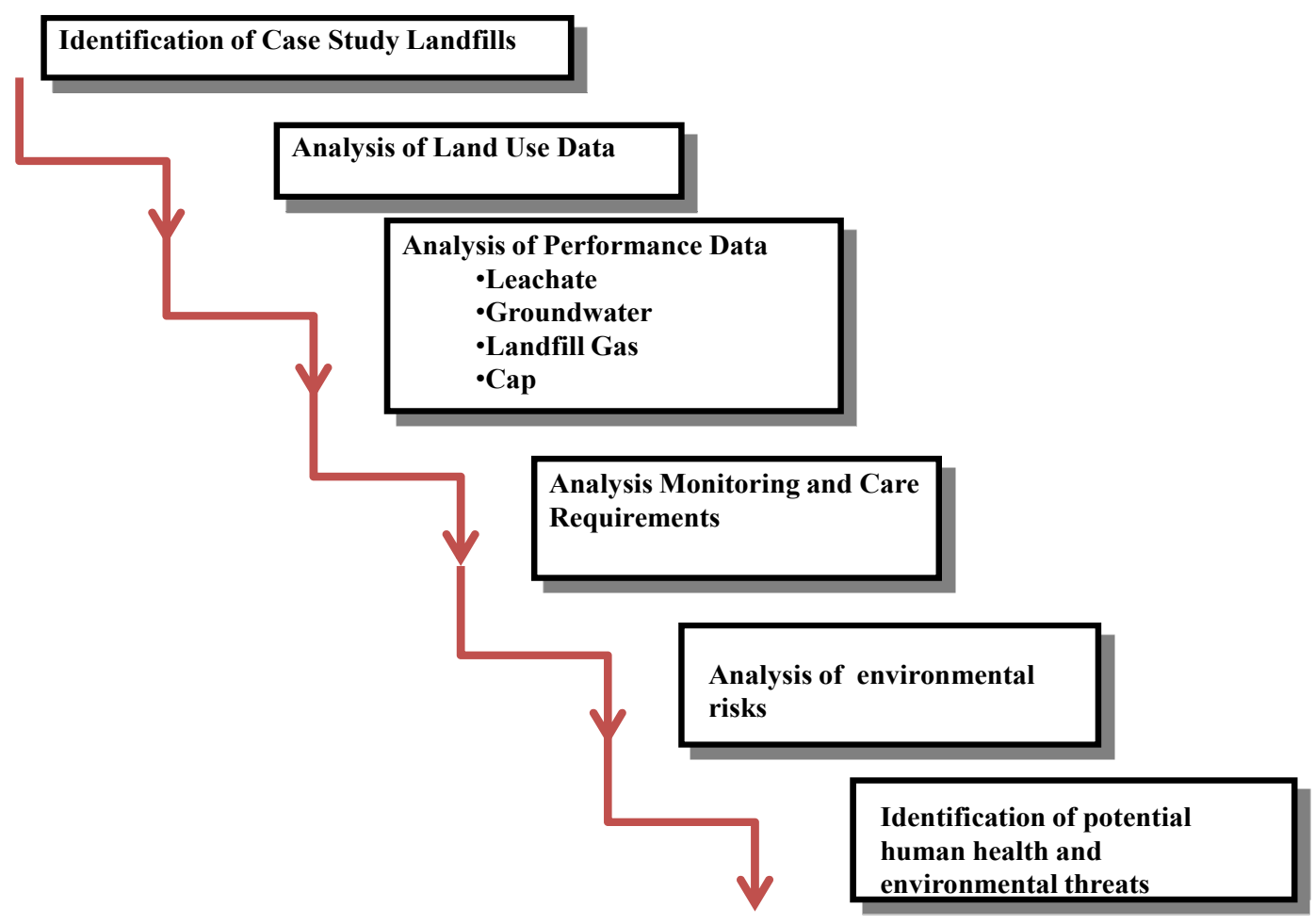

Figure 4. PCC Period assessment task sequence.

\subsection{Performance Based Methodology}

For this study performance based methodology was used to evaluate the case study landfill based on the data and information available about the site. The approach and analysis details of the methodology used are described below.

The PCC duration for modern landfills is 30 years. The duration of PCC can be reduced by the director of an approved State if an owner/operator of a landfill 
demonstrates that the landfill exhibits no threat to the surrounding HH\&E or can be increased if the director of the approved State determines that an increased PCC period is required for the protection of HH\&E. RCRA provides flexibility in optimizing PCC duration of landfills, although it does not identify the criteria/methodology which can be used in demonstrating the status of a landfill from the point of PCC. The performance based methodology is designed for evaluation of post closure care (PCC) duration and activities for modern landfills. The performance based PCC decision system developed by Geosyntec Consultants was used for the assessment of site conditions to project PCC needs

The PCC methodology is divided into four modules and this categorization is based on the classification of PCC activities as directed by RCRA shown in Figure 5. These modules are:

(a) Leachate module

(b) Landfill gas module

(c) Groundwater module and

(d) Cap module.

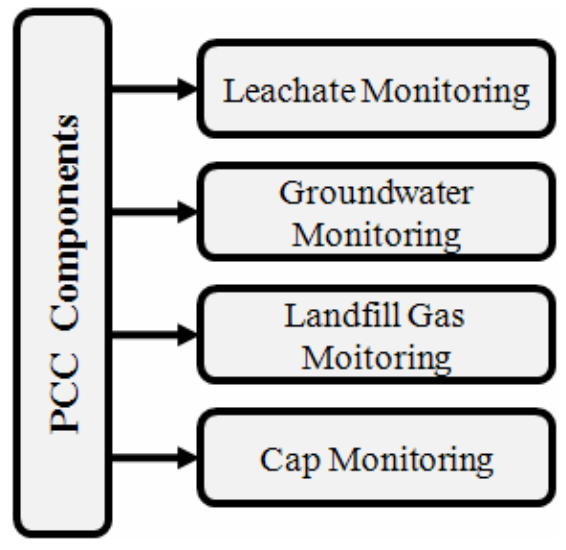

Figure 5. PCC components.

To define the trends in leachate and landfill gas two different trend analysis methods used. These are,

- Time Series Decomposition Method for leachate trend

- Landfill Gas Emission Model (LandGEM) 


\subsubsection{Trend Analysis Time Series Decomposition Method}

The trend analysis of data from the case study landfill was defined by time series decomposition method using MINITAB 15 software. The technique gives the best results for the data on which clear seasonal effect can be seen. The decomposition separates the times series into linear trend and seasonal components, as well as error, and provide forecasts. It can be chosen whether the seasonal component is additive or multiplicative with the trend shown in Table 4.

Table 4. The features of Additive and Multiplicative models.

\section{Decomposition, Multiplicative Model is used}

- data with either no trend or constant trend,

- data with constant seasonal pattern

- size of seasonal pattern proportional to data

- long range forecasting

Forecast profile:

straight line multiplied by seasonal pattern

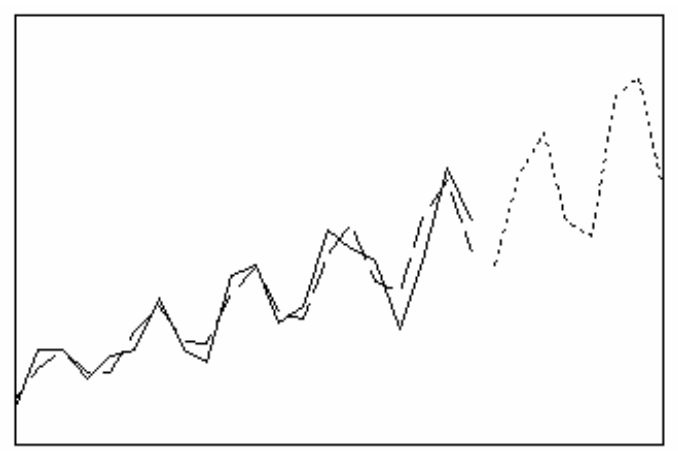

\section{Decomposition, Additive Model is used}

- data with either no trend or constant trend,

- data with constant seasonal pattern

- size of seasonal pattern not proportional to data

- long range forecasting

Forecast profile:

straight line with seasonal pattern added

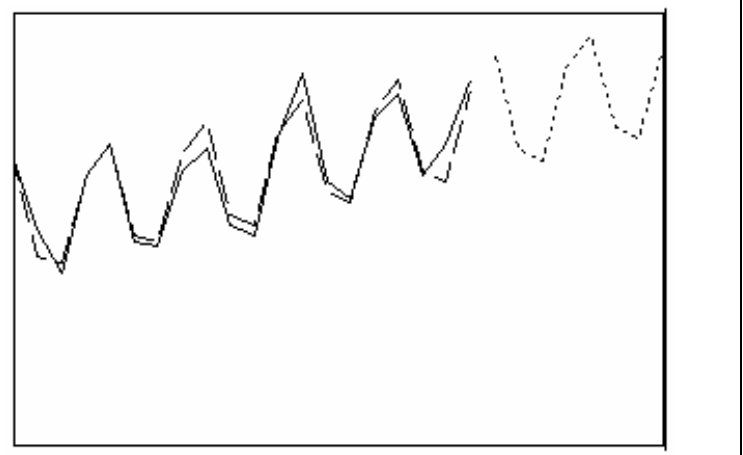

For the additive model, forecasts can be made by the following model

$\mathrm{Y}_{\mathrm{t}}=$ Trend + Seasonal + Error

For the multiplicative model, forecasts can be made by the following model

$\mathrm{Y}=$ Trend $\mathrm{x}$ Seasonal $\mathrm{x}$ Error

Where, $\mathrm{Y}$ is the observation at time $\mathrm{t}$. 
Decomposition involves the following steps:

1. Smoothes the data using a centered moving average with a length equal to the length of the seasonal cycle. When the seasonal cycle length is an even number, a two-step moving average is required to synchronize the moving average correctly.

2. Divides the moving average into (multiplicative model) or subtracts it from (additive model) the data to obtain what are often referred to as raw seasonal values.

3. Determines the median of the raw seasonal values.

4. Adjusts the medians of the raw seasonal values so that their average is one (multiplicative model) or zero (additive model). These adjusted medians constitute the seasonal indices.

5. Uses the seasonal indices to seasonally adjust the data.

6. Fits a trend line to the seasonally adjusted data using least squares regression.

Table 5. Methods for determining the accuracy of the time series analysis

\begin{tabular}{|c|c|c|}
\hline $\begin{array}{c}\text { Mean Absolute Percentage } \\
\text { Error (MAPE) }\end{array}$ & $\begin{array}{l}\text { Mean Absolute Deviation } \\
\text { (MAD) }\end{array}$ & $\begin{array}{c}\text { Mean Squared Deviation } \\
\text { (MSD) }\end{array}$ \\
\hline $\begin{array}{l}\text { Measures the accuracy of fitted } \\
\text { time series values as a } \\
\text { percentage. }\end{array}$ & $\begin{array}{l}\text { Measures the accuracy of } \\
\text { fitted time series values } \\
\text { in the same units as the } \\
\text { data. }\end{array}$ & $\begin{array}{l}\text { More sensitive measure of } \\
\text { an unusually large } \\
\text { forecast error than MAD. }\end{array}$ \\
\hline $\begin{array}{l}M A P E=\frac{\sum\left|\left(y_{t}-y_{t}^{1}\right) / y_{t}\right|}{n} x 100 \\
y_{t} \neq 0\end{array}$ & $M A D=\frac{\sum_{t=1}^{n}\left|y_{t}-y_{t}^{1}\right|}{n}$ & $M S D=\frac{\sum_{t=1}^{n}\left|y_{t}-y_{t}^{1}\right|^{2}}{n}$ \\
\hline
\end{tabular}

${ }^{*} y_{t}$ : actual value $, y_{t}{ }^{1}:$ fitted value, $n:$ number of observations 
The data can be detrended by either dividing the data by the trend component (multiplicative model) or subtracting the trend component from the data (additive model). The accuracy of the time series analysis can be expressed by mean absolute percentage error (MAPE), mean absolute deviation (MAD), and mean squared deviation (MSD) as shown in Table 5 (Minitab15 StatGuide). Smaller values generally indicate a better fitting model (Armstrong et al., 2004).

\subsubsection{Landfill Gas Emission Model (LandGEM)}

The Landfill Gas Emission Model (LandGEM) is widely used in the U.S to estimate the quantity of LFG produced. LandGEM is based on a first-order decomposition rate equation for quantifying emissions rates for total landfill gas, methane, carbon dioxide, nonmethane organic compounds (NMOCs), and individual air pollutants from decomposition of landfilled waste in MSW landfills (Alexander et al., 2005). The software provides a relatively simple approach to estimating landfill gas emissions. Model defaults are based on empirical data from U.S. landfills. Field test data can also be used in place of model defaults when available. In the absence of specific values of data default values are provided in LandGEM.

\subsection{Risk Analysis}

The purpose of the risk analysis is to analyze the migration pathways of pollutants from the site and to estimate health risks due to groundwater contamination. After reviewing risk assessment models, Framework for Risk Analysis Multimedia Environmental Systems (FRAMES) was selected to conduct the risk assessments for the case study landfills. Some metals and volatile organic compounds were chosen as the groundwater contaminants of concern and risk analysis program was run to estimate the 
health risks due to contaminants in the groundwater resulting from case study landfill. Human health risks were evaluated in terms of carcinogenic and noncarcinogenic effects due to exposure to contaminants present in the groundwater. FRAMES aided the study in constructing a conceptual site model (CSM), a site that is reconstructed on screen by defining the site parameters that represent the real or potential flow of contamination to the groundwater through the soil layers. The program (FRAMES) estimated the mass of the constituent remaining in the groundwater; constituent fluxes from the groundwater; intake by ingestion, inhalation and dermal contacts; and projected health risks (Whelan et al., 1997). FRAMES works with Multimedia Environmental Pollutant Assessment System (MEPAS). MEPAS is developed by Pacific Northwest National Laboratory (PNNL) to assess contaminated environmental problems. MEPAS simulates the release of contaminants from a source; transport through the air, groundwater, surface water, and/or overland pathways; and transfer through food chains and exposure pathways to the exposed individual or population. For human health impacts, risks are computed for carcinogens and hazard quotients for noncarcinogens.

\subsubsection{Sensitivity Analysis/ Factorial Design}

Sensitivity analysis was performed to analyze effects of different factors on risk assessment. For this purpose factorial design was chosen as sensitivity method. Factorial designs allow for the simultaneous study of the effects that several factors may have on a process. When performing an experiment, varying the levels of the factors simultaneously rather than one at a time is efficient in terms of time and cost, and also allows for the study of interactions between the factors. Interactions are the driving force in many processes. Without the use of factorial experiments, important interactions may 
remain undetected. In a full factorial experiment, responses are measured at all combinations of the factor levels, which may result in a prohibitive number of runs (Minitab 15 StatGuide). After running the FRAMES software to assess risk resulting from landfill, an experimental statistical factorial design was developed to how different values of variables such as Darcy velocity, thickness of soil, contaminant mass in aquifer and different soil types would impact the risk results. Factorial design facilitates the evaluation of the interactions of variables and thus assists the process of model building. These experimental designs provide estimates of the "effects" of the interactions, while assuring that such interactions are not experimental errors (Murphy et al., 1998). 3x3 factorial design was used for the experiment. These three factors are Darcy Velocity, thickness beneath the landfill and mass of contaminant detected in aquifer. Low, medium and high values were used as levels to set up a matrix. 


\section{CHAPTER 4}

\section{DAVIE LANDFILL FACILITY DESCRIPTION}

\subsection{Site Location and History}

The Davie landfill is located at 4401 S.W. $142^{\text {nd }}$ Avenue, Davie, Florida (Broward County). The site was operated as a landfill from 1964 to 1987. It is located on a 209 acre parcel of land as shown in Figure 6. After closing, a portion of the site (approximately 160 acres or around $78 \%$ of the land) was converted to a park, known as Vista View Park which opened to the public on July 2003. The chronicle history of Davie Landfill is explained in Table 6.

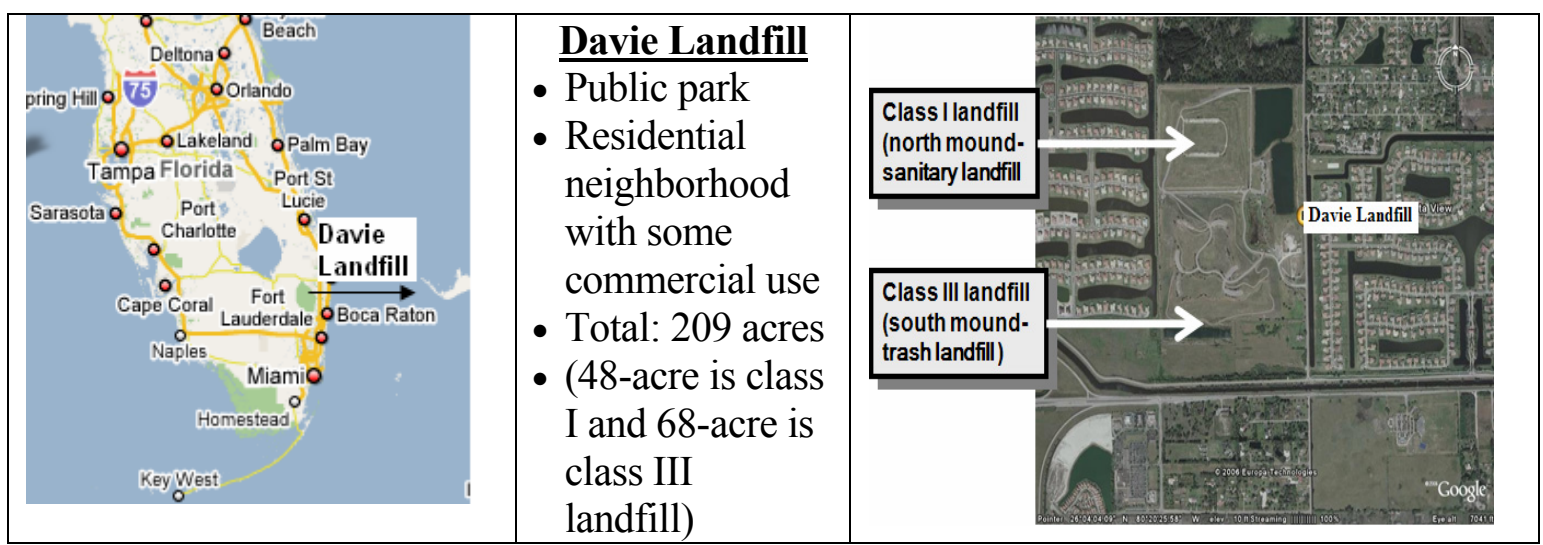

Figure 6. General location and characteristics of Davie Landfill.

Table 6. Chronicle history of Davie Landfill (Completion report, 2003).

\begin{tabular}{|l|l|}
\hline \multicolumn{1}{|c|}{ Event } & \multicolumn{1}{|c|}{ Date } \\
\hline Incinerator and trash landfill (south mound) operations commence & 1964 \\
\hline Unlined sludge lagoon created and operations begin & November 1971 \\
\hline $\begin{array}{l}\text { Shutdown of incinerator due to excessive particulate matter } \\
\text { emissions }\end{array}$ & June 1975 \\
\hline Landfills at subject site officially close - no longer accepting waste & December 1987 \\
\hline Solid Waste Post Closure Permit issued by FDEP & February 1995 \\
\hline $\begin{array}{l}\text { Broward County regional park, Vista View Park opened to the } \\
\text { public }\end{array}$ & July 12, 2003 \\
\hline
\end{tabular}




\subsection{Location Specific Factors}

\subsubsection{Weather}

The Davie landfill is located in a humid subtropical climate. May to October is the rainy season, and October to May is the dry season with average precipitation of 3 inch/month during the dry season and 8 inch/month during the rainy season. The average humidity is $70 \%$ and average temperature is between $70-82{ }^{0} \mathrm{~F}$. The site has also been affected by hurricane activity in the region. For example, in 2005, several hurricanes passed through Broward County (Hurricanes Wilma and Katrina) and resulted in significant damage and rainfall in the area.

\subsubsection{Ground Water}

The hydrogeological units that are located in the vicinity of the Davie Landfill Site are the Biscayne Aquifer which is a surficial aquifer and the Floridian Aquifer which is an artesian aquifer. The Biscayne is an unconfined aquifer, which is approximately 100 feet thick at the site and it is the only groundwater source for potable water in Broward County. The Biscayne Aquifer consists of two hydraulically connected units. The upper Biscayne Aquifer is approximately 50 feet thick and consists of a series of interbedded layers of sandy limestone, limestone and sandstone. The lower Biscayne Aquifer consists of approximately 50 feet of sand stone that contains large solution holes, which are at least partially filled with sand. The hydraulic conductivity of the upper unit is estimated at 300 gallons per day per foot $(\mathrm{gpd} / \mathrm{ft})$ and the hydraulic conductivity of the lower unit is estimated at $10,000 \mathrm{gpd} / \mathrm{ft}$. 


\subsubsection{Sensitive Receptors}

Sensitive receptors are areas that located around the site that could be affected by the landfill. The sensitive receptors around Davie Landfill are shown in Figure 7. These are;

- North New River Canal / South New River Canal,

- Camp Seminole of the South Florida Council of the Boys Scouts,

- Imagination farms (dairy farms), and

- A single-family residential development.

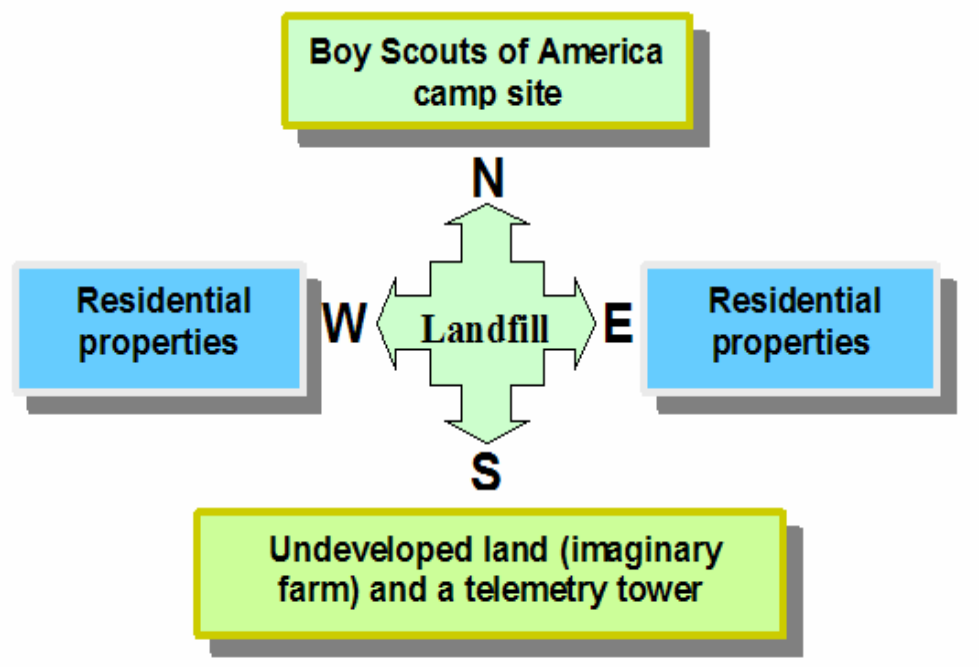

Figure 7. Sensitive receptors around the landfill area.

\subsection{Design Factors}

The landfill area is comprised of two mounds, the south mound (trash landfill) and north mound (sanitary landfill). The south mound is unlined and accepted incinerator ash, yard trash, construction and demolition debris, and other trash. The focus of this discussion involves only the north mound, which accepted unprocessed municipal solid waste. The cross section of the north mound is shown in Figure 8. 


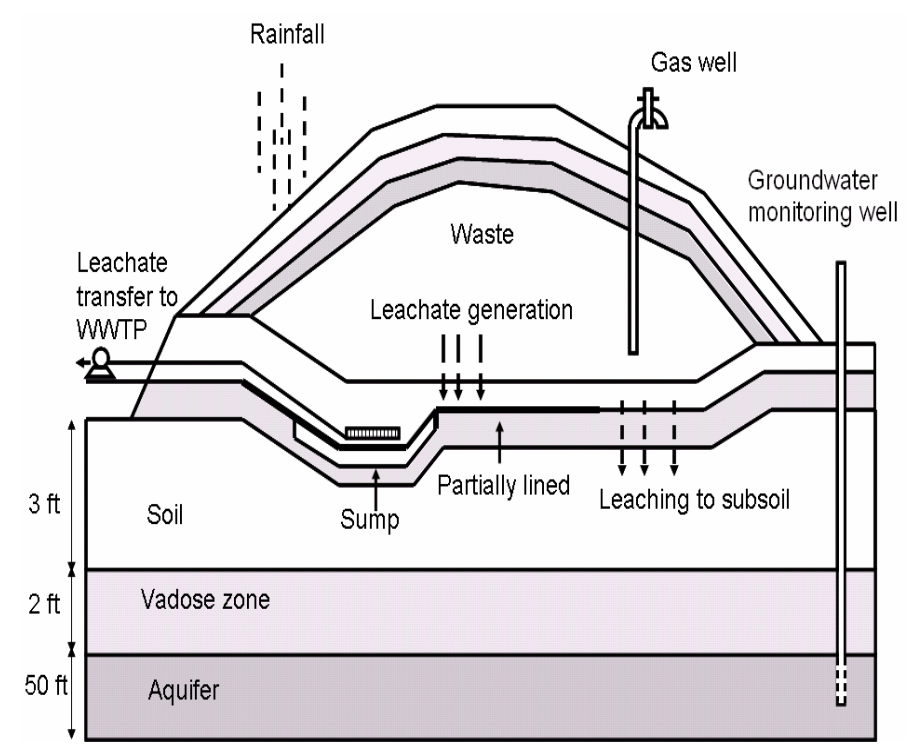

Figure 8. Cross section of north mound at Davie Landfill.

\subsubsection{Liner System}

The south mound is unlined and the north mound is partially lined. The north mound is made up of 14 cells. Cells 1-4 are located in the northwest portion of the north mound. Cells 5-13 are located immediately adjacent to the eastern face of cells 1-4 and progress to the eastern most boundary of the north mound. Cell 14 is the southernmost cell of the north mound and also overlays cells 1-13 up to the final elevation. Cells 1-4 were lined with a sprayed asphaltic liner and do not have a leachate collection system. Cells 5-13 are lined with paved asphalt with a leachate collection system. A secondary bentonite clay liner was installed at an elevation of 55-60 feet. Cell 14 was constructed with a 60 mil HDPE liner and leachate collection system.

\subsubsection{Cap}

In general, both the sanitary and trash landfill cover systems consist of two feet of limerock, which was compacted in six-inch layers and covered with six inches of vegetative soil. A total of 31,969 tons of lime rock was used as the landfill cover 
material, and approximately 21,000 tons were used for Cell 14. Two lifts of material (each 1-foot thick), was spread and compacted. The final cover was sloped at a $2 \%$ grade towards the southwest corner of the sanitary landfill. The slopes on the cover are relatively flat on the crown of the landfill cells, with slopes generally 1 to $3 \%$. The landfill has settled approximately five feet since 1987.

\subsubsection{Groundwater}

The potentiometric surface elevation of the underlying aquifer ranges from approximately 4 feet in the northwest section of the landfill to approximately 2.3 feet in the southeast section. As a result, the groundwater flows in a southeasterly direction. The regional groundwater gradient is reported to be about 0.4 feet per mile. The C-1 1 canal has a direct effect on the groundwater flow at the Davie Landfill Site. During periods of high flow, the canal becomes a recharge source for the aquifer and influences groundwater flow in a northerly direction. During periods of low flow, the canal acts as a discharge area for groundwater and enhances the groundwater flow in a southerly direction. Therefore, fluctuations in groundwater at the Davie Landfill site are directly related to precipitation and pumping events in the area.

\subsubsection{Leachate System}

The leachate collection system at the site drains into a main sump, where it is pumped through a leachate force main to the City of Sunrise wastewater treatment plant. Leachate samples are analyzed biannually.

\subsubsection{Surface Water}

The Davie Landfill site is located between two drainage canals. The North New River Canal (L-36) is approximately 3.5 miles to the north and the South New River 
Canal (C-11) is approximately 0.25 mile to the south. To the east of the landfill is a northsouth drainage ditch that drains into the $\mathrm{C}-11 \mathrm{Canal}$. This shallow ditch does not receive surface water runoff from the landfill. All surface water runoff is channeled to one of the borrow lakes. Lakes 1, 2 and a pond are physically connected. The northern area of the site drains to Lakes 1 and 2 and the southern area drains to Lake 3 shown in Figure 9. Around the site, there is a perimeter berm that is designed to hold stromwater for a 25year, 72-hour storm event.

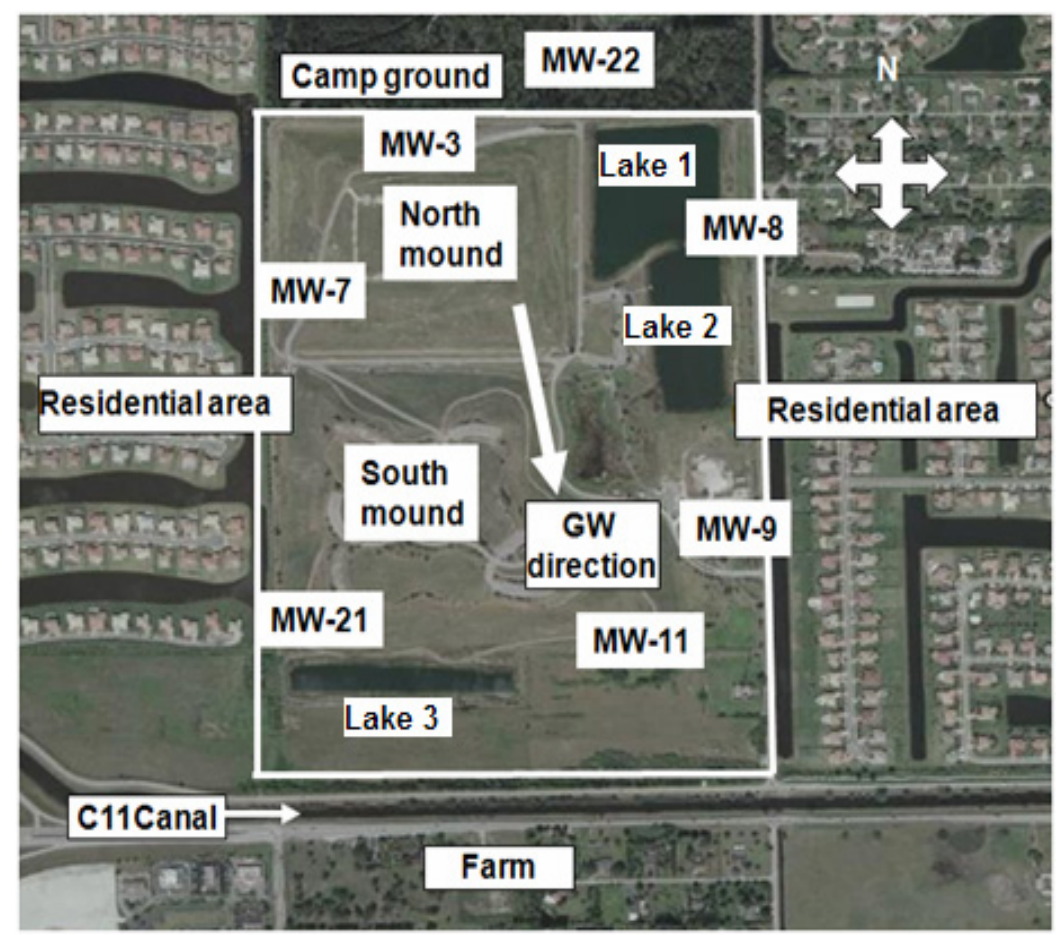

Figure 9. Landfill surface water.

\subsubsection{Landfill Gas Management System}

The landfill gas management system collects the gas produced at the landfill and eliminates it through an enclosed flare. The sanitary landfill gas collection and control system maintenance activities consist of monthly inspection of 33 gas extraction wells. 


\section{CHAPTER 5}

\section{MODULE EVALUATIONS}

\subsection{Leachate Module}

The purpose of the leachate module is to determine whether the leachate management practices can be optimized, reduced, or discontinued. For this reason, the leachate module was divided into two parts:

1. Evaluation of leachate quantity trends, and

2. Evaluation of leachate quality and projection of future trends for the contaminants of concern.

The results of the leachate module were used for the following purposes:

a. Evaluation of the levels of the contaminants of concern over time and comparison with MCLs,

b. Estimation of trends for the contaminant of concern, and

c. Projection of future concentrations and decision to continue or discontinue the monitoring for contaminants of concern.

\subsubsection{Leachate Quantity Trend}

Leachate quantity data were available from 1989 to 2008 . Figures 10 and 11 show that leachate quantity has been decreasing gradually over time. In Figure 11, leachate quantity data analyzed by time series included those from January 2001 to December 2005 (60 months). Figure 12 compares the rainfall and leachate quantity on a yearly basis. Both rainfall and leachate data have downward trend. When monthly leachate and rainfall data are compared, the correlation between the leachate quantity and rainfall can be noted based on the periodic peaks (due to dry and rainy seasons) observed as shown in 
Figure 13. The leachate quantity showed a decreasing trend over time. Leachate generation rates are significantly affected by meteorological conditions and the hydrologic properties of the cover and waste materials.

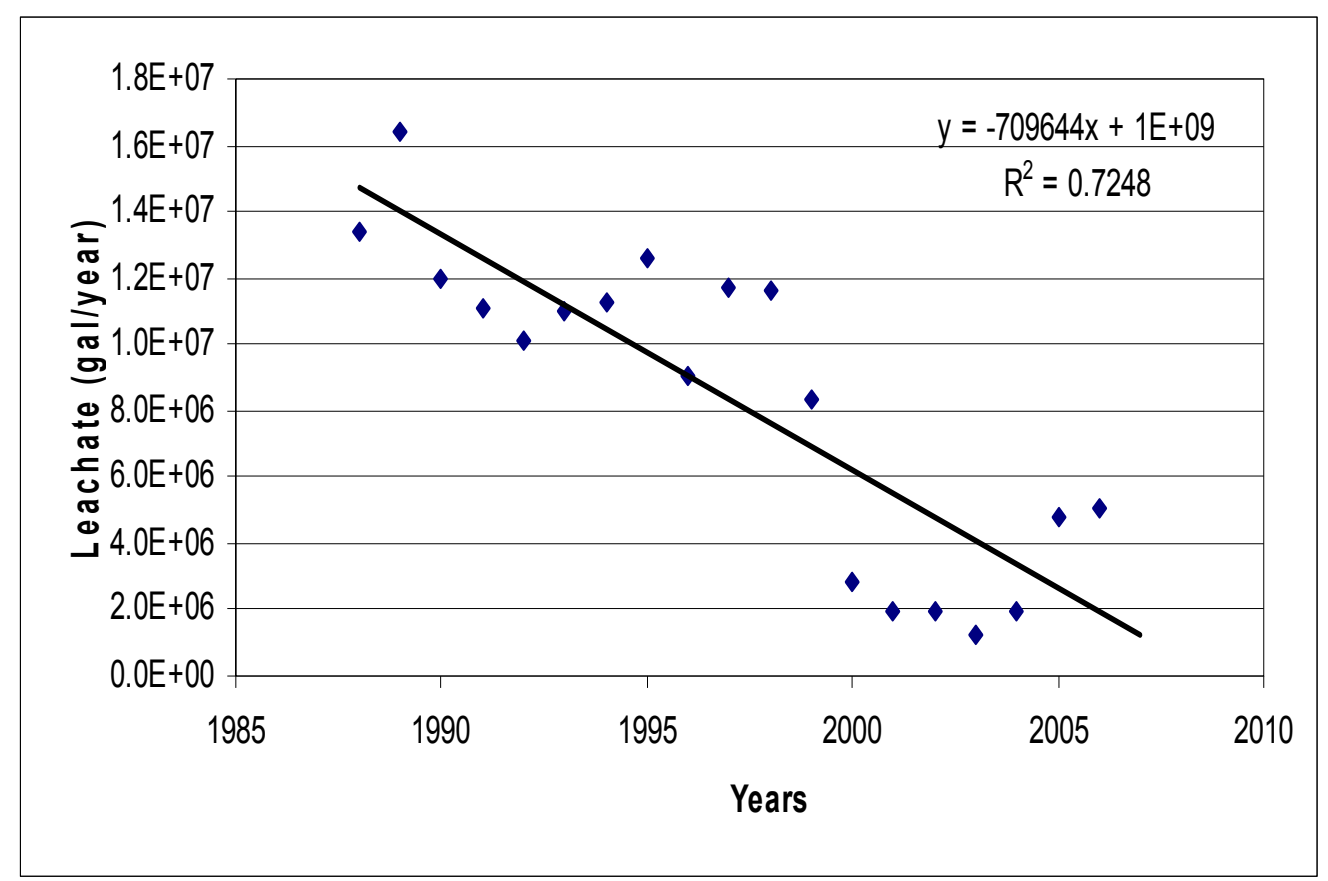

Figure 10. Annual leachate generation by years.

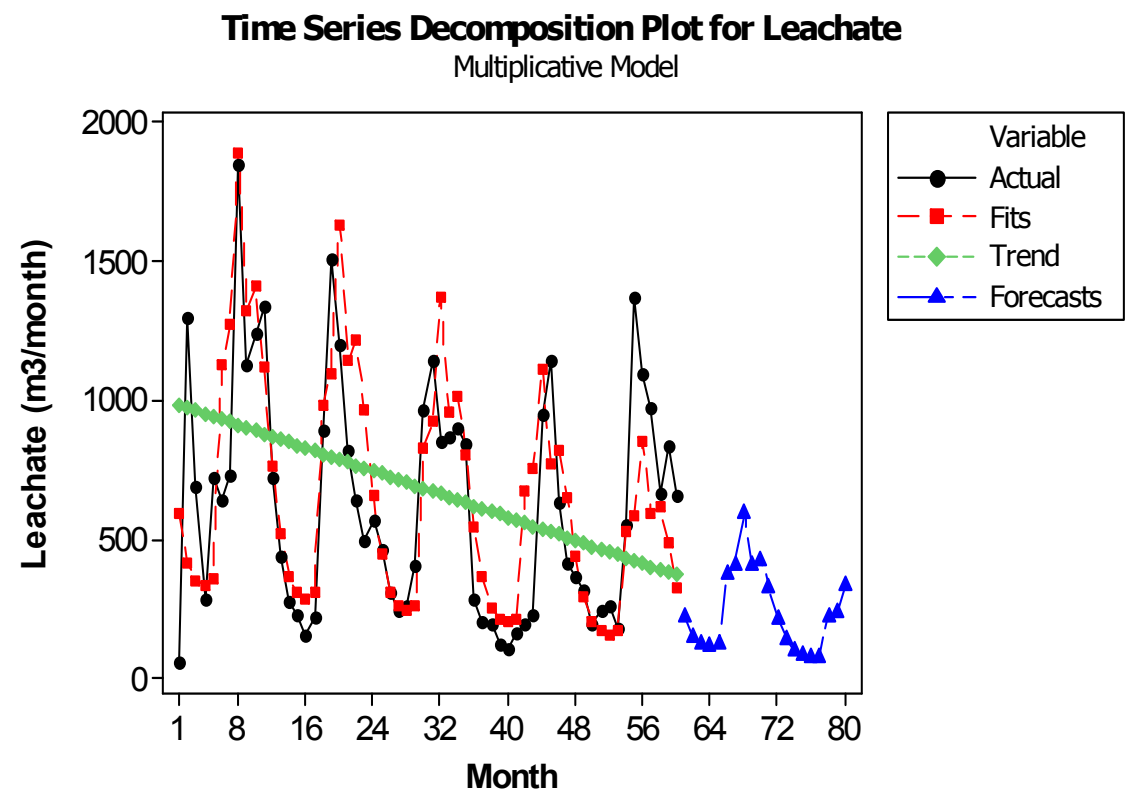

Figure 11. Time series projections of monthly leachate generation 


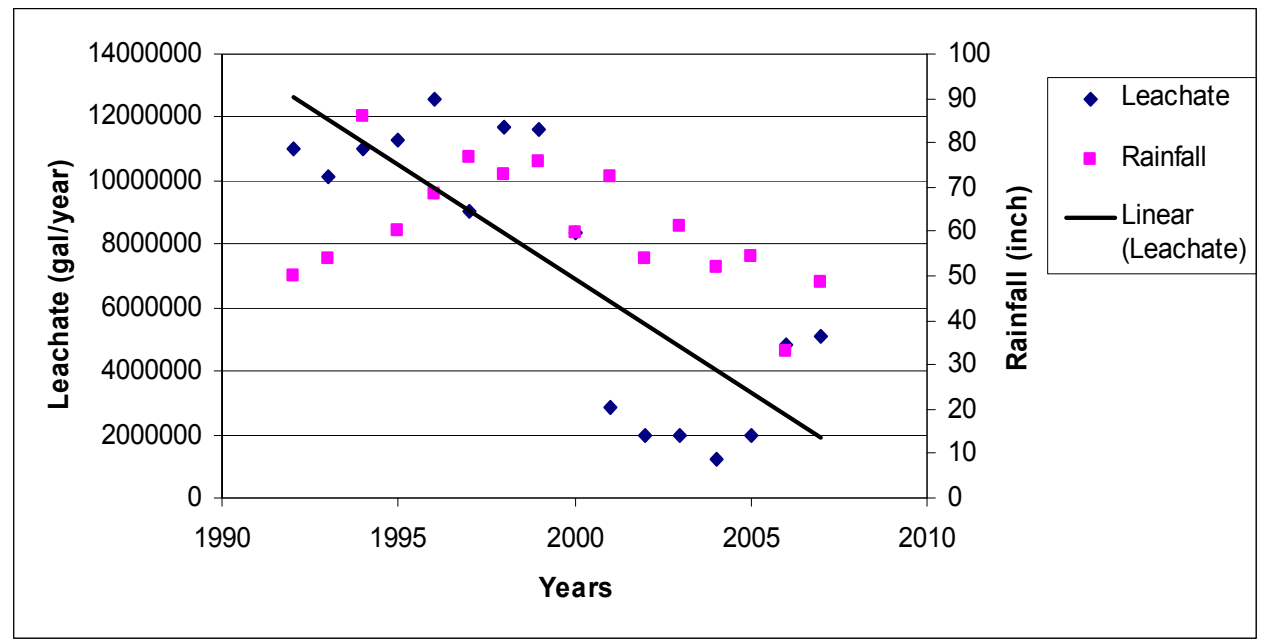

Figure 12. Yearly total leachate vs. rainfall.

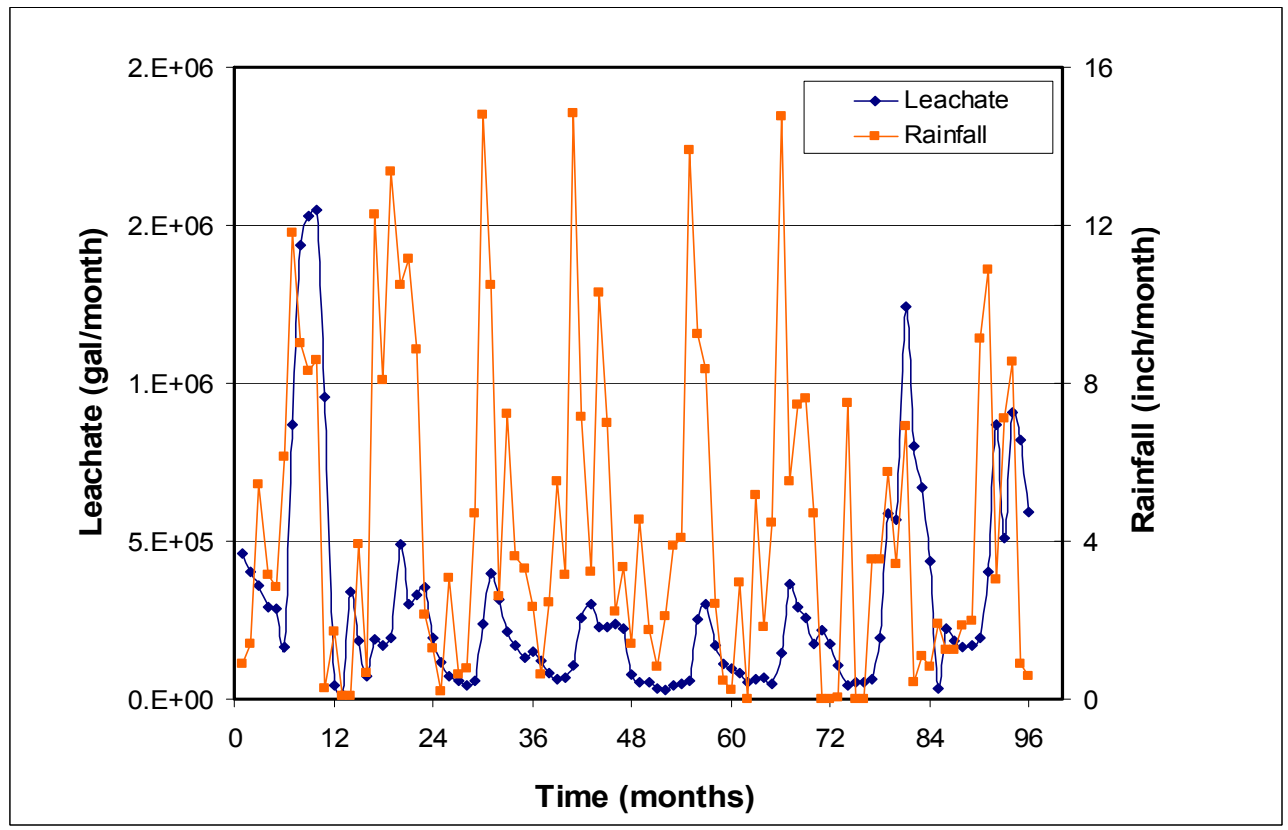

Figure 13. Monthly total leachate vs. monthly total rainfall.

Inspection of the recent data records showed an unusual trend (After 2003 leachate quantity suddenly increases) with no documented explanations in the reports available. Interviewing of the engineer responsible for the landfill site revealed that the meter that was used for monitoring the leachate quantity was broken and a new meter had been installed in 2006. Reassessment of the data by plotting the rainfall versus leachate quantity showed that the new meter had a different calibration scale from the previous 
meter. Figure 14 presents the annual average rainfall versus leachate quantity. The data collected with the new meter showed the discrepancies in the calibration of the old and new meters.

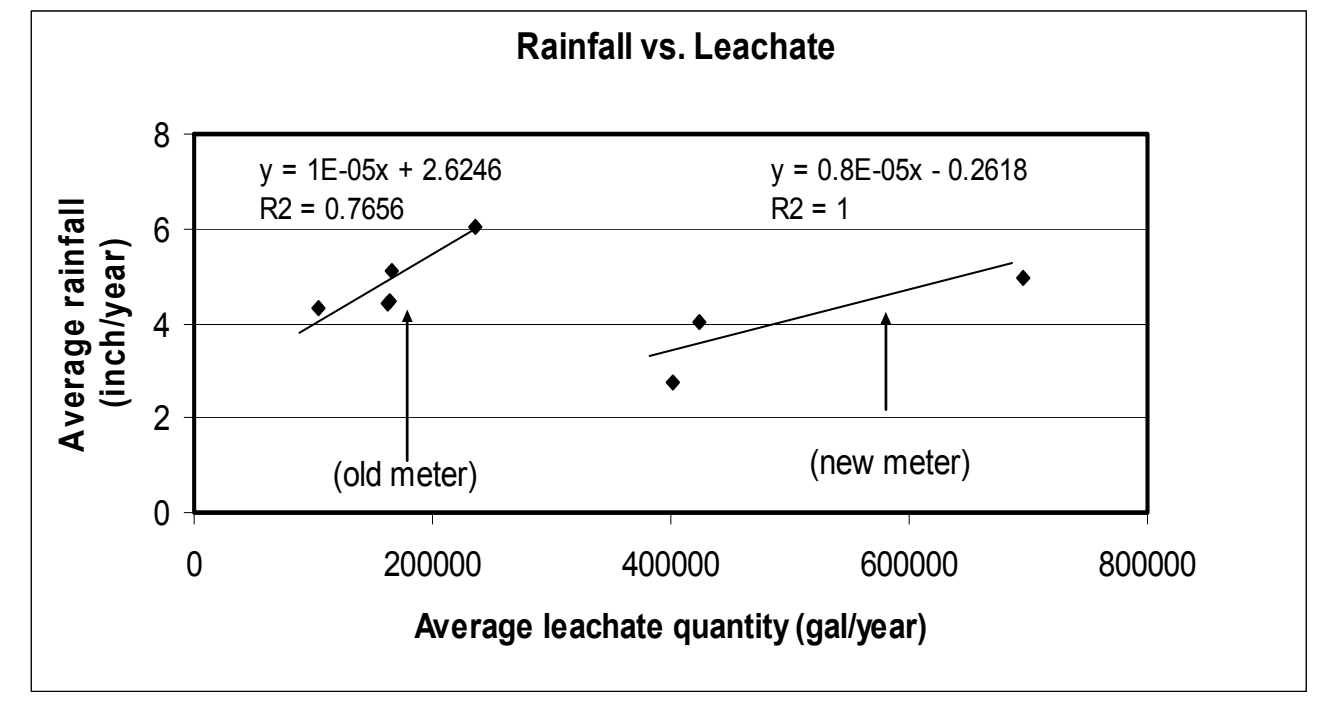

Figure 14. Average rainfall vs. average leachate at Davie Landfill.

\subsubsection{The Fate and Transport of Leachate}

The fate and transport of leachate from landfills is an environmental concern (Christenson et al., 2003). All liner systems eventually lose their integrity and some contaminants may be released to the environment (USEPA, 1988). During waste degradation, landfills go through four phases: (1) an initial aerobic phase, (2) an anaerobic acid phase, (3) an initial methanogenic phase, and (4) a stable methanogenic phase (Christensen and Kjeldsen, 1995). Existing data show that the chemical composition of leachate is highly dependent on the degradation stage of the waste. In the acid phase, concentrations are higher because of raised formation of dissolved organic matter and release of ammonia. In the methanogenic phase, the content of dissolved organic matter significantly decreases and the composition of the organic matter changes. 
The leachate contains four groups of pollutants: dissolved organic matter, inorganic macro components, heavy metals, and xenobiotic organic compounds (Kjeldsen et al., 2002). Anaerobic degradation of organic wastes produces about 40 to 45 percent methane, 55 to 60 percent carbon dioxide, and traces of other volatile and semivolatile organic compounds (Committee to Assess the Performance of Engineered Barriers, National Research Council, 2007). Depending on the types and concentrations of compounds present in leachate, the extent of stability of a landfill can be projected.

Pohland and Englebrecht (1976) reported initial increasing trend followed by a decreasing trend in concentrations of landfill leachate pollutants. Statom et al., (2004) presented decreasing trends for temperature, conductivity, TDS, COD, TOC, ammonia, TKN, nitrate, chloride, sodium, fluoride, alkalinity, boron, chromium, vanadium, cobalt, and nickel; and increasing level for calcium and TIC, iron and manganese concentrations; and stable trends for $\mathrm{pH}, \mathrm{BOD}$, phosphorus, sulfate, and magnesium. Sanin et al., (2000) reported on the presence and biodegration of toluene, acetone, and 1,2-dichoroethane in decomposing MSW. The literature for degradation of organic chemicals in landfills are still limited, unless specific degradation rates are retrieved for a specific case, default values on degradation cannot be suggested (Christensen et al., 2001).

\subsubsection{Leachate Quality}

The leachate quality was monitored twice a year (April and September). Leachate samples were collected biannually until 2006. After 2006, the management decided to collect the leachate samples once a year. A total of 46 parameters were monitored. Among these parameters, 28 parameters were non-detected parameters (i.e., always 
below the detection limit), 8 parameters were always above the Maximum Contaminant Level (MCL) and 10 parameters were below the MCL as presented in Table 7.

Table 7. Parameters of interest in leachate at Davie Landfill.

\begin{tabular}{|l|l|}
\hline Below MCL & Above MCL \\
\hline 1,4-Dichlorobenzene & Chloride \\
\hline Chlorobenzene & Bicarbonate \\
\hline cis-1,2-Dichloroethylene & Sodium \\
\hline Dichlorodifluoromethane & Ammonium as N \\
\hline Ethylbenzene & Iron \\
\hline Methyl-tert-butyl ether (MTBE) & Benzene \\
\hline Tetrachloroethene & Vinyl Chloride \\
\hline Toluene & Total Dissolved Solids \\
\hline Xylenes & \\
\hline Total BTEX & \\
\hline
\end{tabular}

Initially, the available data were plotted as a function of time to fit a trend line with regression analysis. However, a clear trend (i.e., decreasing or increasing) could not be identified due to significant seasonal variations in the data. The samples collected at the end of the dry season (April) had higher concentrations; and the samples collected at the end of the rainy season (September) had lower levels due to dilution by rain water. Similar observations on leachate quality due to seasonal effects have been reported in the literature. Chu et al. (1994) observed a strong correlation between rainfall levels and leachate strength with high rainfall conditions correlating with lower strength and low rainfall correlating with higher strength of leachate quality. Akesson and Nilsson (1997) reported lower leachate concentrations during the wet season in a Swedish landfill test cell. The data were analyzed by time series decomposition method using MINITAB 15 software. Decomposition method separates the times series into a trend component that is a smooth function of time that may have a simple parametric form, a seasonal component which represents a pattern that is repeated every year, and an error component which is 
independent and identically distributed with mean zero. Time series decomposition approach is a quick and easy method of generation a range of parameters forecast (Worrall et al., 1998). It can be used by either selecting an additive or multiplicative model. The additive model assumes that amplitude of both the seasonal and irregular variations in data do not change as the level of the trend rises or falls. The multiplicative model assumes that the amplitude of both the seasonal and irregular variations increase as the level of the trend rises. The data from the case study landfill showed more adequate fit with the multiplicative model with a linear parametric component $\left(T_{t}\right)$. Therefore, time series decomposition with multiplicative model was used for the trend analyses.

\subsubsection{Leachate Quality Trend}

Leachate monitoring data were evaluated to forecast the stability of a Davie landfill. The analyses of the monitoring data showed a strong correlation with the sampling time during the year. The samples collected at the end of the dry season (April) had high concentrations; and the samples collected at the end of the rainy season (September) had lower levels due to dilution by rain water. Seasonality of the data was identified by the patterns which corresponded with the annual sampling cycles. Time series decomposition with multiplicative model was used for the trend analysis.

Figure 15 presents the sodium levels in leachate from April 2001 to April 2006. Sodium is generally derived from dissolution of salt in the landfills (Statom et al., 2004). The time series model was adequate. The only significant discrepancy between the data and the model was for 2002 September data. When the data was examined, it was seen that the April 2002 and September 2002 data were exactly the same. It is possible that 
this data was not actually collected in the field. Based on the time series forecast, sodium concentration would be below the MCL by the year 2011 .

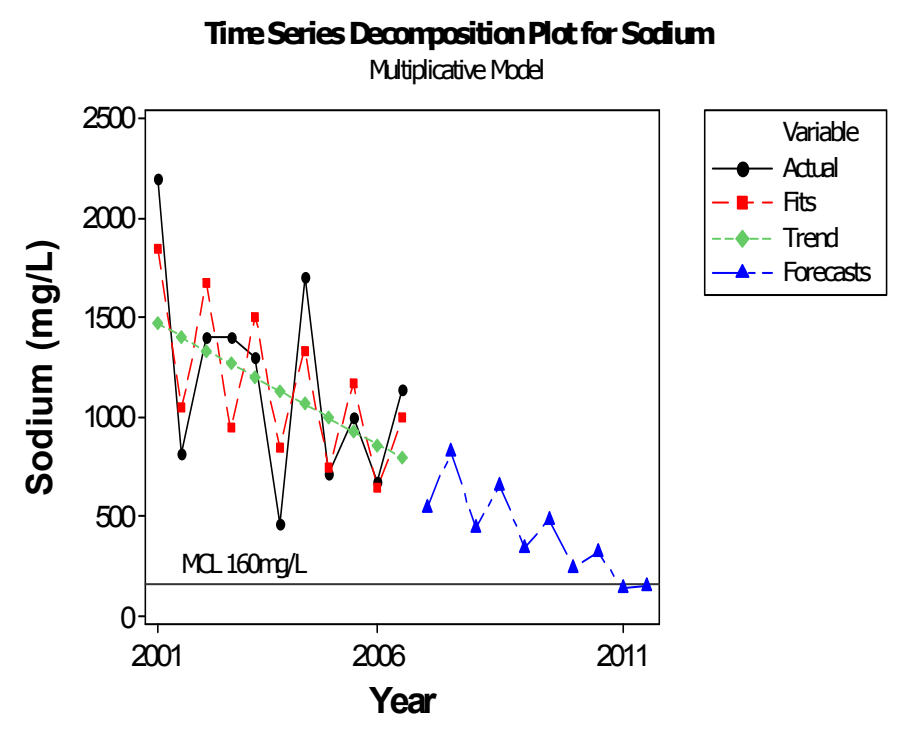

Figure 15. Time series projection for sodium generation.

Figure 16 presents the chloride levels in leachate from April 2001 to April 2006. The data after 2006 were not used due to changes in the sampling period. During April 2001 to April 2006, sampling was done twice a year (April and September). After 2006, the sampling frequency was changed to once a year. The trend predicted by time series decomposition method was adequate. Based on the projections, chloride concentration would be below the MCL by the year 2023. Statom et al. (2004) reported chloride displayed a short increasing trend early in the decomposition stage and then an overall decreasing trend. The major sources of chlorine in MSW are paper and plastics (U.S. Congress, Office of Technology Assessment, 1989). When chlorine combines with other available elements, it turns to chloride.

Figure 17 presents the concentration of total dissolved solids (TDS) in leachate from April 2001 to April 2006. The major contributors to TDS are sodium and chloride. 
Since both sodium and chloride have decreasing trends, TDS is also showed a decreasing trend. Statom et al. (2004) also reported a declining trend for TDS in leachate. The model was adequate for the TDS monitoring data.

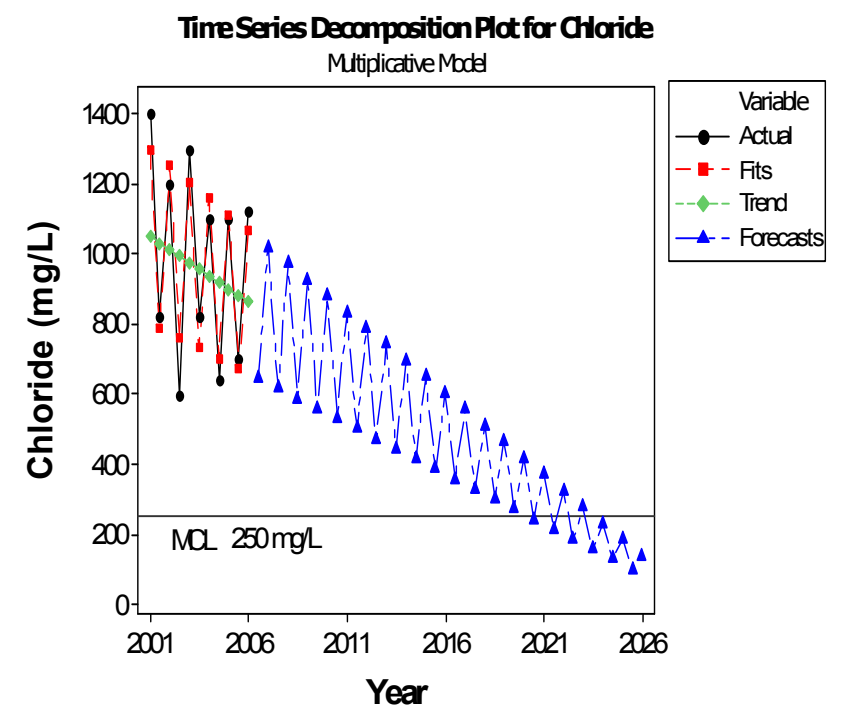

Figure 16. Time series projection for chloride generation.

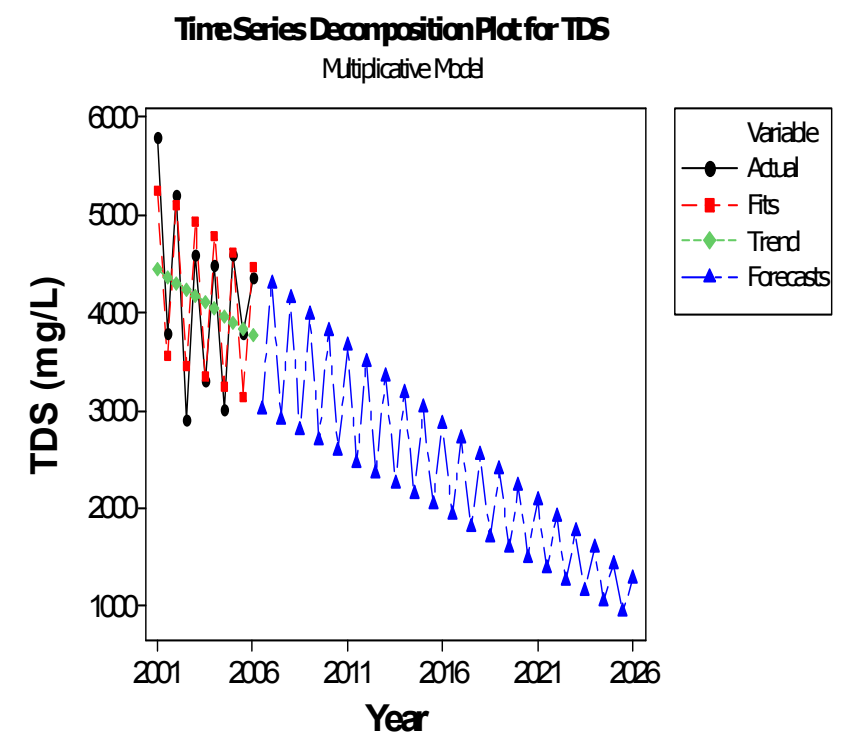

Figure 17. Time series projection for Total Dissolved Solids generation.

Figure 18 presents the iron concentrations (total concentration of iron regardless of species e.g. $\mathrm{Fe}^{+2}$ or $\mathrm{Fe}^{+3}$ ) in leachate. The data used included those from April 2001 to 
April 2006. The model projections show that iron levels are increasing over time. Projections showed a good fit for the data collected in 2007 and 2008. The oxidationreduction potential (Eh) and $\mathrm{pH}$ affect the solubility of metals. Charlatchka and Cambier (2000) reported that the concentrations of zinc, manganese, and iron increased with increasing Eh in agricultural soils polluted with metals. Other factors affect the solubility of metals include the cation exchange capacity (CEC) of the waste, how CEC changes during MSW decomposition, and the presence of more oxidized functional groups on the solid humic matter in MSW and humic matter in leachate (Aulin et al., 1997; Martensson et al., 1999).

Carboxylic acids can act as chelators during the waste decomposition resulting in dissolution of iron (Calmano et al., 1993; Bozkurt et al., 1997; Kjeldsen et al., 2002). Dissolved iron concentrations increase in leachate during transfer electrons to the iron on the mineral coatings by microorganisms while degrading the organic matter. With the addition of an electron, the iron is reduced to ferrous form which dissolves in water (Christenson et al., 2003). Statom et al. (2004) reported that after closure of a landfill iron concentrations first fluctuated and then significantly increased (Statom et al., 2004). Iron can corrode under anaerobic conditions, especially during the acid phase when low $\mathrm{pH}$ environment causes substantial corrosion (Scully, 1990). Although, many landfills show slightly acidic $\mathrm{pH}$ environment due to the presence of adequate buffer in the waste (Christensen et al., 1992); anaerobic conditions provide a favorable conditions for corrosion of iron over time by the following reaction (Reardon, 1995; Kjeldsen et al., 2002):

$$
\mathrm{Fe}(\mathrm{s})+2 \mathrm{H}_{2} \mathrm{O}(1) \rightarrow \mathrm{Fe}^{2+}+2 \mathrm{OH}^{-}+\mathrm{H}_{2}(\mathrm{~g}) \rightarrow \mathrm{Fe}(\mathrm{OH})_{2}(\mathrm{~s})+\mathrm{H}_{2}(\mathrm{~g})
$$




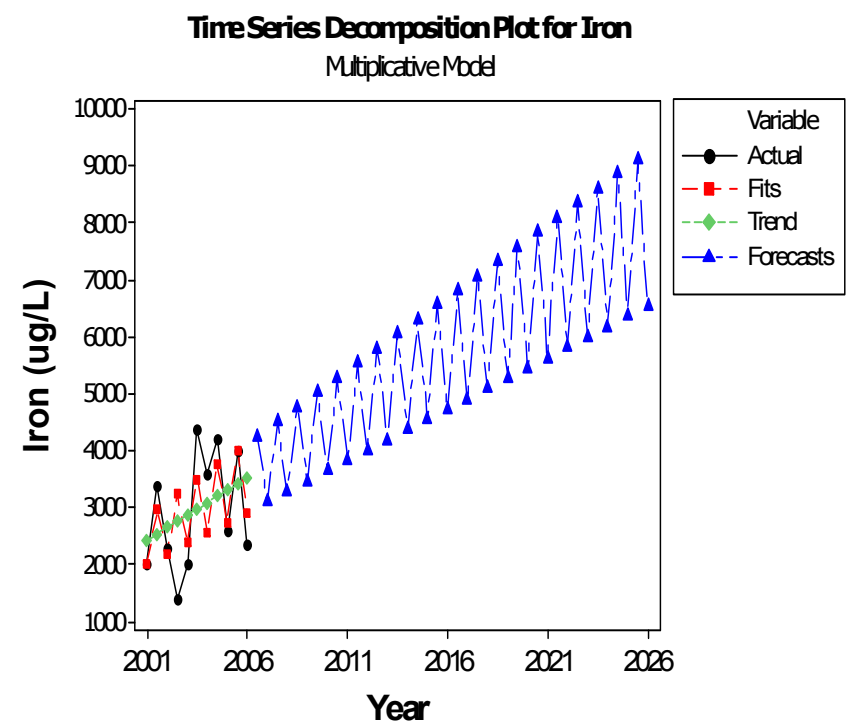

Figure 18. Time series projection for iron generation.

Figure 19 presents the $\mathrm{pH}$ levels of leachate from April 2001 to April 2006. The $\mathrm{pH}$ was relatively steady during the recent years and projected to be between 7.3 and 7.8 in the future.

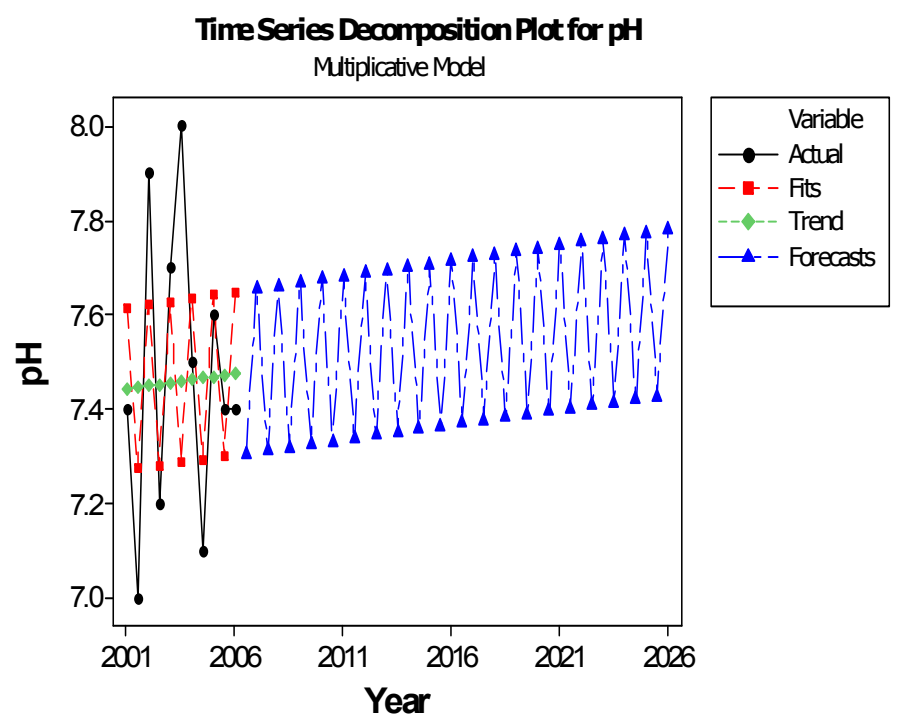

Figure 19. Time series projection for $\mathrm{pH}$.

Figure 20 presents the bicarbonate levels in leachate from September 2001 to September 2005. The data collected in April 2006 had a very high value and it was 
considered as an outlier. The figure shows that bicarbonate has an increasing trend. As the organic content of the waste is a decomposed, significant amount of bicarbonate forms as a byproduct of bacterial respiration (Klinck et al., 1999). The other source for bicarbonate is the cap system of the landfill which consists of a two-foot thick lime rock, a commonly found natural material in Florida. The lime rock consists of primarily calcium carbonate and it is the consolidated or partially consolidated form of limestone. The rain water slowly dissolves the limestone cap creating voids or cavities within the limestone cover by the following reactions (www.swfwmd.state.fl.us/sinkholes.pdf)

$$
\begin{aligned}
& \mathrm{CaCO}_{3}+2 \mathrm{H}_{2} \mathrm{O} \rightarrow \mathrm{Ca}(\mathrm{OH})_{2}+\mathrm{H}_{2} \mathrm{CO}_{3} \\
& \mathrm{H}_{2} \mathrm{CO}_{3} \rightarrow \mathrm{H}^{+}+\mathrm{HCO}_{3}^{-}
\end{aligned}
$$

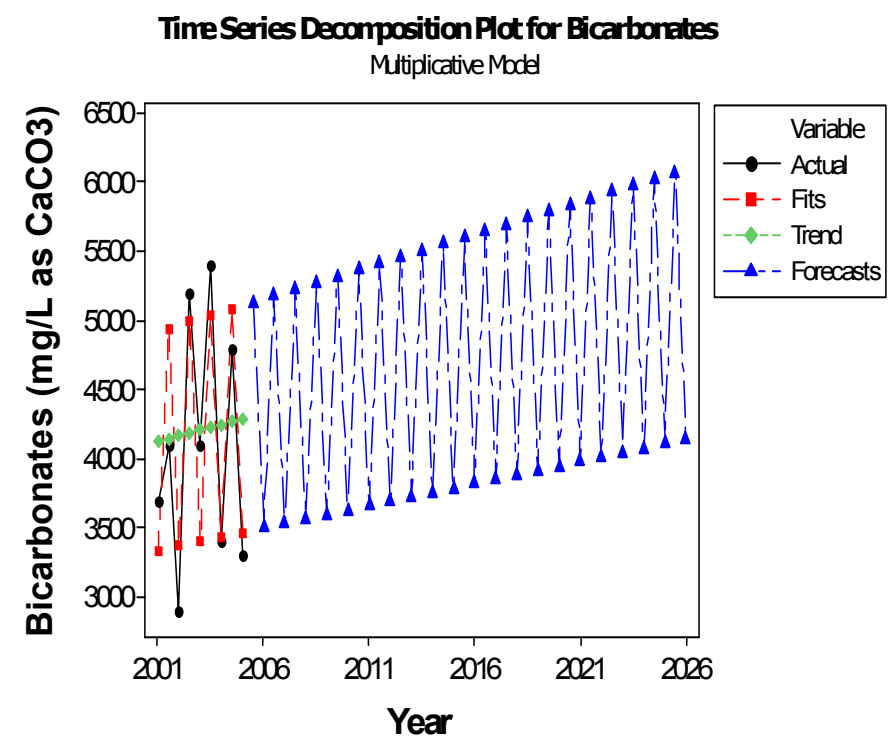

Figure 20. Time series projection for bicarbonate generation.

Figure 21 presents the ammonia levels in leachate from April 2001 to April 2006. Although the time series projections indicate a decreasing trend, field data showed a steady trend for ammonia levels. Ammonia data did not show the typical seasonal trend in 2003 and 2004. Although the time series model underestimated the ammonia levels, 
the values predicted for 2007 and 2008 were very close to the field monitoring data. The projection shows that ammonia concentration in leachate will be close to zero in 2014 . According to available literature, ammonia concentrations decline with the age of the landfills. Pohland and Harper (1986) observed higher ammonia levels during the acidogenic phase because of protein breakdown, then lower levels and decreasing trend during of biological assimilation in the methanogenic phase (Reinhart et al., 1998). Kjeldsen et al. (2002) reported no decreasing trend in concentration of ammonia over time due to the decomposition of proteins. The only mechanism by which the ammonia concentration can decrease during waste decomposition is leaching since there is no mechanism for degradation of ammonia under methanogenic conditions (Robinson, 1995; Burton and Watson-Craik, 1998). Kjeldsen et al. (2002) and Statom et al. (2004) observed that ammonia showed a short increasing trend early during the waste decomposition and then an overall decreasing trend.

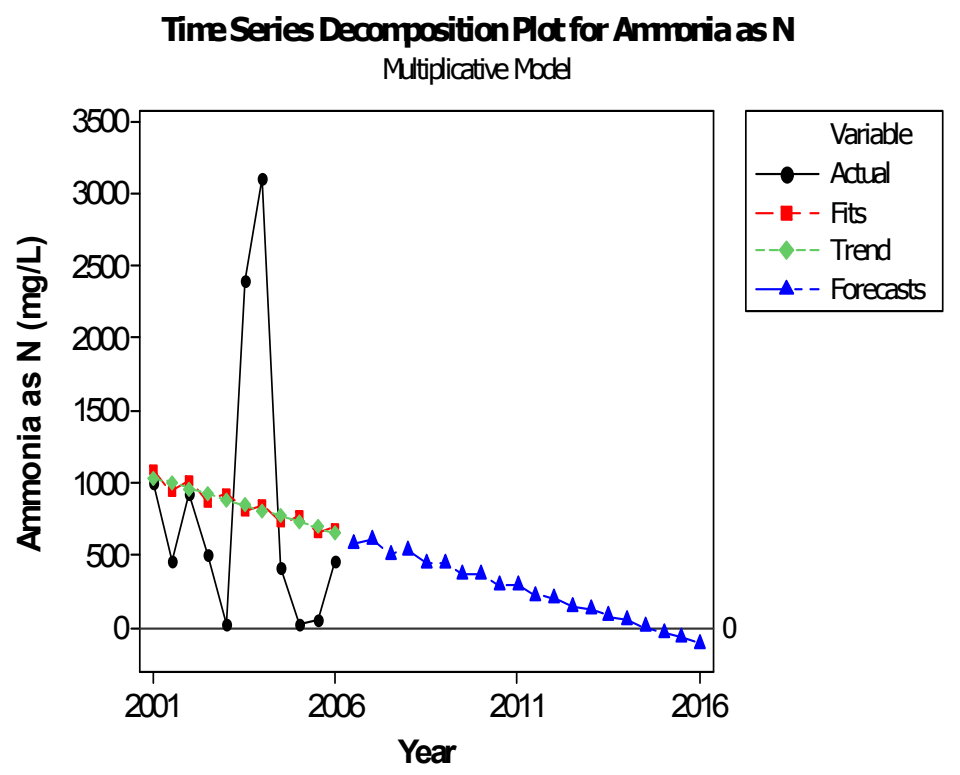

Figure 21. Time series projection for Ammonia as $\mathrm{N}$ generation. 
Figure 22 presents the vinyl chloride levels in leachate from September 2001 to April 2006. Vinyl chloride did not show a typical seasonal variation. The time series model underestimated the vinyl chloride concentrations. The projected values indicate a declining trend for vinyl chloride and the predicted values for 2007 and 2008 were very close the field data.

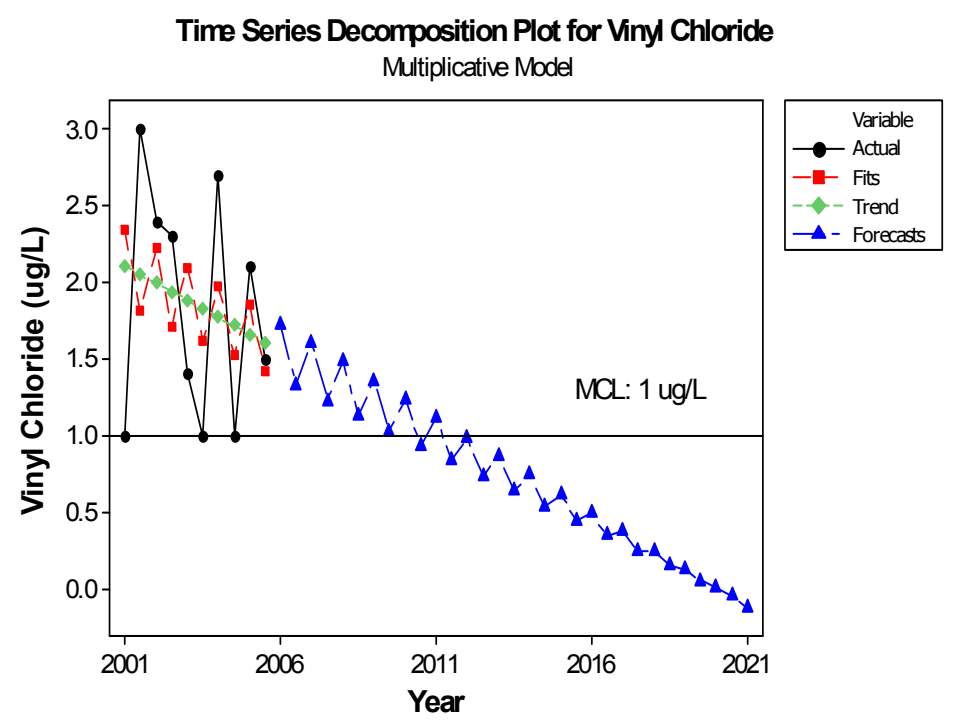

Figure 22. Time series projection for vinyl chloride generation.

In the literature there were no definitive data on the trends of VOCs compounds as a function of time or state of decomposition in modern Subtitle D landfills. Figure 23a presents the 1,4-dichlorobenzene levels in leachate from September 2001 to April 2006. Both the field data and the time series projections show a declining trend for 1,4dichlorobenzene. Figure $23 \mathrm{~b}$ presents the chlorobenzene levels in leachate from September 2001 to April 2006. Although projections indicate an increasing trend, field data showed a steady trend for chlorobenzene. Chlorobenzene is produced during anaerobic biodegradation of 1,4-dichlorobenzene (Lawrence, 2006; Middeldorp,1996). 
Therefore, the declining trend of 1,4-dichlorobenzene may correspond with the increasing trend of chlorobenzene according to the following reaction:

$$
\begin{aligned}
& \mathrm{C}_{6} \mathrm{H}_{4} \mathrm{Cl}_{2}+2 \mathrm{H}^{+}+2 \mathrm{e}^{-} \rightarrow \mathrm{C}_{6} \mathrm{H}_{5} \mathrm{Cl}+\mathrm{H}^{+}+\mathrm{Cl}^{-} \\
& (\underline{1,4-d i c h l o r o b e n z e n e}) \rightarrow \text { (chlorobenzene })
\end{aligned}
$$

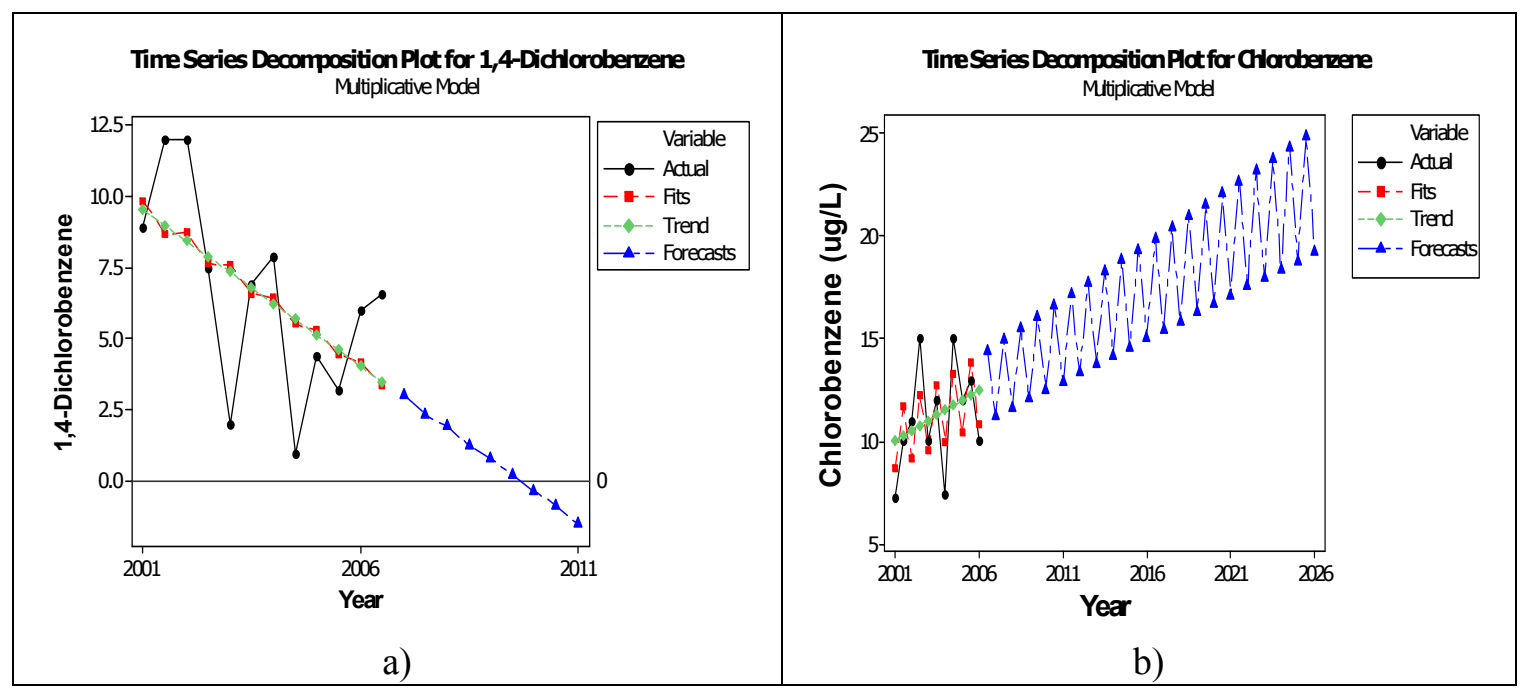

Figure 23. Time series projection for a) 1,4 dichlorobenzene generation b) chlorobenzene generation.

Degradation might play a significant role in the long-term fate of VOCs. The highly chlorinated alkenes commonly serve as the electron acceptors during anaerobic biodegradation (Vogel et al., 1987). The primary anaerobic process for degradation of chlorinated VOCs, except VC, is reductive dechlorination. Tetrachloroethene and TCE are the most susceptible to reductive dechlorination because they are the most oxidized forms of the chlorinated ethenes. However, the more reduced degradation by-products such as trichloroethenes and vinyl chloride are less prone to reductive dechlorination. The main by-products of anaerobic biodegradation of the polychlorinated ethenes are cis-1,2dichloroethane and vinyl chloride as shown in Figure 24a. A study by Ramanand et al., 
(1993) suggested that 1,2,4-trichlorobenzene could be biodegraded to chlorobenzene with 1,4-dichlorobenzene as the intermediate compound under anaerobic conditions. Middeldorp et al., (1997) showed that 1,2,4-trichlorobenzene was reductively dechlorinated to 1,4-dichlorobenzene, then to chlorobenzene in a methanogenic laboratory microcosm in which chlorobenzene contaminated sediments were enriched with lactate, glucose, and ethanol as presented in Figure 24b.

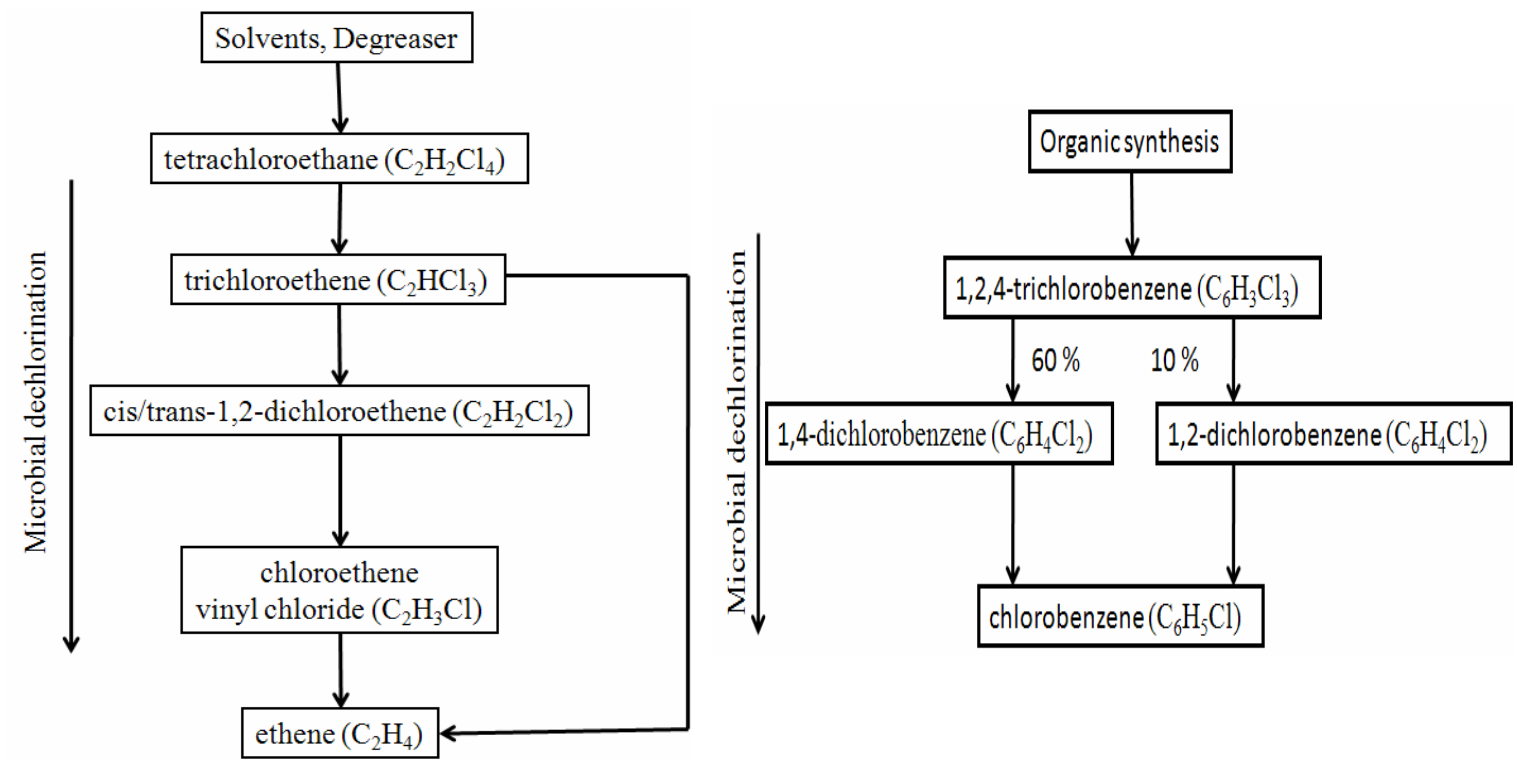

(a)

(b)

Figure 24. Anaerobic formation and biodegradation of chlorinated VOCs in MSW, (a) tetrachlorethane (b) 1,2,4-trichlorobenzene (adapted from Lawrance, 2006).

Figure 25 presents the benzene concentrations in leachate from April 2001 to April 2006. The general trend for benzene levels is declining. Based on the projections, benzene concentration would be below the MCL by the year 2028. The source of benzene in leachate may be decomposition of aromatic compounds or the petroleum products present in the waste. 


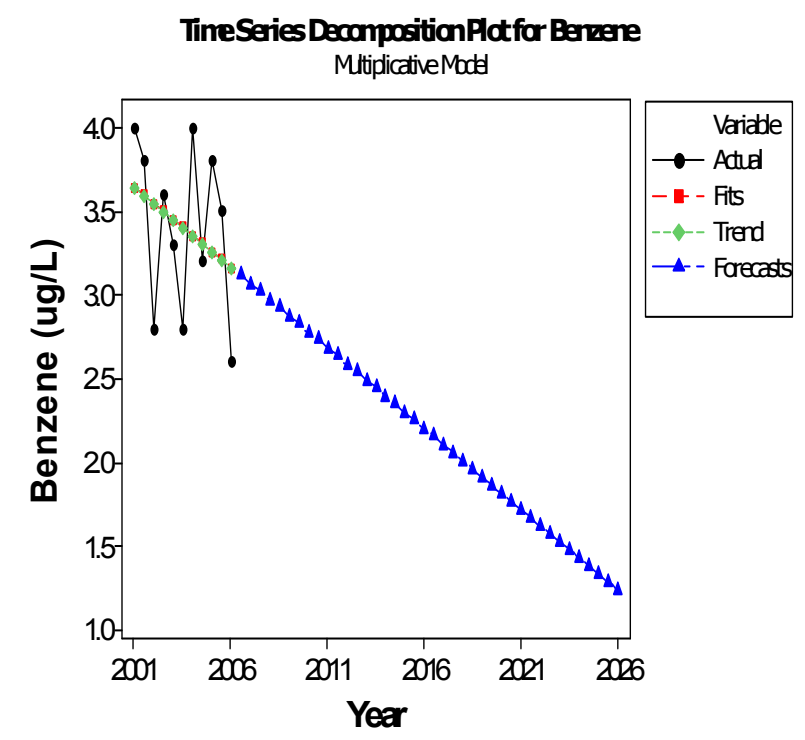

Figure 25. Time series projection for benzene generation.

Figures 26 a,b,c,d present levels of toluene, ethylbenzene, xylenes, and total BTEX in leachate, respectively. The projected trends for these VOCs showed a declining trend.

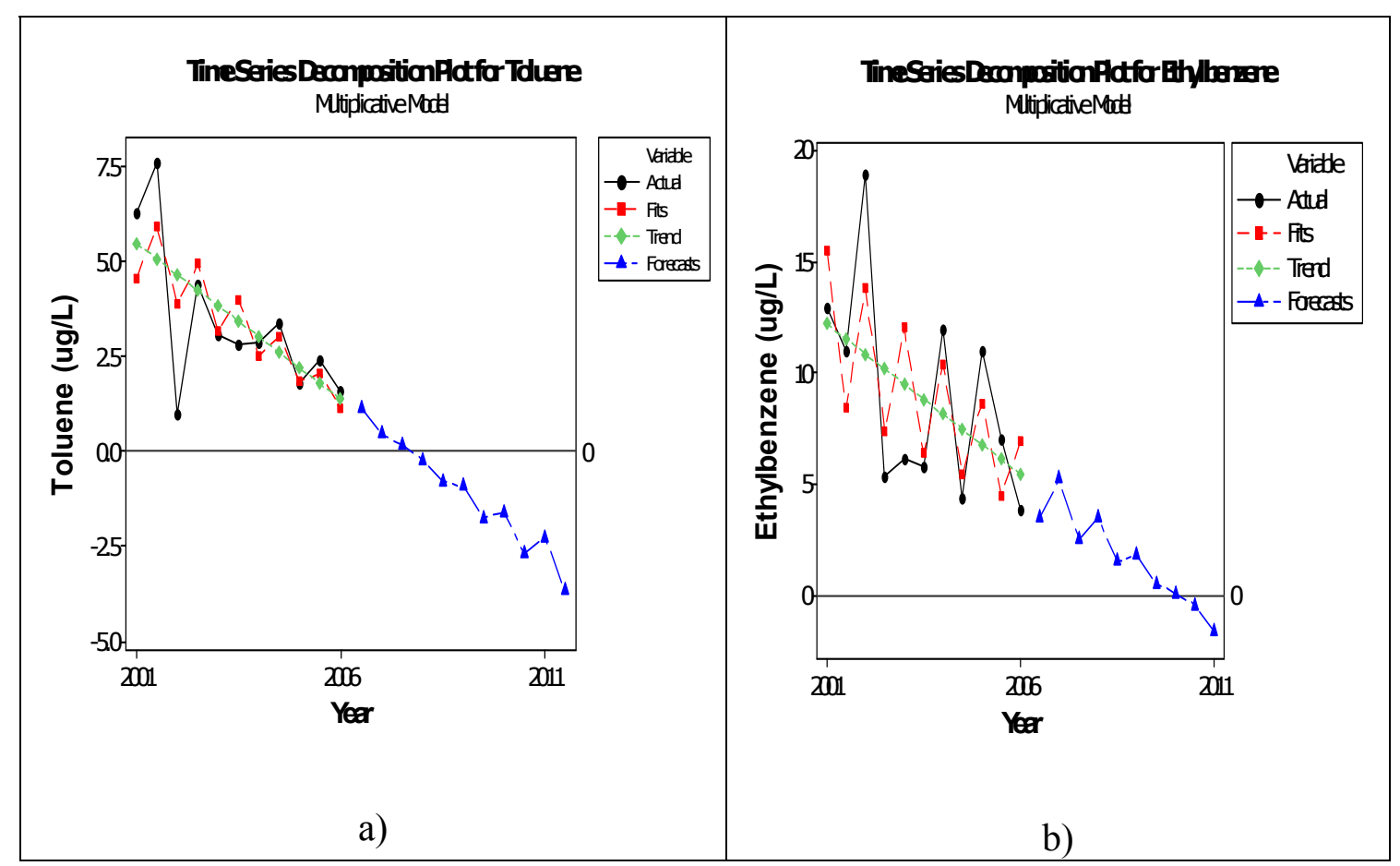




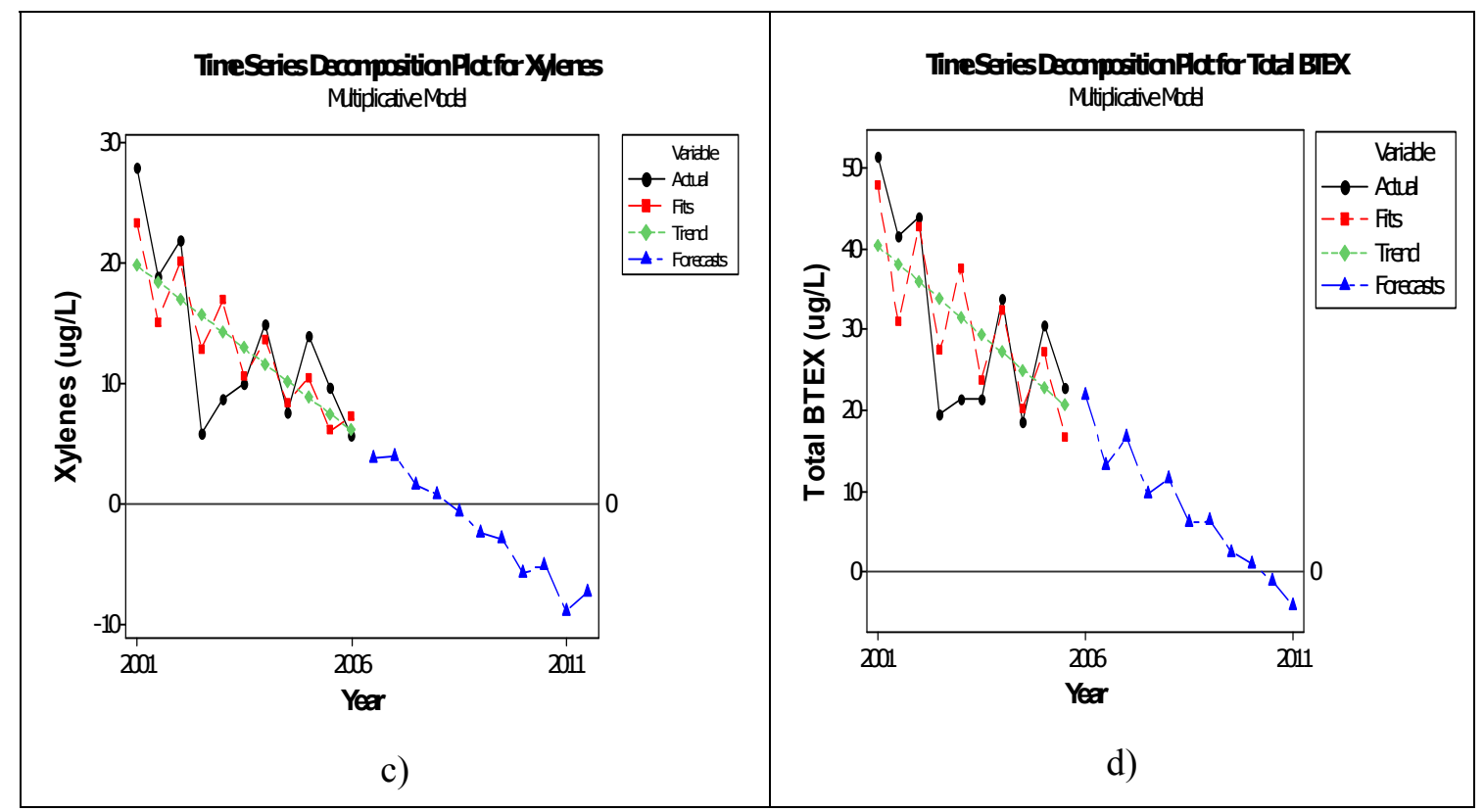

Figure 26. Time series projection for a) toluene b)ethylbenzene c)xylene d) Total BTEX generation.

In general, volatile organic compounds (VOCs) are relatively small compounds with high solubility in water, high vapor pressure, high Henry's constant, low organic carbon partition coefficient( Koc), high octanol water partition coefficient (Kow), and low bioconcentration factor (BCF) (LaGrega, 2001). Due to their relatively high vapor pressures, they do not show a persisting trend in leachate. Based on the projections, leachate quality would reach below MCL between 2010 (for vinyl chloride) and 2031 (for TDS) for all the parameters monitored. Although total BTEX is already below MCL, benzene levels are projected to be below MCL by the year 2030. Decreasing trends were observed and projected for leachate quantity, chloride, sodium , total dissolved solids, vinyl chloride,1,4-dichlorobenzene, chlorobenzene, xylenes, ethylbenzene, toluene, and total BTEX. Increasing trends were observed and projected for concentrations of iron, bicarbonate, and chlorobenzene. Table 8 summarizes the projected trends of leachate quality parameters monitored. 
Table 8. Leachate quantity and quality trends and general comments.

\begin{tabular}{|c|c|c|c|c|c|}
\hline Parameter & Trend & $\begin{array}{c}\text { Max } \\
\text { Value }\end{array}$ & $\begin{array}{c}\text { Min } \\
\text { Value }\end{array}$ & Mean & Comment \\
\hline $\begin{array}{l}\text { Leachate quantity } \\
\left(\mathrm{m}^{3} / \text { month }\right)\end{array}$ & Decreasing & 1847 & 54 & 630 & $\begin{array}{l}\text { Projections and observations } \\
\text { indicate decreasing trend }\end{array}$ \\
\hline Sodium (mg/L) & Decreasing & 2200 & 460 & $\begin{array}{c}1150 . \\
5\end{array}$ & MCL will be reached in 2011. \\
\hline Chloride $(\mathrm{mg} / \mathrm{L})$ & Decreasing & 1400 & 600 & 984.3 & MCL will be reached in 2023. \\
\hline Iron $(\mu \mathrm{g} / \mathrm{L})$ & Increasing & 4400 & 1400 & $\begin{array}{c}2935 . \\
4\end{array}$ & $\begin{array}{l}\text { Projections indicate increasing } \\
\text { trend. }\end{array}$ \\
\hline $\begin{array}{l}\text { Total Dissolved Solid } \\
(\mathrm{mg} / \mathrm{L})\end{array}$ & Decreasing & 5800 & 1300 & 4030 & MCL will be reached in 2031. \\
\hline Bicarbonate (mg/L) & Increasing & 13300 & 590 & $\begin{array}{c}4584 . \\
6\end{array}$ & $\begin{array}{l}\text { Projections indicate increasing } \\
\text { trend. }\end{array}$ \\
\hline $\begin{array}{l}\text { Ammonia as } \mathrm{N} \\
(\mathrm{mg} / \mathrm{L})\end{array}$ & Decreasing & 3100 & 16 & 836.5 & $\begin{array}{l}\text { Projections indicate decreasing } \\
\text { trend, observations showed } \\
\text { steady levels. Projected to be } \\
\text { close to zero in } 2014 \text {. }\end{array}$ \\
\hline $\mathrm{pH}$ & Steady & 8 & 7 & 7.48 & Relatively stable. \\
\hline $\begin{array}{l}\text { Vinyl Chloride } \\
(\mu \mathrm{g} / \mathrm{L})\end{array}$ & Decreasing & 3 & 1 & 1.7 & MCL will be reached in 2010 . \\
\hline $\begin{array}{l}\text { 1,4-Dichlorobenzene } \\
(\mu \mathrm{g} / \mathrm{L})\end{array}$ & Decreasing & 12.0 & 1.0 & 6.98 & Already below MCL. \\
\hline $\begin{array}{l}\text { Chlorobenzene } \\
(\mu \mathrm{g} / \mathrm{L})\end{array}$ & Increasing & 15.0 & 7.3 & 11.1 & $\begin{array}{l}\text { Already below MCL. } \\
\text { Although projections indicate } \\
\text { increasing trend, observations } \\
\text { indicated steady trend. }\end{array}$ \\
\hline Benzene $(\mu \mathrm{g} / \mathrm{L})$ & Decreasing & 4.00 & 0.18 & 3.13 & $\begin{array}{l}\text { Projections indicate decreasing } \\
\text { trend, observations showed } \\
\text { steady levels. Projected to } \\
\text { reach MCL in 2030. }\end{array}$ \\
\hline Toluene $(\mu \mathrm{g} / \mathrm{L})$ & Decreasing & 7.6 & 1.0 & 3.39 & Already below MCL. \\
\hline Ethylbenzene $(\mu \mathrm{g} / \mathrm{L})$ & Decreasing & 19.0 & 3.9 & 8.98 & Already below MCL. \\
\hline Xylenes $(\mu \mathrm{g} / \mathrm{L})$ & Decreasing & 28.0 & 5.8 & 13.26 & Already below MCL. \\
\hline Total BTEX $(\mu \mathrm{g} / \mathrm{L})$ & Decreasing & 51.3 & 18.6 & 30.45 & Already below MCL. \\
\hline
\end{tabular}

Anaerobic conditions in landfill provide favorable conditions for corrosion of iron resulting in higher concentrations over time. Bicarbonate formation as a byproduct of bacterial respiration during waste decomposition and the limerock cap system of the landfill contribute to the increasing levels of bicarbonate in leachate. Chlorobenzene is produced during anaerobic biodegradation of 1,4-dichlorobenzene, hence, the increasing trend of chlorobenzene may be due to the declining trend of 1,4-dichlorobenzene. The 
source of these VOCs and other contaminants in leachate are primarily household cleaners and anaerobic biodegradation of the parent compounds as shown in Table 9.

Table 9. Potential sources of contaminants detected in leachate.

\begin{tabular}{|c|c|}
\hline Contaminants & Source \\
\hline Sodium & Sodium is derived from dissolution of salt (Statom et al., 2004) \\
\hline Chloride & $\begin{array}{l}\text { The major sources of chlorine in MSW are paper and plastics. Chlorine is } \\
\text { used directly to make certain products, such as PVC plastics and insulation } \\
\text { and textiles. Chlorine is also used to bleach pulp for papermaking (U.S. } \\
\text { Congress, Office of Technology Assessment, 1989) }\end{array}$ \\
\hline TDS & The major contributors are sodium and chloride in leachate. \\
\hline Iron & Food and beverage cans, wood-waste (Lee et al., 1991). \\
\hline Bicarbonate & $\begin{array}{l}\text { When the waste is decomposed due to the high moisture content, large } \\
\text { amount of bicarbonate is formed as a byproduct of bacterial respiration } \\
\text { (Klinck et al., 1999). }\end{array}$ \\
\hline Ammonium as $\mathrm{N}$ & $\begin{array}{l}\text { Ammonia is released from the waste mainly by decomposition of protein } \\
\text { (Kjeldsen et al., 2002). Under the anaerobic conditions nitrates are reduced } \\
\text { to ammonia (Reinhart et al, 1998) }\end{array}$ \\
\hline Vinyl chloride & $\begin{array}{l}\text { Polyvinyl chloride (PVC) food wrappings, packages, anaerobic degradation } \\
\text { by product of tetrachloroethane, (http://www.epa.gov/OGWDW/t- } \\
\text { voc/vinylchl.htm), 1,2-dichloroethene in landfills will eventually break down } \\
\text { into vinyl chloride (http://www.atsdr.cdc.gov/toxprofiles/tp87-c1.pdf) }\end{array}$ \\
\hline $\begin{array}{l}\text { 1,4- } \\
\text { Dichlorobenzene }\end{array}$ & $\begin{array}{l}\text { Household cleaners (disinfectant, toilet bowl cleaner). Anaerobic } \\
\text { biodegradation byproduct of 1,2,4-trichlorobenzene (Lawrence, 2006; U.S. } \\
\text { Congress, Office of Technology Assessment,1989). }\end{array}$ \\
\hline Chlorobenzene & $\begin{array}{l}\text { Household cleaners (degreaser, destainer) (U.S. Congress, Office of } \\
\text { Technology Assessment,1989). Anaerobic biodegradation by product of } 1.4 \\
\text { dichlorobenzene (Lawrence, 2006) }\end{array}$ \\
\hline $\begin{array}{l}\text { cis-1,2- } \\
\text { Dichloroethylene }\end{array}$ & $\begin{array}{l}\text { Household cleaners, shoe polish (U.S. Congress, Office of Technology } \\
\text { Assessment,1989), anaerobic biodegradation of tetrachloroethene (PCE) } \\
\text { (Lawrence, 2006) }\end{array}$ \\
\hline Benzene & $\begin{array}{l}\text { Household cleaners, varnish, nail polish (U.S. Congress, Office of } \\
\text { Technology Assessment,1989) }\end{array}$ \\
\hline Toluene & $\begin{array}{l}\text { Household cleaners, lubricating oil, brake/clutch/ hydraulic fluid, motor oil, } \\
\text { paint (latex, lacquer thinners), adhesives (microfilm, plastic, leather, fabric, } \\
\text { rubber), nail polish (U.S. Congress, Office of Technology Assessment, } \\
\text { 1989) }\end{array}$ \\
\hline Ethylbenzene & $\begin{array}{l}\text { A solvent for coatings, and in the production of synthetic rubber and } \\
\text { cellulose acetate, thinner, gasoline (www.eco-usa.net/toxics/ethbenz.shtml, } \\
\text { http://www.epa.gov/OGWDW/dwh/t-voc/ethylben.html) }\end{array}$ \\
\hline Xylenes & $\begin{array}{l}\text { Transmission fluid, engine treatment (degreaser), paint (latex, non-latex, } \\
\text { lacquer thinners), adhesives (microfilm, fabric), nail polish (U.S. Congress, } \\
\text { Office of Technology Assessment,1989; } \\
\text { http://www.netspeed.com.au/rdi/cas/xylene.htm ) }\end{array}$ \\
\hline Total BTEX & $\begin{array}{l}\text { Benzene, toluene, ethlybenzene, and xylene compounds typical present in } \\
\text { gasoline (Lawrence, 2006) }\end{array}$ \\
\hline
\end{tabular}


Table 10 compares the accuracy of the time series projections for selected parameters in leachate. The time series model in general provided an adequate forecast for future planning purposes. Table 11 presents the accuracy of the projections for the VOC levels in leachate. The projections for the VOCs monitored were also adequate for planning purposes. The model projections for 1,4 dichlorobenzene were relatively less accurate in comparison to the projections for vinyl chloride and chlorobenzene. Among the BTEX compounds, benzene showed the most adequate fit for the time series projections; toluene had the highest mean absolute percentage error (MAPE), and xylene had the highest mean absolute deviation (MAD) and mean squared deviation (MSD).

Table 10. The accuracy of time series projections for selected leachate quality parameters.

\begin{tabular}{|l|c|c|c|}
\hline Parameter & $\begin{array}{c}\text { Mean Absolute } \\
\text { Percentage Error } \\
\text { (MAPE) \% }\end{array}$ & $\begin{array}{c}\text { Mean Absolute } \\
\text { Deviation } \\
\text { (MAD) }\end{array}$ & $\begin{array}{c}\text { Mean Squared } \\
\text { Deviation } \\
\text { (MSD) }\end{array}$ \\
\hline Leachate quantity $\left(\mathrm{m}^{3} / \mathrm{month}\right)$ & 57 & 219.5 & 89763.2 \\
\hline Sodium $(\mathrm{mg} / \mathrm{L})$ & 23.1 & 239.8 & 75812.5 \\
\hline Chloride $(\mathrm{mg} / \mathrm{L})$ & 7.72 & 67.46 & 6150.5 \\
\hline Iron $(\mu \mathrm{g} / \mathrm{L})$ & 23 & 533 & 558883 \\
\hline Total Dissolved Solids $(\mathrm{mg} / \mathrm{L})$ & 7 & 284 & 125589 \\
\hline Bicarbonate $(\mathrm{mg} / \mathrm{L})$ & 10 & 381 & 204077 \\
\hline Ammonia as N $(\mathrm{mg} / \mathrm{L})$ & 9.71 & 699 & 902979 \\
\hline $\mathrm{pH}$ & 2.81 & 0.213 & 0.077 \\
\hline
\end{tabular}

Table 11. The accuracy of time series projections of selected VOCs in leachate.

\begin{tabular}{|l|c|c|c|}
\hline Parameter & $\begin{array}{c}\text { Mean Absolute } \\
\text { Percentage Error } \\
(\text { MAPE) } \%\end{array}$ & $\begin{array}{c}\text { Mean Absolute } \\
\text { Deviation } \\
(\text { MAD })\end{array}$ & $\begin{array}{c}\text { Mean Squared } \\
\text { Deviation } \\
(\text { MSD })\end{array}$ \\
\hline Vinyl Chloride $(\mu \mathrm{g} / \mathrm{L})$ & 41.44 & 0.62 & 0.53 \\
\hline 1,4 Dichlorobenzene $(\mu \mathrm{g} / \mathrm{L})$ & 80.08 & 2.22 & 7.63 \\
\hline Chlorobenzene $(\mu \mathrm{g} / \mathrm{L})$ & 14.23 & 1.49 & 2.75 \\
\hline Benzene $(\mu \mathrm{g} / \mathrm{L})$ & 12.09 & 0.39 & 0.20 \\
\hline Toluene $(\mu \mathrm{g} / \mathrm{L})$ & 42.14 & 0.88 & 1.50 \\
\hline Ethylbenzene $(\mu \mathrm{g} / \mathrm{L})$ & 36.36 & 2.60 & 9.51 \\
\hline Xylene $(\mu \mathrm{g} / \mathrm{L})$ & 33.15 & 3.31 & 16.61 \\
\hline Total BTEX $(\mu \mathrm{g} / \mathrm{L})$ & 21.32 & 5.41 & 50.5 \\
\hline
\end{tabular}




\subsection{Landfill Gas (LFG) Module}

The purpose of the Landfill Gas (LFG) Module is to evaluate whether LFG monitoring can be changed, optimized, reduced or discontinued. For this reason, the LFG module was divided into two parts:

1. Evaluation of the LFG production trend with available data, and

2. Comparison of the LFG trend using Landfill Gas Emissions Model (LandGEM) software.

The results of the gas module were used for the following:

1. Analysis of the landfill gas production trend overtime,

2. Estimation of the remaining LFG potential, and

3. Decision to optimize/reduce or discontinue the LFG monitoring.

\subsubsection{Landfill Gas Trend Analysis}

Landfill gas generated is collected by the landfill gas management system and eliminated through an enclosed flare. There are 33 gas extraction wells. The current landfill gas flow rate entering the enclosed flare is approximately 200 to 250 standard cubic feet per minute ( $\mathrm{scfm}$ ) with a methane concentration of approximately $40 \%$ to $50 \%$. The north mound generates enough gas to operate the flare approximately 1 to 1.5 hours per day. Gas pressure, gas composition, oxygen concentration and gas temperature at each gas extraction well/trench and flare are recorded on a monthly basis. The landfill gas data are available from 2004 to 2008. The LFG data plotted over time show that the amount of LFG generated is decreasing shown in Figure 27. Figure 28 shows the monthly landfill gas generation trend. The methane generation over time also showed a decreasing trend presented in Figure 29. 


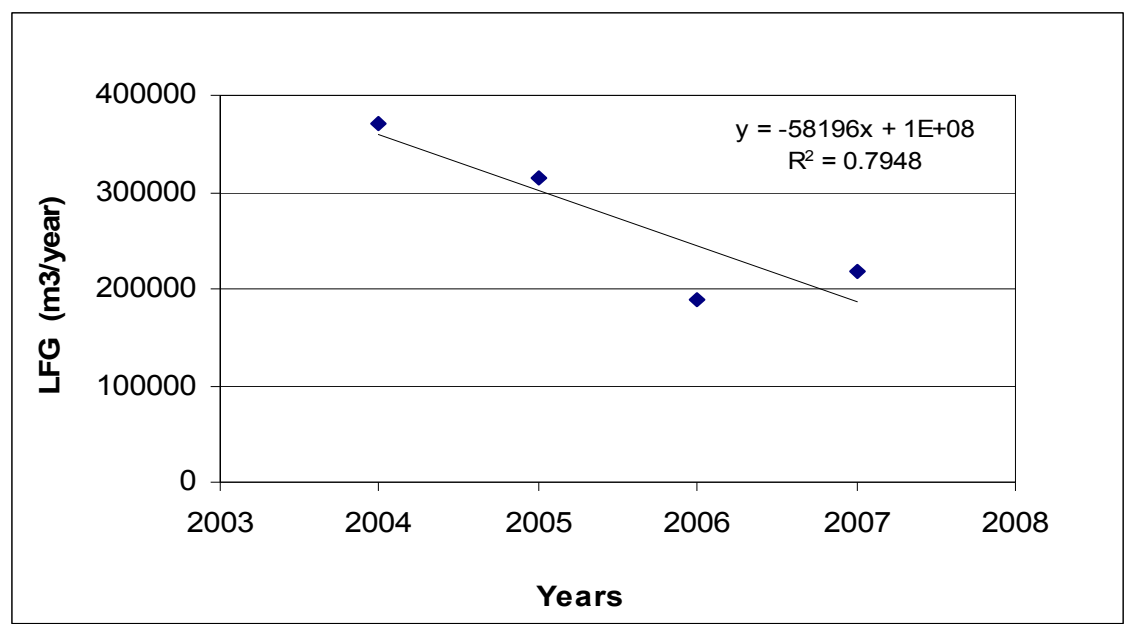

Figure 27. Annual landfill gas generation trend.

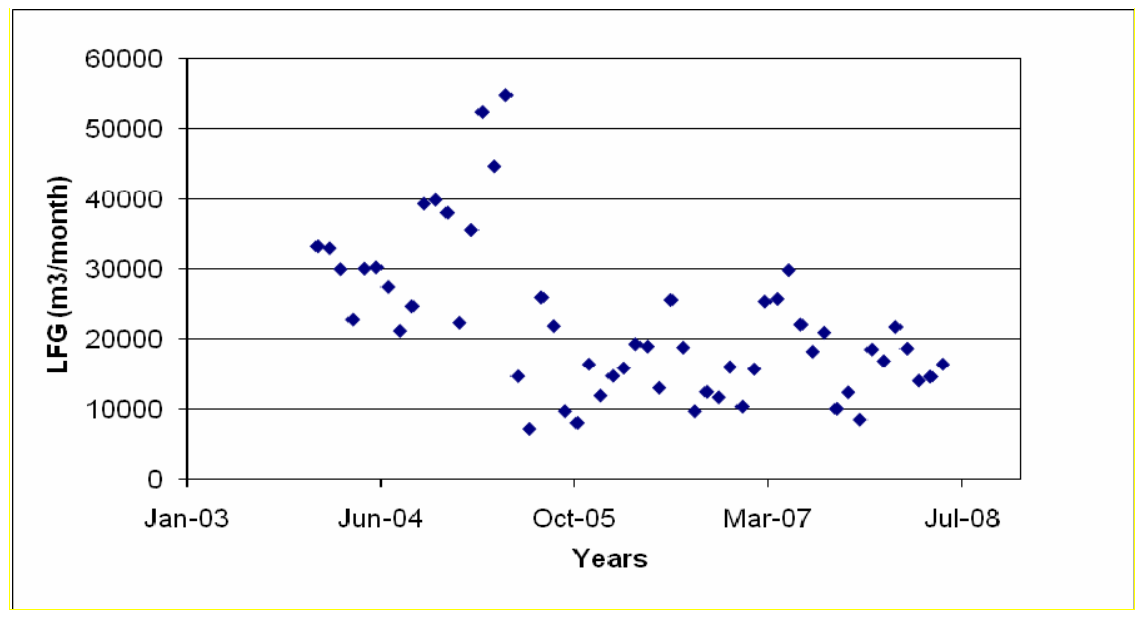

Figure 28. Monthly landfill gas generation trend.

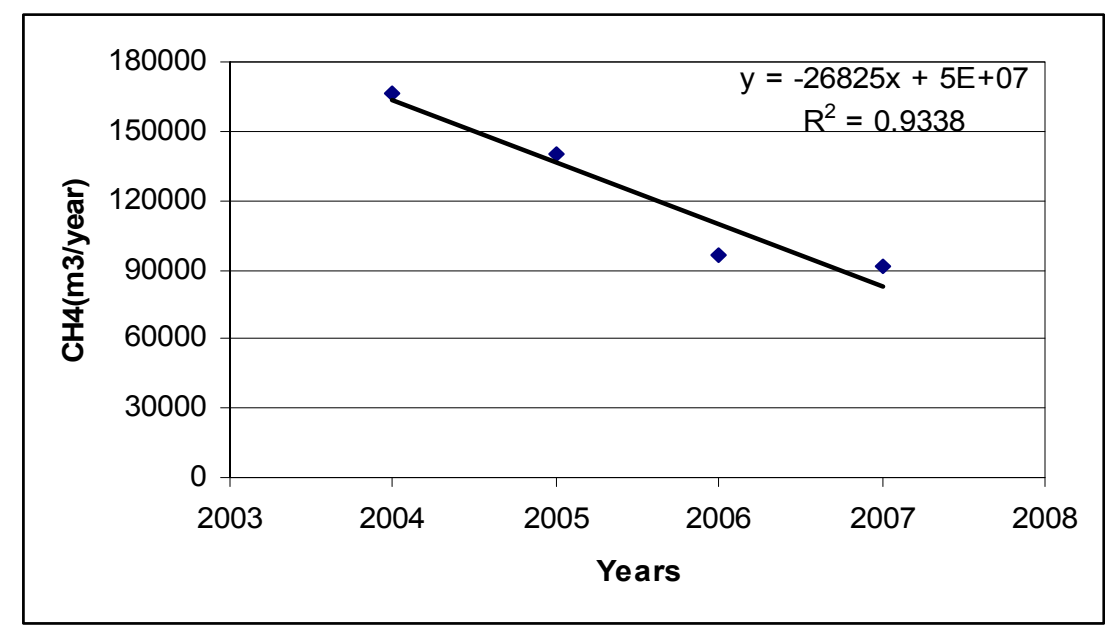

Figure 29. Yearly methane generation trend. 


\subsubsection{Remaining Gas Generation Potential Analysis}

The Davie Landfill site is still generating LFG. Therefore, the remaining gas generation potential was estimated based on the decreasing trend observed for gas production. The estimation of remaining LFG allows optimization of monitoring frequency of the gas generation rate. Calculation of the remaining LFG requires estimation of the total LFG generation potential of the waste. With the available data (2004-2008), total LFG calculation could not be calculated. LandGEM software was used to estimate the closest values for LFG and methane generation rates. LandGEM relies on several model parameters to estimate landfill emissions. These include:

- Opening and closing date of landfill,

- Total waste placed in landfill,

- Methane generation rate $(k)$,

- Potential methane generation capacity $(L o)$, and

- NMOC concentrations and methane content.

Davie landfill accepted municipal waste from 1975 to 1987 . The waste quantity deposited over the years is presented in Table 12. A total of 2,695,628 tons waste was placed in the landfill.

Table 12. Waste in placed to Davie Landfill during operation time

\begin{tabular}{|c|c|c|c|}
\hline Years & Waste (tons) & Years & Waste (tons) \\
\hline $1975-1979$ & 600000 & 1984 & 300677 \\
\hline 1980 & 115122 & 1985 & 281195 \\
\hline 1981 & 241706 & 1986 & 308185 \\
\hline 1982 & 229106 & 1987 & 305000 \\
\hline 1983 & 314637 & & \\
\hline
\end{tabular}




\subsubsection{Methane Generation Rate (k) Calculations}

The methane generation rate $(\mathrm{k})$ is primarily a function of four factors:

- Moisture content of the waste mass,

- Availability of nutrients for microorganisms that break down the waste to form methane and carbon dioxide, and

- $\mathrm{pH}$ and temperature of the waste mass.

(http://www.xyta.gr/support/landfilldesign/answers.aspx?answer=ec239b28)

The USEPA developed a methodology for determining landfill gas generation based on a first-order degradation model as follows:

$$
\mathrm{Q}=2 \mathrm{~kL}_{\mathrm{o}} \mathrm{M}_{\mathrm{i}} \mathrm{e}^{-\mathrm{kt}}
$$

Where;

$\mathrm{Q}=$ total annual gas production rate $\left(\mathrm{m}^{3} /\right.$ year $)$,

$\mathrm{L}_{\mathrm{o}}=$ methane generation potential ( $\mathrm{m}^{3}$ methane/MG of waste),

$\mathrm{k}=$ decay coefficient $\left(\right.$ year $\left.^{-1}\right)$,

$\mathrm{M}_{\mathrm{i}}=$ waste in place $(\mathrm{MG})$ and

$\mathrm{t}=$ age of waste (year).

(Faour et al., 2007)

For calculation of $\mathrm{k}$, the formula can be rewritten as follows:

$$
\ln Q=\ln (2 \mathrm{k} \text { Lo } \mathrm{M})-\mathrm{k} \mathrm{t}
$$

The value of $\mathrm{k}$ can be calculated as shown in Figure 30. 


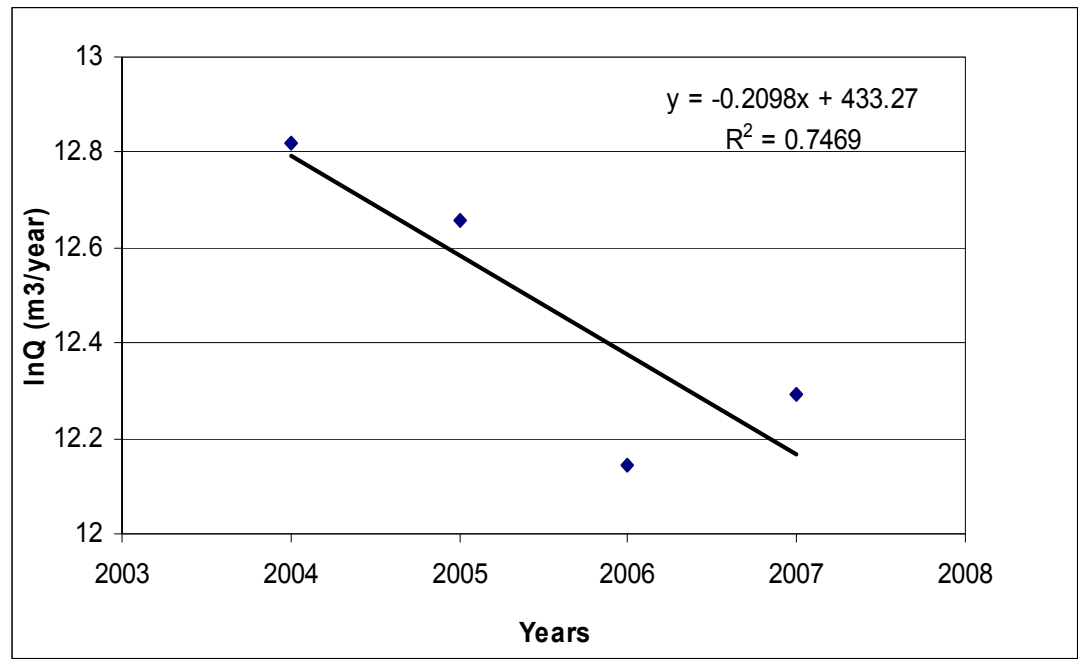

Figure 30. Methane generation rate $(\mathrm{k})$ calculation.

Based on the slope of the line, $\mathrm{k}$ was estimated as 0.21 per year. The higher the value of $\mathrm{k}$, the faster the methane generation rate increases and then decays over time.

In the absence of specific values of data default values are provided in LandGEM. LandGEM default values are mentioned in Table $13 . \mathrm{L}_{\mathrm{o}}$ and $\mathrm{k}$ values may vary depending on the mode of operation of landfills.

Table 13. Default Lo and $\mathrm{k}$ values used in LandGEM (EPA, 2005).

\begin{tabular}{|c|c|c|}
\hline & $\mathbf{L}_{\mathbf{0}}, \mathbf{m}^{\mathbf{3}} / \mathbf{m e g a g r a m s}$ & $\mathbf{k}, \mathbf{y r}^{\mathbf{- 1}}$ \\
\hline CAA & 170 & 0.05 \\
\hline AP-42 & 100 & 0.04 \\
\hline Bioreactor & 96 & 0.25 \\
\hline
\end{tabular}

\subsubsection{Potential Methane Generation Capacity (Lo)}

The potential methane generation capacity $\left(\mathrm{L}_{\mathrm{o}}\right)$, depends on the type and composition of waste, the higher the cellulose contents of the waste, the higher the value of $\mathrm{L}_{\mathrm{o}}$. The value of $\mathrm{L}_{\mathrm{o}}: 22 \mathrm{~m}^{3} / \mathrm{Mg}$ was estimated by using LandGEM model.

\subsubsection{Methane Content}

Methane content of LFG was found to be about $45 \%$, based on monthly monitoring of the gas composition shown in Table 14. 
Table 14. Gas composition.

\begin{tabular}{|l|c|}
\hline Constituent & Percentage in gas \\
\hline Methane & $45 \%$ \\
\hline Oxygen & $1.36 \%$ \\
\hline Carbon dioxide & $30 \%$ \\
\hline
\end{tabular}

\subsubsection{Comparison of LandGEM with real data}

LandGEM software was run to compare the estimated gas data with the actual gas monitoring data. The input data used for running the software are shown in Table 15.

Table 15. LandGEM input data.

\begin{tabular}{|l|l|l|}
\hline \multicolumn{1}{|c|}{ LANDFILL CHARACTERISTICS } & \multicolumn{1}{c|}{ Value } & \multicolumn{1}{c|}{ Units } \\
\hline Landfill Open Year & 1975 & \\
\hline Landfill Closure Year (with 80-year limit) & 1987 & \\
\hline Actual Closure Year (without limit) & 1987 & \\
\hline Have Model Calculate Closure Year? & No & \\
\hline Waste Design Capacity & & Megagrams \\
\hline MODEL PARAMETERS & & \\
\hline Methane Generation Rate, $\mathrm{k}$ & 0.21 & $\mathrm{year}^{-1}$ \\
\hline Potential Methane Generation Capacity, $\mathrm{L}_{\mathrm{o}}$ & 22 & $\mathrm{~m}^{3} / \mathrm{Mg}$ \\
\hline NMOC Concentration & 4,000 & $\mathrm{ppmv}$ as hexane \\
\hline Methane Content & 45 & $\%$ by volume \\
\hline
\end{tabular}

Running LandGEM software gave reasonably close values to actual field data collected from the landfill site as shown in Table 16.

Table 16. Comparison LandGEM to real data.

\begin{tabular}{|c|c|c|c|c|c|c|}
\hline Year & $\begin{array}{c}\text { Real Data } \\
\mathbf{L F G} \\
\mathbf{m}^{\mathbf{3}} / \mathbf{y e a r}\end{array}$ & $\begin{array}{c}\mathbf{C H}_{\mathbf{4}} \\
\mathbf{m}^{\mathbf{3}} / \mathbf{y e a r}\end{array}$ & $\begin{array}{c}\text { LandGEM } \\
\mathbf{L F G} \mathbf{m}^{\mathbf{3}} / \mathbf{y e a r}\end{array}$ & $\begin{array}{c}\mathbf{C H}_{\mathbf{4}} \\
\mathbf{m}^{\mathbf{3}} / \mathbf{y e a r}\end{array}$ & $\begin{array}{c}\mathbf{C H}_{4} \\
\text { \%Difference }\end{array}$ & $\begin{array}{c}\text { LFG } \\
\text { \%Difference }\end{array}$ \\
\hline 2004 & 370232.5 & 166098.8 & 380454.1 & 171204.3 & 3 & 2.7 \\
\hline 2005 & 314018.2 & 139673.8 & 308390.1 & 138775.5 & 0.6 & 1.8 \\
\hline 2006 & 188392.5 & 96618.44 & 249976.1 & 112489.3 & 14.1 & 24.6 \\
\hline 2007 & 218121.6 & 91035.01 & 202626.7 & 91182.03 & 0.2 & 7.6 \\
\hline
\end{tabular}




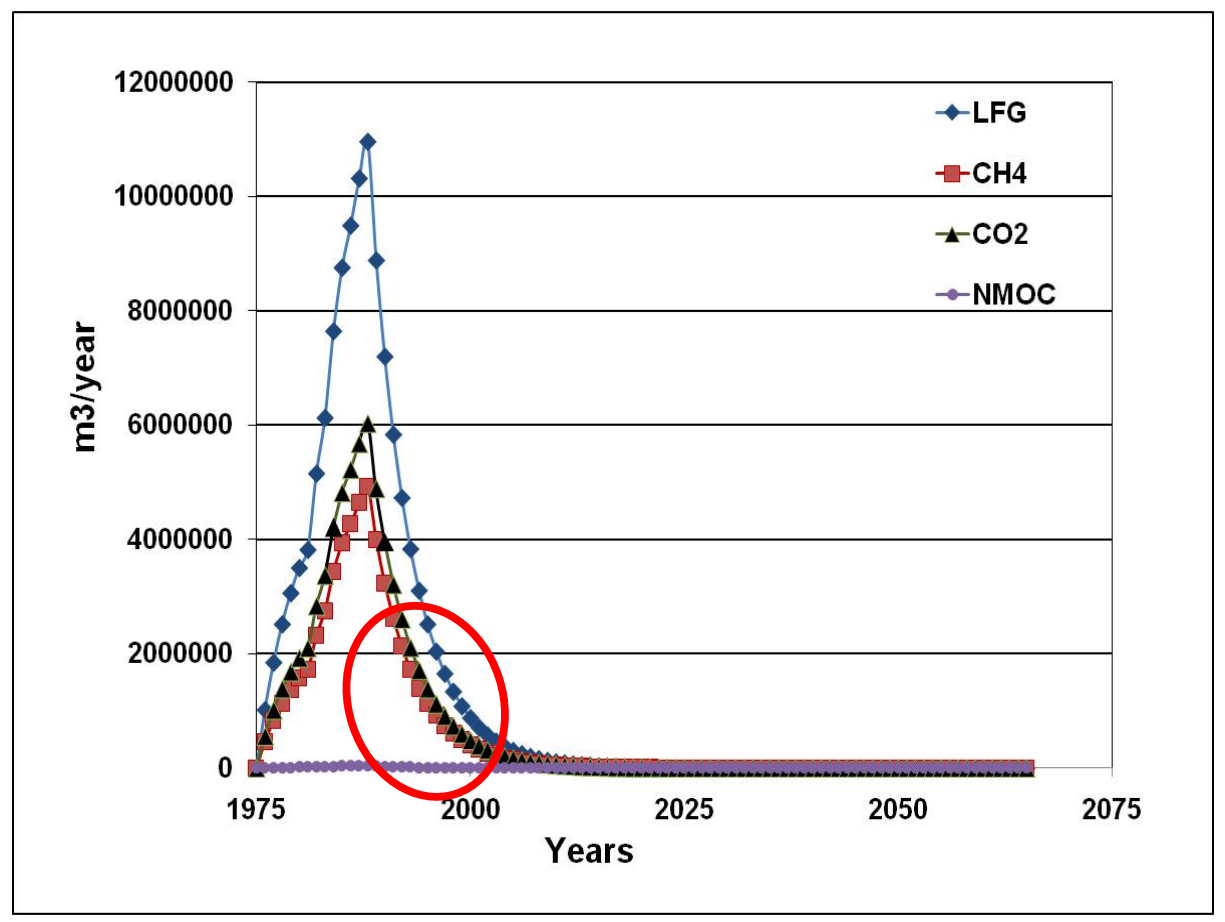

Figure 31. Total gas values (LandGEM).

Estimated total gas quantity and gas constituents overtime have similar decreasing trend which have been also observed from the actual data as shown in Figure 31 . Total LFG $\left(121,068,047 \mathrm{~m}^{3}\right)$ and current LFG $\left(120,365,178 \mathrm{~m}^{3}\right)$ were estimated by using LandGEM model.

\section{Remaining LFG potential (LFG remain \% of total)}

$\mathrm{LFG}_{\text {remain }}$ is an estimation of the quantity of gas to be emitted by the landfill in the future, which is proportional to the remaining biodegradability of the waste. Use of available gas generation data (from LFG monitoring) or LandGEM is recommended for estimation of $\mathrm{LFG}_{\text {remain }}$ LFG remain can be estimated by the following equation.

$L F G_{\text {Re } \text { maining }}=\frac{L F G_{\text {Total }}-L F G_{\text {Already } \text { Pr oduced }}}{L F G_{\text {Total }}} \%$ 
where

$$
\begin{array}{ll}
\mathrm{LFG}_{\text {remain }} & =\text { Remaining } \mathrm{LFG} \text { producing g potential, } \% \\
\mathrm{LFG}_{\text {total }} & =\text { Total gas produced from the waste in place, } \mathrm{m}^{3} \\
\mathrm{LFG}_{\text {alreadyproduced }} & =\mathrm{LFG} \text { produced till the time of evaluation, } \mathrm{m}^{3}
\end{array}
$$

Based on the results, remaining LFG is about $0.5 \%$ which indicates very low gas generation potential from the landfill (which is less than the recommended $(<10 \%)$ in the methodology for optimization of gas monitoring/collection system). Projected total LFG is going be $1000 \mathrm{~m}^{3} /$ year after the year 2032 .

\subsubsection{Discussion about Landfill Gas module}

The estimated LFG from the landfill was based on the flared gas data. The measured total LFG, methane content and potential methane generation capacity $\left(\mathrm{L}_{0}=22\right.$ $\mathrm{m}^{3} / \mathrm{MG}$ ) is less than expected based on the literature review. On the other hand, calculated methane generation Rate $\left(\mathrm{k}=0.21 \mathrm{year}^{-1}\right)$ is higher than literature values. According to Faour (2007), $\mathrm{k}$ can be higher for dry cells if the ultimate gas production is low. Poor capping is the most significant reason for miscalculations. According to US EPA's "Compilation of air pollution emission factors, Report AP-42" (USEPA, 1995), researchers and practitioners have estimated the gas collection efficiencies to be typically in the range of 60 to $85 \%$.

\subsection{Groundwater Module}

The purpose of the Groundwater Module is to determine whether the groundwater monitoring program can be optimized, or continued/discontinued. The evaluations performed in the groundwater module are based on the outcomes of leachate module and 
landfill gas module which impact adversely groundwater via leachate releases or subsurface LFG migration. The first step of the module was frequency determination of groundwater contaminant. The second step was comparison of the contaminant concentration to Maximum Contamination Levels (MCLs) recommended by federal or state agencies based on the EPA's Statistical Analysis of Ground-Water Monitoring Data at RCRA Facilities Interim Final Guidance recommendation. And the final step was to identify the trend for contaminants of concern. The groundwater module was used for the following objectives:

1. Evaluation of the contaminant of concern concentration overtime and comparison with MCLs,

2. Estimation of trends for the contaminant of concern, and

3. Decision to continue/discontinue monitoring of the contaminants of concern.

There are 22 groundwater monitoring wells in the Davie Landfill. Well locations and numbers are shown in Figure 32. Samples taken from different depth for each monitoring well (MW) are shown in Table 17. The groundwater is monitored semiannually (April and September). Availability of the sampling data is from April 2001 to April 2008. Groundwater direction is southeasterly. A total of 53 parameters have been monitored. Among these parameters 37 parameters are non-detected parameters, 5 parameters are always above Maximum Contaminant Level (MCL) and 11 parameters are below the MCL shown in Table 18. Most frequently detected contaminants are Iron, Ammonia as N, Total Dissolved Solid (TDS), Sodium and Turbidity and least detected contaminants are xylene and cadmium shown in Table 19 and Figure 33. 
Table 17. Depth of groundwater monitoring wells.

\begin{tabular}{|l|l|l|l|l|l|l|l|l|l|l|l|l|l|}
\hline $\begin{array}{l}\text { Well } \\
\text { no }\end{array}$ & $\begin{array}{l}\text { Depth } \\
\text { (ft) }\end{array}$ & $\begin{array}{l}\text { Well } \\
\text { no }\end{array}$ & $\begin{array}{l}\text { Depth } \\
\text { (ft) }\end{array}$ & $\begin{array}{l}\text { Well } \\
\text { no }\end{array}$ & $\begin{array}{l}\text { Depth } \\
\text { (ft) }\end{array}$ & $\begin{array}{l}\text { Well } \\
\text { no }\end{array}$ & $\begin{array}{l}\text { Depth } \\
\text { (ft) }\end{array}$ & $\begin{array}{l}\text { Well } \\
\text { no }\end{array}$ & $\begin{array}{l}\text { Depth } \\
\text { (ft) }\end{array}$ & $\begin{array}{l}\text { Well } \\
\text { no }\end{array}$ & $\begin{array}{l}\text { Depth } \\
\text { (ft) }\end{array}$ & $\begin{array}{l}\text { Well } \\
\text { no }\end{array}$ & $\begin{array}{l}\text { Depth } \\
\text { (ft) }\end{array}$ \\
\hline $\mathbf{3}$ & 38 & $\mathbf{2 2}$ & 34 & $\mathbf{7}$ & 37 & $\mathbf{2 1}$ & 35 & $\mathbf{1 1}$ & 31 & $\mathbf{8}$ & 35 & $\mathbf{9}$ & 36 \\
& 58 & & 60 & & 59 & & 62 & & 57 & & 59 & & 59 \\
& 110 & & 91 & & 84 & & 85 & & 75 & & 72 & & 93 \\
\hline
\end{tabular}

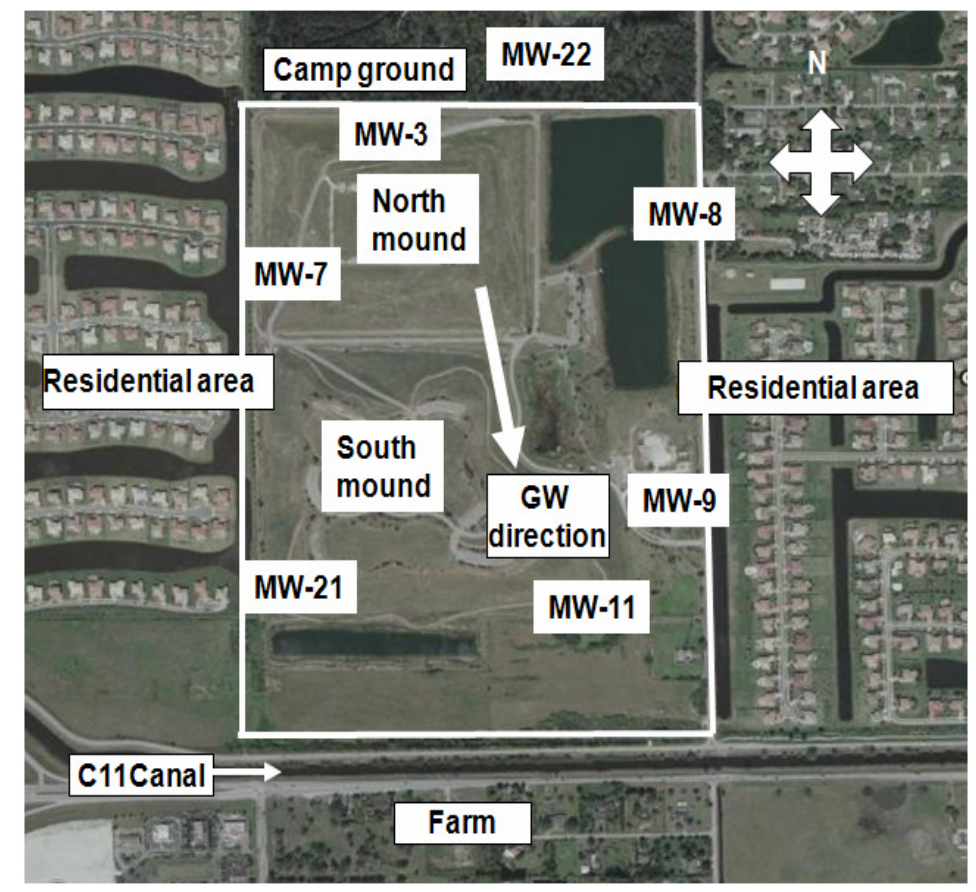

Figure 32. Davie Landfill groundwater well locations and landfill boundaries.

Table 18. Parameters of interest in groundwater.

\begin{tabular}{|l|l|}
\hline Below MCL & Above MCL \\
\hline 1,4-Dichlorobenzene & Sodium \\
\hline Chlorobenzene & Iron \\
\hline 1,2-Dichloroethylene & Total Dissolved Solids \\
\hline Methyl Chloride & Ammonium as N \\
\hline Xylenes & Vinyl Chloride \\
\hline Methyl-tert-butyl ether (MTBE) & Coliform \\
\hline Arsenic & \\
\hline Cadmium & \\
\hline Chromium & \\
\hline Zinc & \\
\hline
\end{tabular}


Table 19. Detection frequency of contaminants in groundwater.

\begin{tabular}{|l|c|}
\hline Compound & $\begin{array}{c}\text { Frequency } \\
\text { (\%) }\end{array}$ \\
\hline Chlorobenzene & 18.2 \\
\hline $1,4-$ & 7.0 \\
Dichlorobenzene & 1.8 \\
\hline Methyl chloride & \\
\hline $\begin{array}{l}\text { Methyltert-Butyl } \\
\text { Ether }\end{array}$ & 2.7 \\
\hline Xylene & 0.3 \\
\hline Vinyl Chloride & 3.0 \\
\hline $1,2-$ & \\
Dichloroethylene & 0.9 \\
\hline Ammonia as N & 100.0 \\
\hline Arsenic & 0.9 \\
\hline Cadmium & 0.3 \\
\hline Chromium & 1.8 \\
\hline Iron & 100.0 \\
\hline Sodium & 100.0 \\
\hline Zinc & 31.8 \\
\hline Dissolved Solid & 100.0 \\
\hline Coliform & 20.6 \\
\hline Turbidity & 100.0 \\
\hline
\end{tabular}

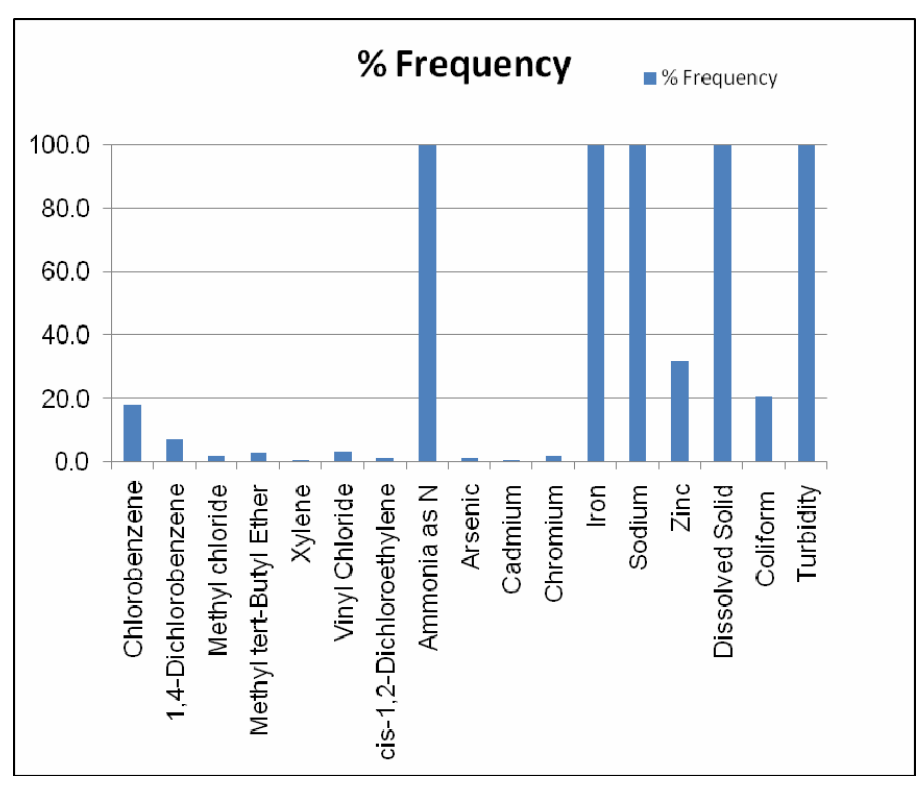

Figure 33. Detected contaminants frequency at Davie Landfill.

\subsubsection{Parameters above MCL}

Iron, ammonia as $\mathrm{N}$, total dissolved solid (TDS), sodium and turbidity were always above the MCL and detected in all groundwater monitoring wells. Vinyl chloride has been detected only at monitoring well (MW) number 11.

Iron: Measured iron levels were between $2-9300 \mu \mathrm{g} / \mathrm{L}$ in all groundwater wells. Figure 34 presents the iron concentration for each GW monitoring well. Iron concentrations in up-gradient wells were between 2000-6000 $\mu \mathrm{g} / \mathrm{L}$ and in down-gradient wells were between $2000-4000 \mu \mathrm{g} / \mathrm{L}$ except for the monitoring well number 11 . This well always had high concentrations and some correlation with MW 3. The presence of high concentrations of ferrous iron reflects reducing conditions in groundwater. Under these conditions, chemicals such as nitrate and possibly some chlorinated solvents are degraded, while some petroleum hydrocarbons persist (http://www.seagrant.umn.edu). 


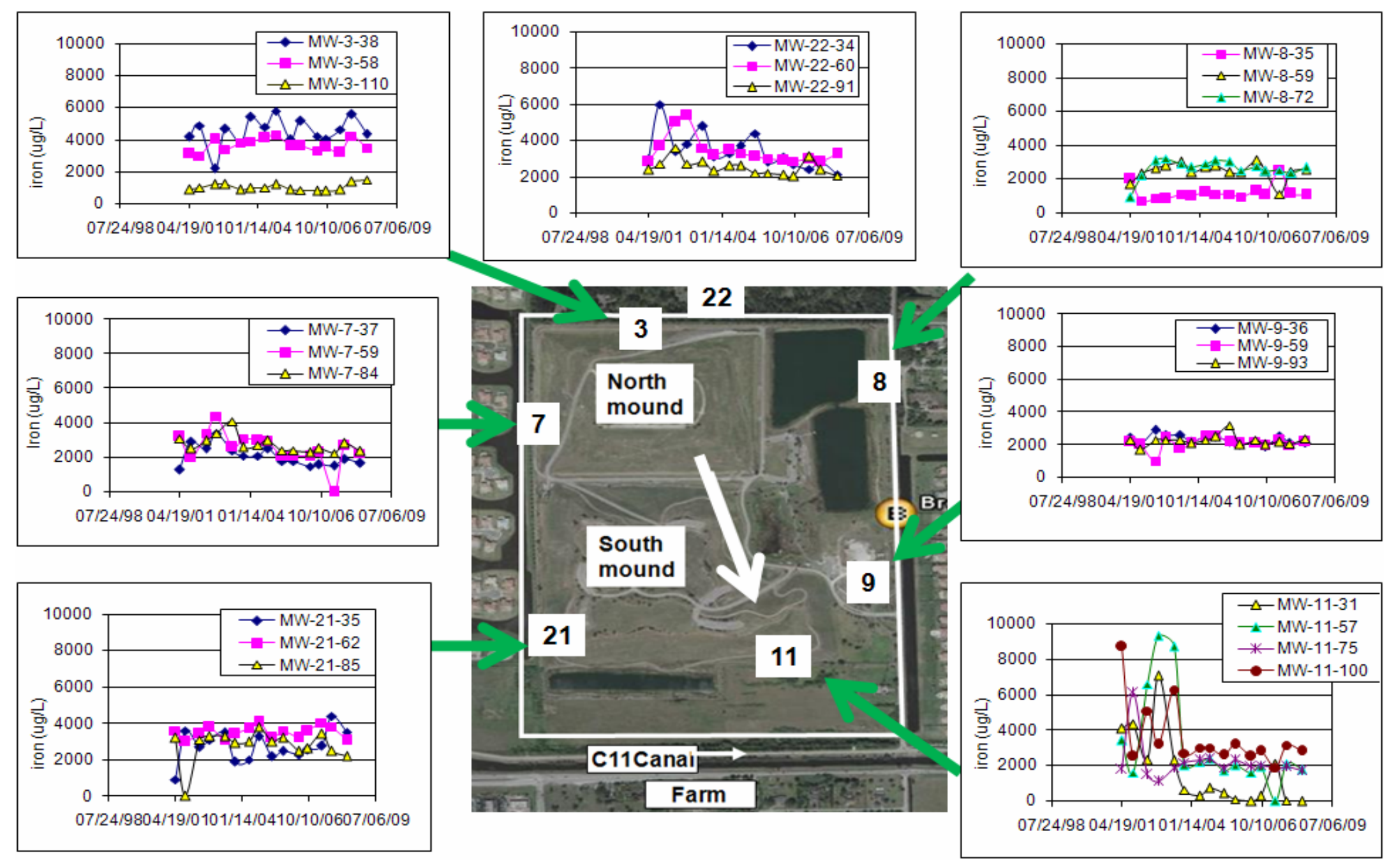

Figure 34. Iron concentration in all groundwater monitoring wells. 
Ammonia as N: Measured ammonia levels as $\mathrm{N}$ concentration were between $0-160 \mathrm{mg} / \mathrm{L}$ in all GW monitoring wells. Ammonia as N concentrations have been detected in MW 3 and 11. MW 3 is up gradient of the GW and MW 11 is down gradient of the southeasterly GW direction. Ammonia is very soluble in water and is extremely toxic for the aquatic ecosystem, especially for fish, at concentrations ranging from 0.53 to 22.8 $\mathrm{mg} / \mathrm{L}$ shown in Figure 35. Its toxicity increases with decreasing of $\mathrm{pH}$ value and temperature (http://www.idm.gov.vn/Nguon_luc/Xuat_ban/2005/B25/b43.htm).

Vinyl Chloride: Vinyl chloride has been detected consistently in one down gradient well (MW 11) during January 1991 to April 2008 at concentrations between 0.5- 4.1 $\mu \mathrm{g} / \mathrm{L}$. Vinyl chloride levels showed a steady trend as presented in Figure 36. Vinyl chloride is the one of priority trace compounds often detected in landfill gas (Shafi et al., 2005). The EPA and the National Toxicology Program (NTP) considers vinyl chloride as a carcinogenic compound (ATSDR 2006). In anaerobic conditions, vinyl chloride degradation occurs slowly.

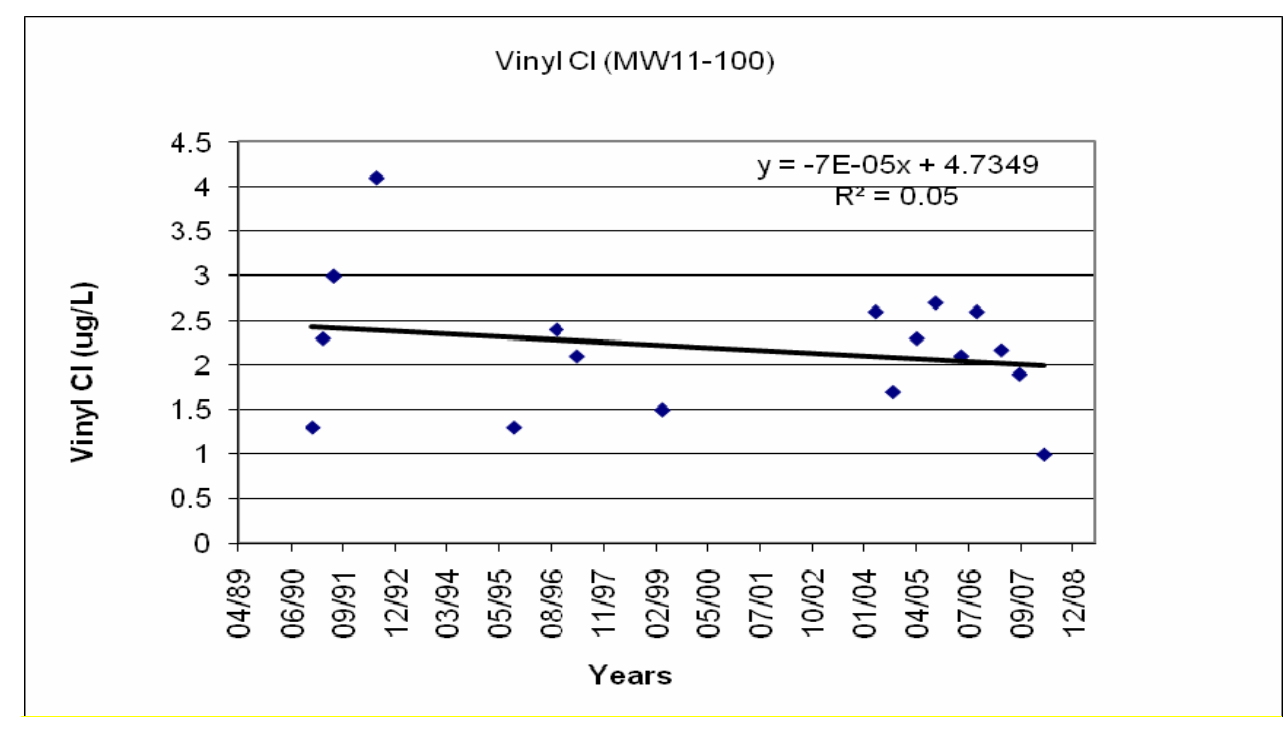

Figure 36. Vinyl Chloride concentration in MW11-100. 

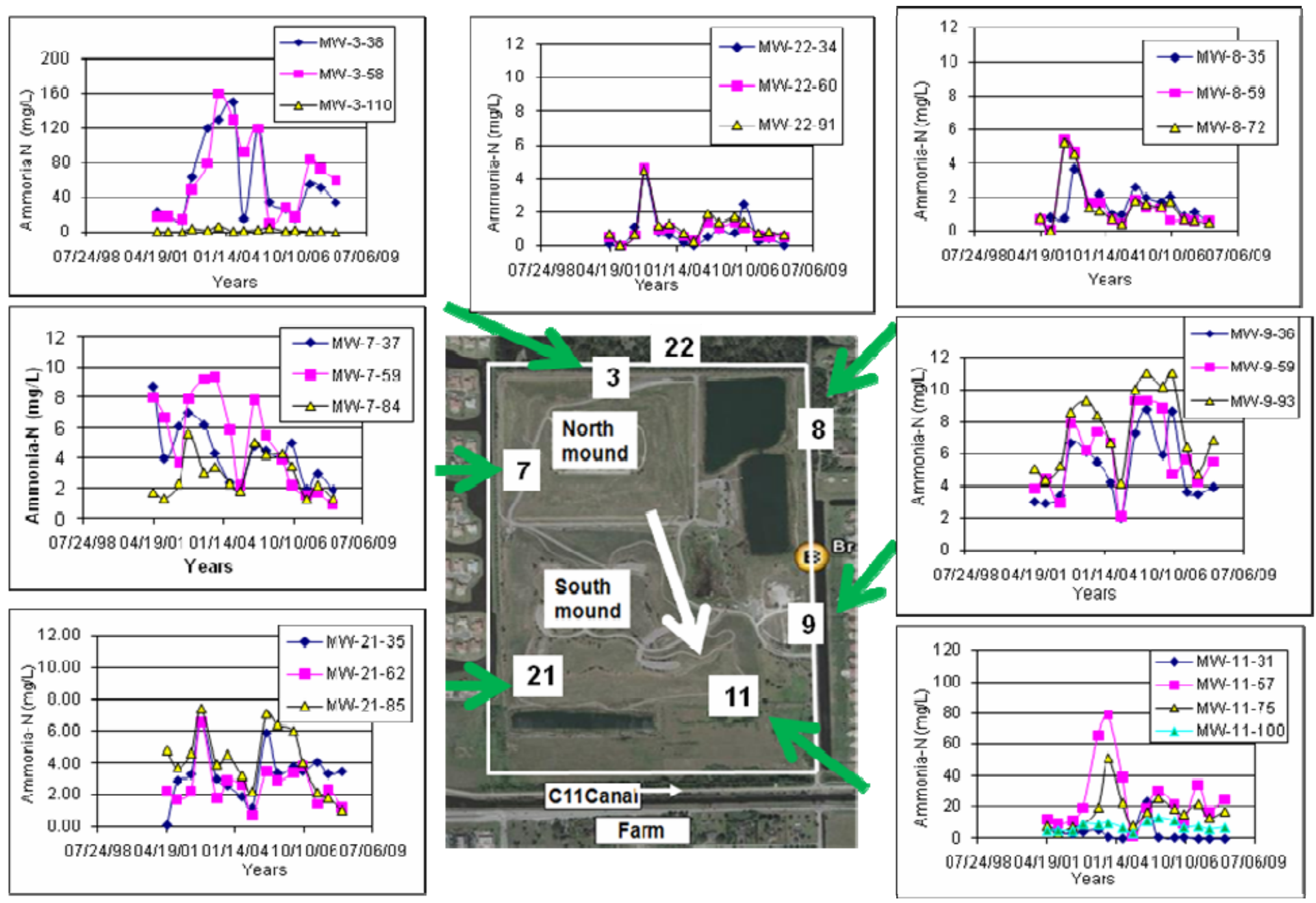

Figure 35. Ammonia as N concentration in MW11-100. 


\subsubsection{Parameters below MCL - Organics}

1,4-Dichlorobenzene, chlorobenzene, 1,2-dichloroethylene, methyl chloride, xylenes and methyl-tert-butyl ether (MTBE) were detected in groundwater monitoring wells as shown in Figure 37. The concentrations of these organic compounds never exceed MCL in the groundwater. The trends of these contaminants are declining both in leachate and groundwater.

Chlorobenzene: Measured chlorobenzene levels were between $0.5-15 \mu \mathrm{g} / \mathrm{L}$ in all GW monitoring wells. Chlorobenzene concentrations never exceeded MCL. Continuous and moderately high levels of chlorobenzene were seen in MW 3 and 11 as shown in Figure 38. Chlorobenzene is slowly degrades in water (http://www.epa.gov)
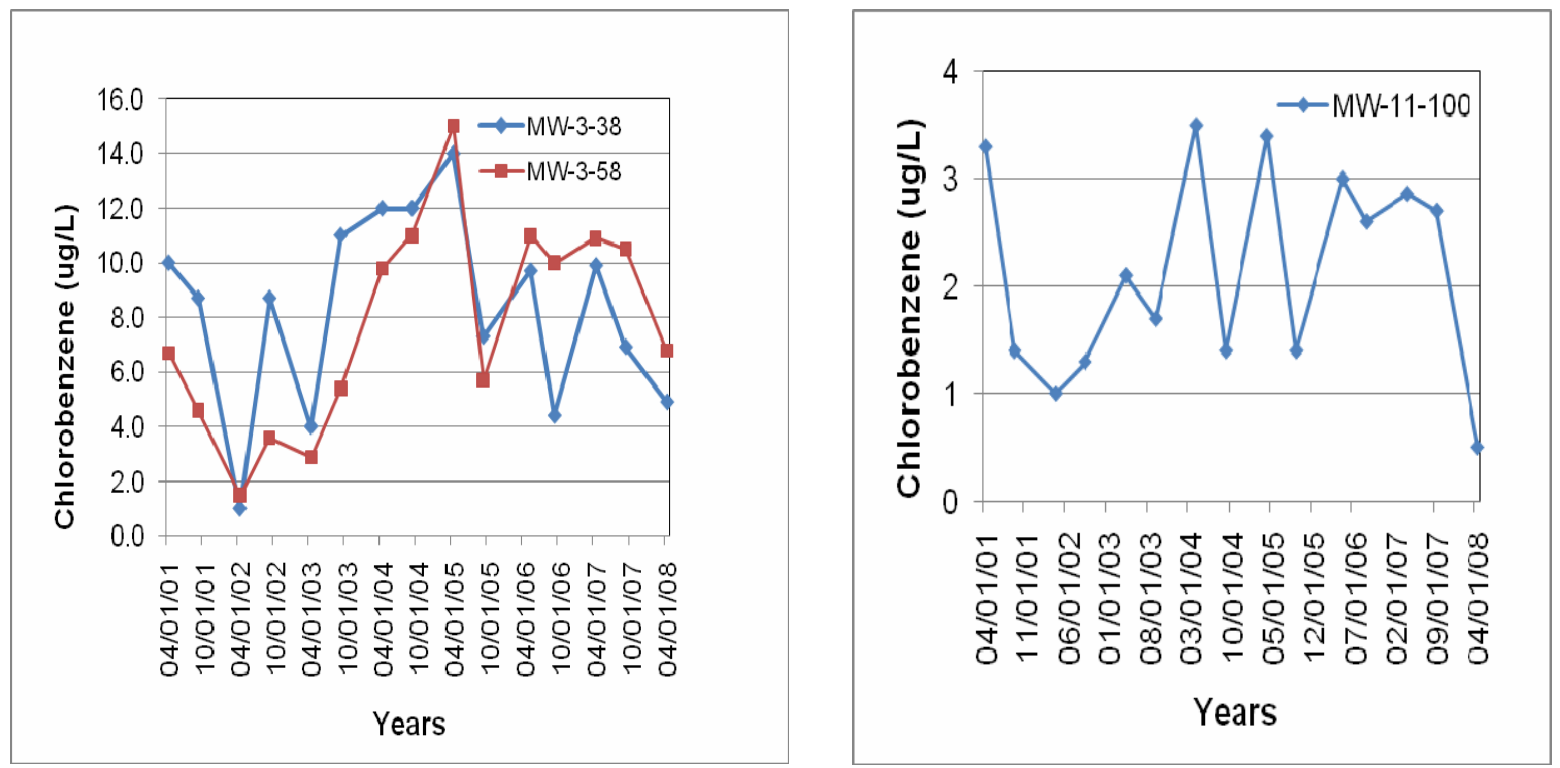

Figure 38. Chlorobenzene concentrations at Davie Landfill. 


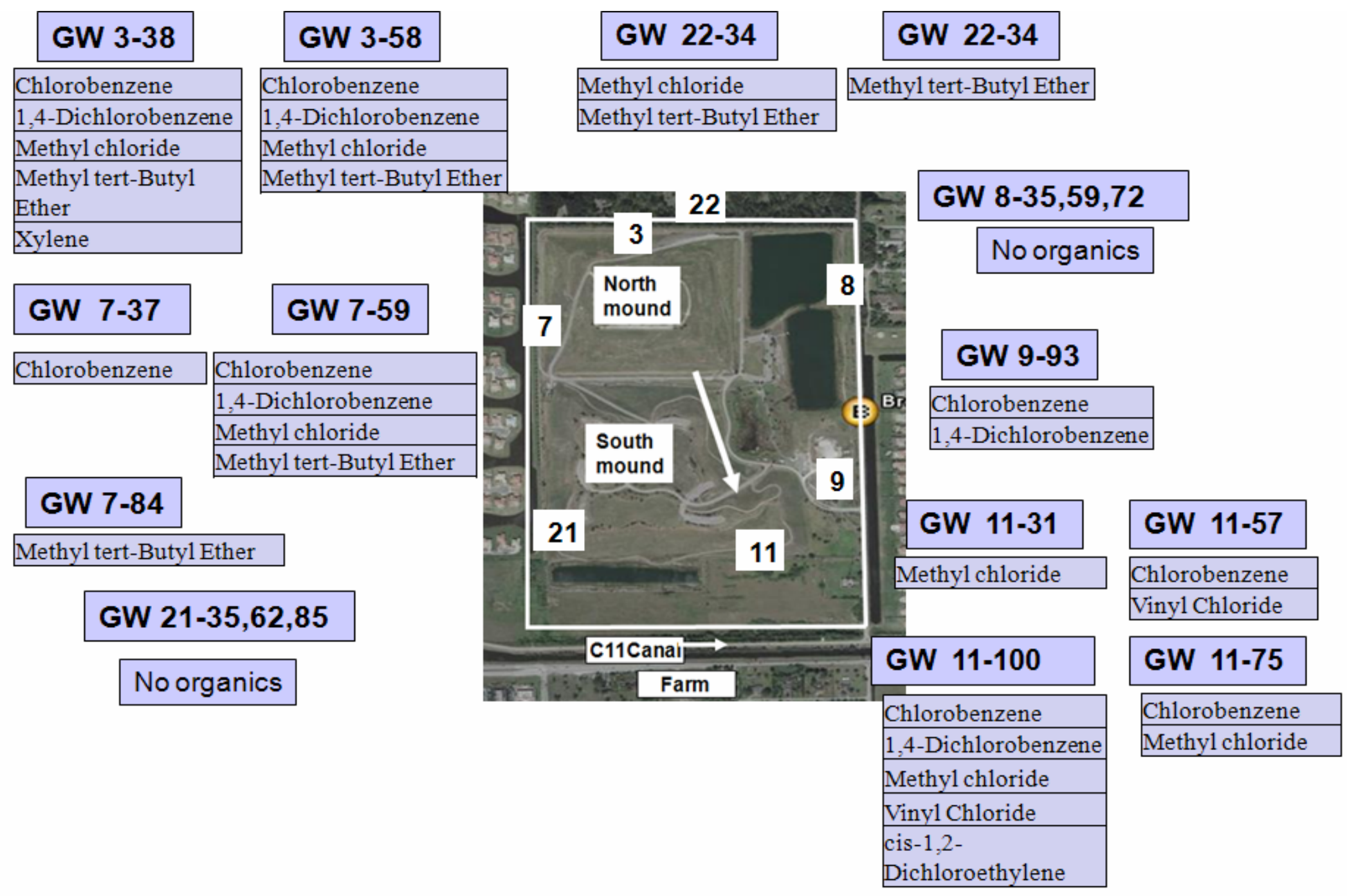

Figure 37. Organic parameters below MCL in GW monitoring wells. 


\subsubsection{Parameters below MCL - Metals}

Detected metal concentrations never exceeded the MCL. Detected metals for each well are shown in Figure 39. Besides the zinc and chromium, also cadmium, chromium, and arsenic were detected as groundwater contaminants.

Chromium: Chromium was detected only in MW 3 and 11. MW 3 is located up gradient

of MW 11. Any contaminants detected in MW 3 have also been detected in MW 11, because of the southeasterly groundwater flow.

Zinc: Figure 40 presents the zinc levels in the monitoring wells. Measured zinc concentration is between BDL and $60 \mu \mathrm{g} / \mathrm{L}$ in all wells. During the 2001- 2003 period zinc levels were fluctuating. However, during the last three years, zinc concentrations have shown a steady trend.

Arsenic: Arsenic was detected in MW 21 and 11. It was detected only last two years. When spoken to manager, it was learnt that detection limit of the measuring device was changed. It was calibrated to very low detection limits.

Cadmium: Cadmium was detected in MW 11. It was detected only last year. When spoken to manager, it was learnt that detection limit of the measuring device for cadmium was changed too. It was calibrated to very low detection limits as arsenic. The concentration is already below MCL and less than $1 \mu \mathrm{g} / \mathrm{L}$

Since zinc, arsenic, chromium and cadmium have never been measured in leachate, the source of these metals could not be identified. 


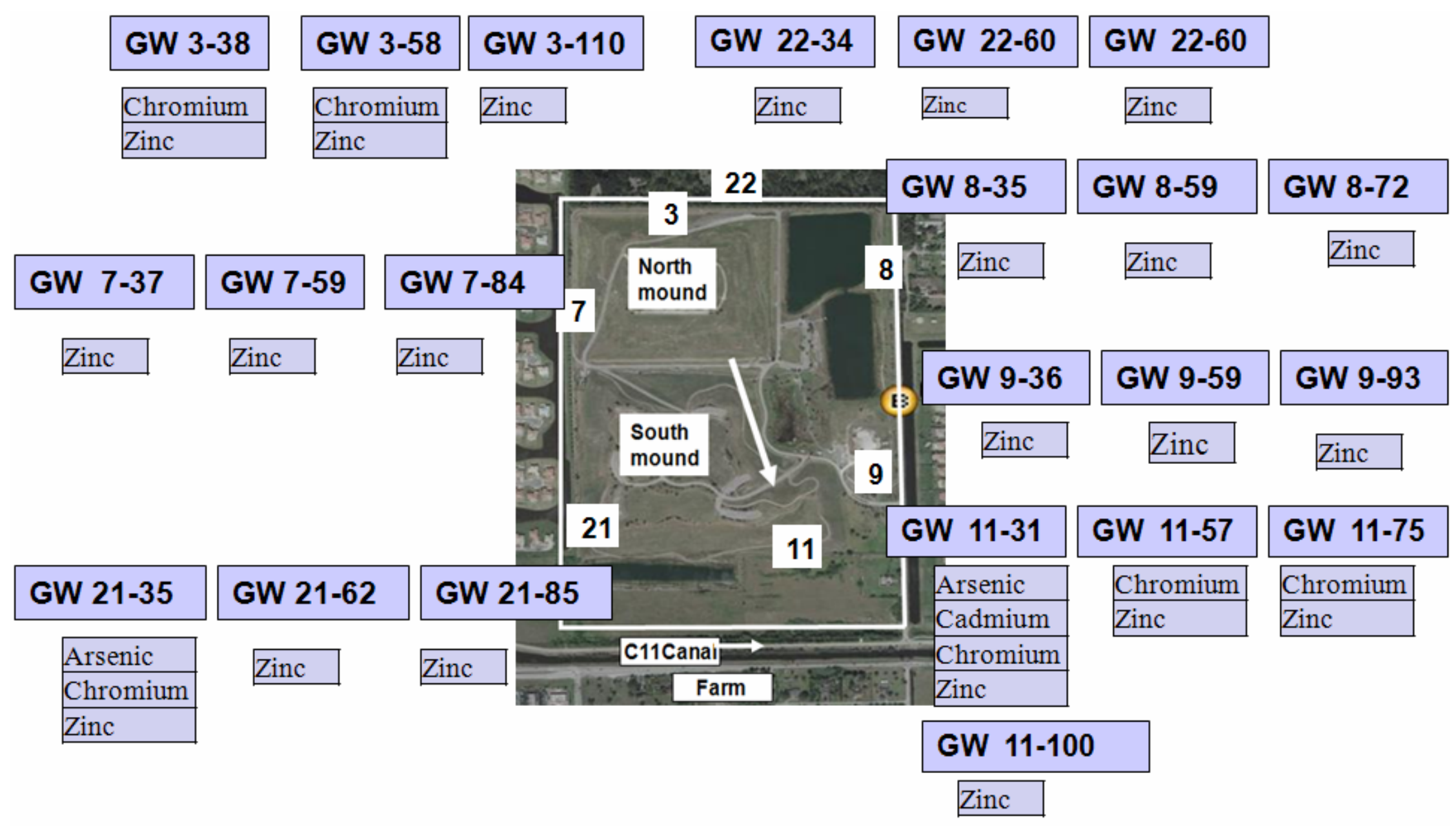

Figure 39. Metallic parameters below MCL in GW monitoring wells. 


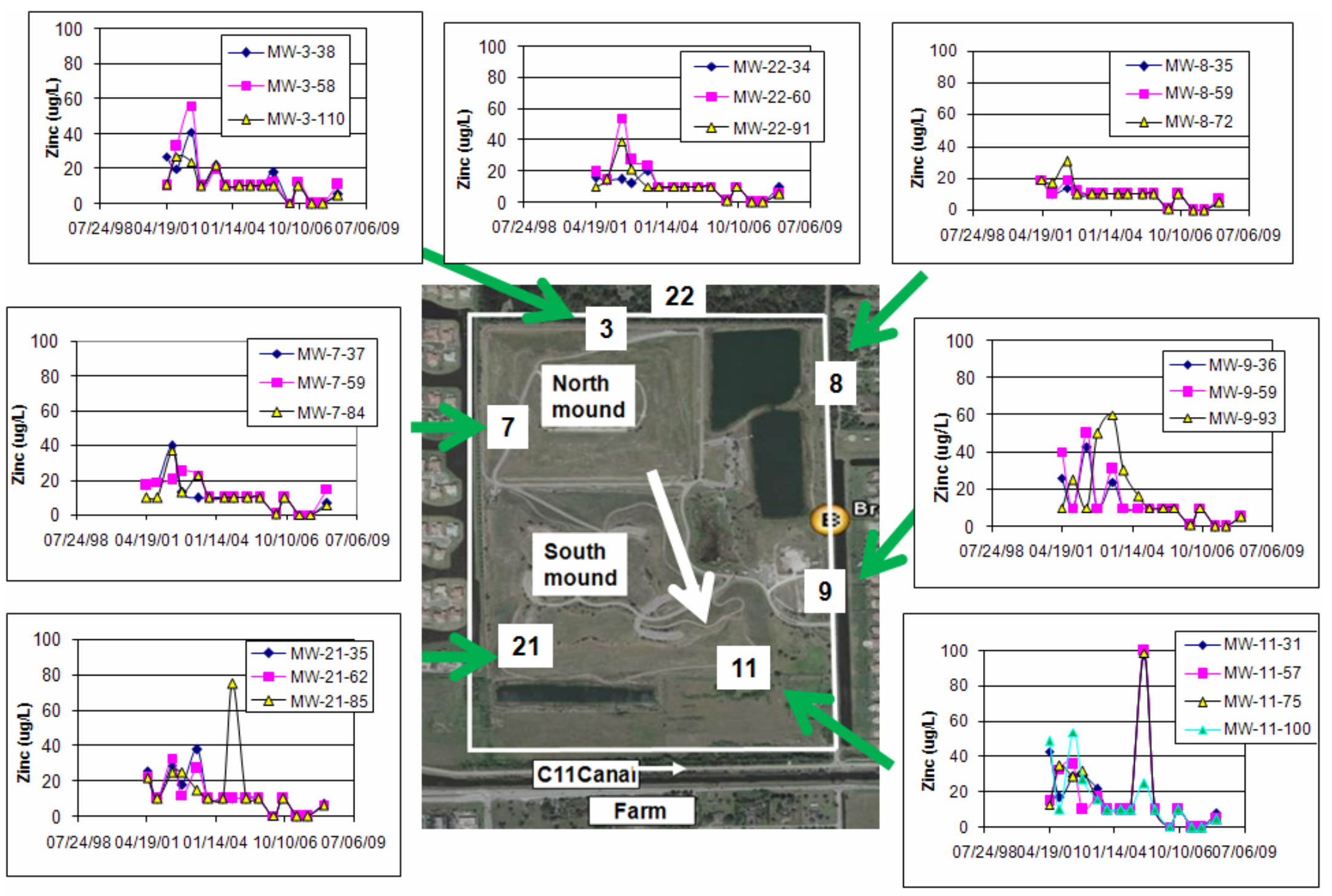

Figure 40. Zinc concentration in all GW monitoring wells. 


\subsection{Cap Module}

The purpose of the cap module is to determine whether the landfill cap is efficient or not and if it can be modified. The function of the cap is to limit infiltration of water and to prevent escape of landfill gas from the landfill surface. The evaluations performed with the cap module were based on the outcomes of the assessments of the leachate module, landfill gas module and landfill settlement. The cap module was used for the following assessments:

1. To identify any correlations between leachate and rainfall,

2. To analyze LFG module outcomes to detect any gas migration, and

3. To evaluate cover material efficiency and the extent and rate of post closure settlement and the stresses that settlement imposes on the integrity of the containment system components.

As a result, the objectives of the cap module are the following:

1. Assess the cap monitoring and maintenance program to decide whether the cap system meets the performance requirements, and

2. Evaluate whether it is feasible to install an alternate cap which is more efficient, require less maintenance, and meets the post closure needs.

RCRA Subtitle D requirements apply to municipal solid waste landfills (MSWL) to be closed using engineered covers and are designed with the intent to meet the following performance expectations:

1. Cover permeability with less than or equal to the permeability of the bottom liner/subsoil or no greater than $10^{-5} \mathrm{~cm} / \mathrm{sec}$,

2. Minimize infiltration using no less than $45 \mathrm{~cm}$ of soil, and 
3. Minimize erosion using no less than $15 \mathrm{~cm}$ of topsoil for plant growth (http://www.sandia.gov/caps/designs.htm).

The Davie Landfill cover system consists of a two-foot thick limerock cover, which is compacted (in six-inch layers) with six inches of vegetative cover soil as shown in Figure 41. Two lifts of material (1-foot thick) was spread and compacted. The final cover was sloped at a $2 \%$ grade towards the southwest corner of the sanitary landfill slopes on the cover are relatively flat on the crown of the landfill cells, with slopes generally 1 to $3 \%$, with some areas that do not readily drain due to settlement.

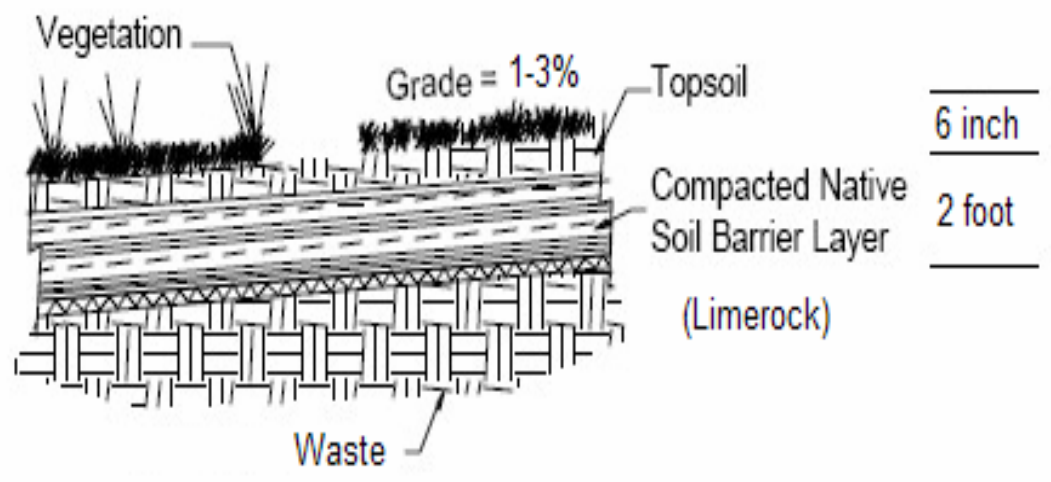

Figure 41. Davie Landfill cover system (adapted from Alternative Landfill Cover Designs Considered in ALCD).

\subsubsection{Leachate Module Outcomes}

During the analyses of leachate data, it was observed that leachate production rates over the years showed significant changes in the quantities immediately after the land use practice of the closed landfill changed in 2003 as shown in Figure 42. When the leachate quantity and rainfall data were compared, it was seen that there is some correlation based on the peaks observed in leachate quantity and rainfall as shown in Figure 43. This indicates that the cap system cannot prevent the infiltration of 
precipitation to the landfill cells. The monitoring data should be evaluated in view of the land use and regrading activities that took place over the years.

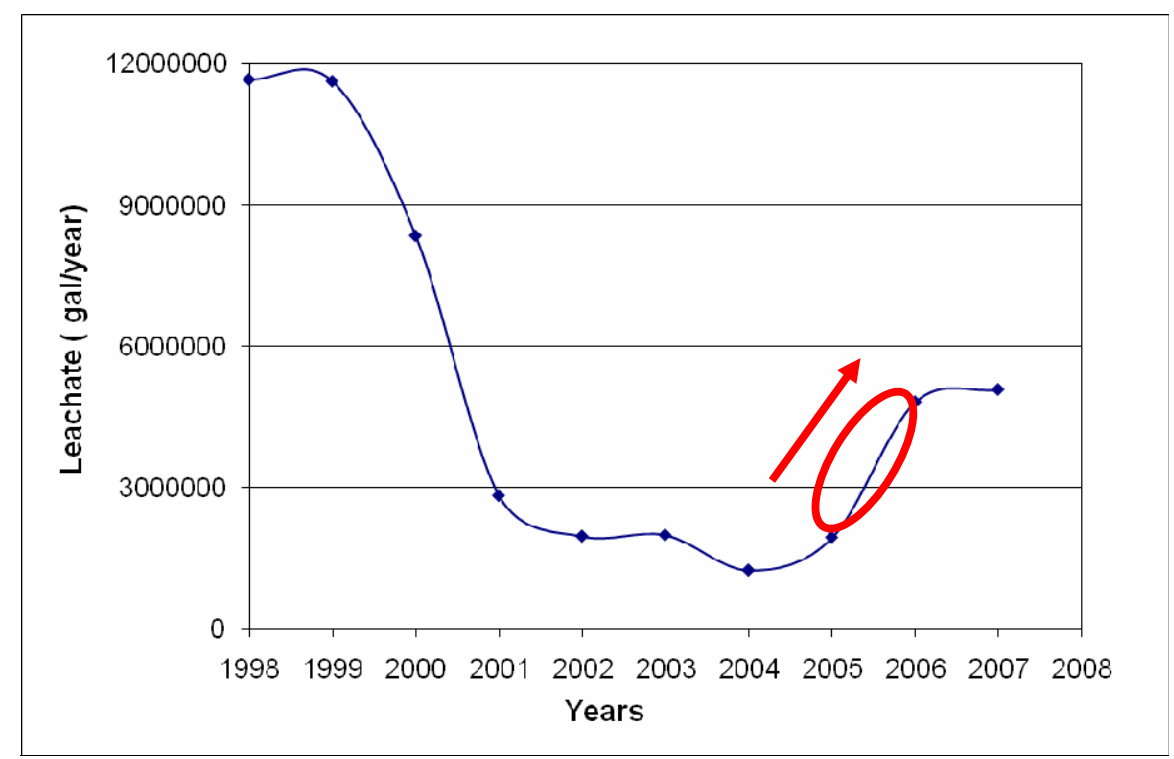

Figure 42. Leachate quantity changes after capping.

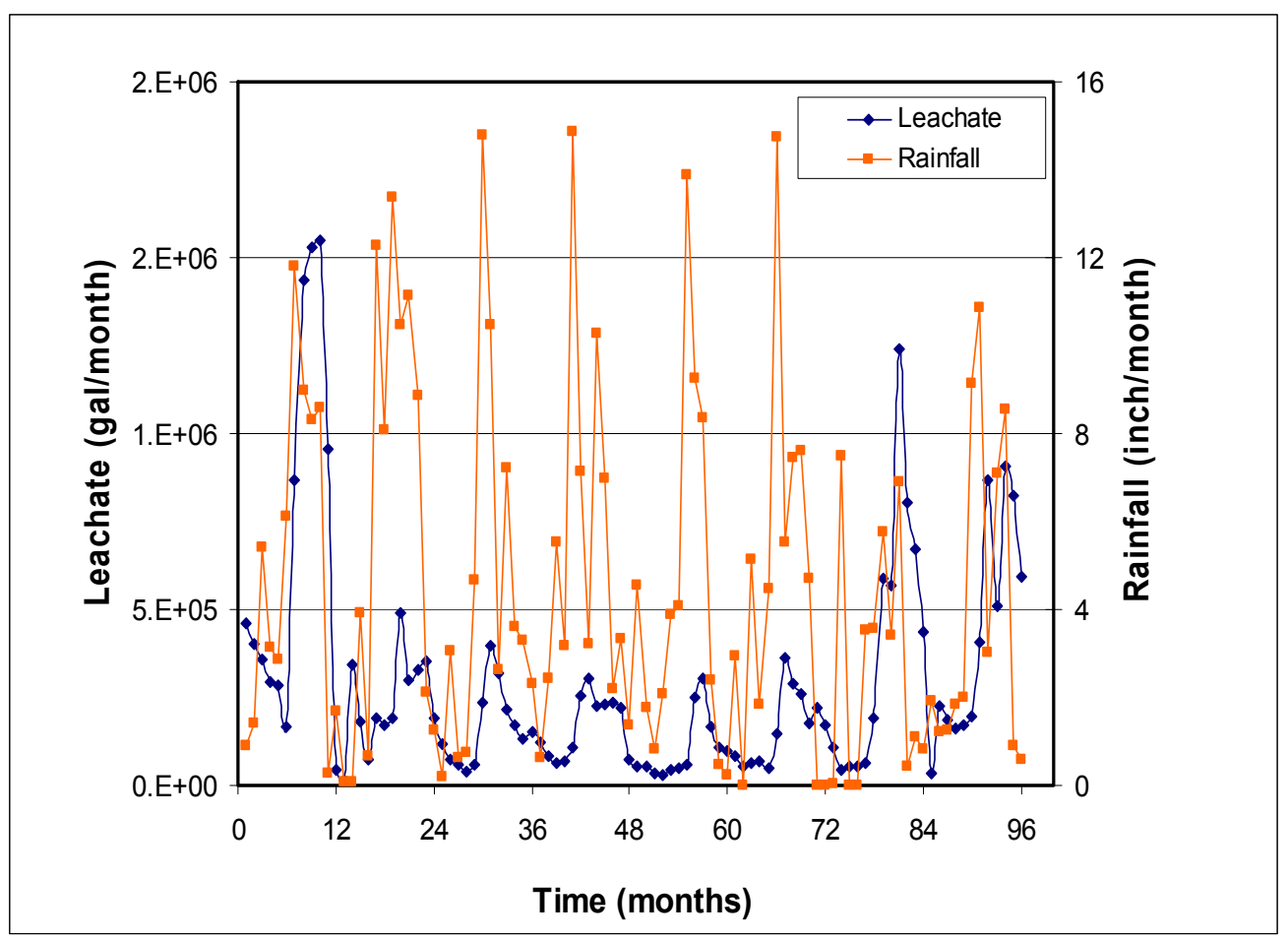

Figure 43. Monthly total leachate vs. monthly total rainfall correlation for assessing cap. 


\subsubsection{Landfill Gas module Outcomes}

Landfill gas module outcome showed us that the landfill cap is not efficient to prevent LFG migration. The calculated LFG from landfill is based on flared gas data. The measured LFG is less than expected based on literature review. Poor capping is the most significant reason for under calculation. According to US EPA's "Compilation of air pollution emission factors, Report AP-42", (USEPA, 1995), researchers and practitioners estimated collection efficiencies to typically range from 60 to $85 \%$. Therefore limestone efficiency to hold LFG should be calculated to find realistic values.

\subsubsection{Cover Material Efficiency and Settlement}

As rain falls through the atmosphere, it absorbs carbon dioxide and forms a weak carbonic acid and when it moves through the cover system, it reacts with living and decaying plant matter and becomes more acidic. The acidic water slowly dissolves the limestone cap and this chemical erosion eventually causes voids or cavities onto limestone cover (www.swfwmd.state.fl.us/hydrology/sinkholes/brochure.pdf). The end result of chemical erosion of limestone, followed by physical collapse or subsidence. Landfills have settled uniformly approximately five feet since 1987. 


\section{CHAPTER 6}

\section{RISK ANALYSIS}

The 30 year PCC period can be shortened or extended depending on whether the landfill presents potential threats to human health or the environment or not (Tansel et al., 2007). The USEPA has concluded that all landfills eventually will leak (USEPA, 1988). Therefore risk assessment is required as a tool to identify and define landfill hazards for the environment (Butta et al., 2003). The most important part of the risk assessment is evaluation of the connectivity between the source of a hazard (landfill) and an environmental receptors ( groundwater, surface water, air, etc.,) (Vose, 2000). In recent years, the USEPA has been applying probabilistic risk assessment approach to quantify modeling uncertainties (Garrick, 2002). Over the last two decades, some models have been developed to understand and predict environmental phenomena, including fluidflow patterns (e.g., groundwater, surface water, and air), contaminant migration and fate, human or wildlife exposures etc (Whelan et al., 1997). Environmental risk tools are based on models that characterize pollutant pathways in environmental systems and model the release of the source of a hazard to the environment (Pollard et al., 2006). Advanced computer programming languages and software tools are capable of producing solutions to risk assessment models, including environmental and public health risks and associated engineering problems (Koliopoulos et al., 2007). In the literature, holistic methodology is limited for landfill leachates to perform risk assessments (Butta et al., 2008). After reviewing risk assessment models such as The Multimedia, Multi-pathway, Multireceptor Exposure and Risk Assessment (3MRA), Hydro-geological Evaluation of Landfill Performance (HELP) and Framework for Risk Analysis Multimedia 
Environmental Systems (FRAMES), FRAMES was selected as the method for analysis of risks resulting from a closed landfill. Ho et al., (2007) used FRAMES models to evaluate the fate and transport of contaminants of concern for mixed waste. Ho et al., (2004) also used this model to evaluate the long-term performance of covers at contaminated sites at the Monticello Mill Tailing Site in Utah. FRAMES is a software platform developed by the Pacific Northwest National Laboratory (PNNL) for selecting and implementing environmental software models for risk assessment and management problems. FRAMES works with Multimedia Environmental Pollutant Assessment System (MEPAS) modules which integrates transport and exposure pathways for chemical releases to determine their potential impact on the environment, individuals, and populations (http://mepas.pnl.gov/mepas/index.stm).

The purpose of this chapter is to analyze the migration pathways and to estimate health risks resulting from closed landfill. While examining the risk, sensitivity analysis was also performed to determine how different values of variables such as Darcy velocity, thickness of soil, contaminant mass in aquifer and different soil types would impact the risk results. Development and incorporation of a risk assessment module during the PCC period will allow more efficient management strategies for closed landfill sites.

\subsection{Health Effects of Contaminants of Concern Detected in Groundwater}

Vinyl Chloride: Vinyl chloride is a product of anaerobic degradation of chlorination solvents such as would be expected to occur in groundwater and landfills (USEPA, 1995a). Vinyl chloride can migrate to groundwater. The EPA and National Toxicology 
Program (NTP) consider vinyl chloride to be a known human carcinogen (ATSDR 2006). Toxicity characteristics of vinyl chloride are shown in Table 20. Vinyl chloride degradation in groundwater could vary between 3 to 5 months depending on the conditions (Davis, 1990; http://www.isocinfo.com/). Based on the literature review, the half life for vinyl chloride was assumed to be 150 days for this study

Table 20. Toxicity characteristics of vinyl chloride

\begin{tabular}{|l|l|}
\hline Acute toxicity & $\begin{array}{l}\text { Occupational inhalation exposure to high levels (e.g., } 40 \text { - 900 ppm ) } \\
\text { may cause neurological effects such dizziness, headaches, or narcosis } \\
\text { in workers (USEPA, 1995a). }\end{array}$ \\
\hline Chronic toxicity & $\begin{array}{l}\text { Oral ingestion at high levels }(0.1 \mathrm{mg} / \mathrm{L} \text { ) may cause liver effects from } \\
\text { life-time exposure (USEPA, 1995a). }\end{array}$ \\
\hline Cancer risk & $\begin{array}{l}\text { Based on epidemiological and animal studies, vinyl chloride is } \\
\text { carcinogenic in humans when inhaled, and it is considered to be a } \\
\text { human carcinogen from oral exposure (USEPA, 1995a). }\end{array}$ \\
\hline
\end{tabular}

Cadmium: Cadmium has the potential to cause kidney, liver, bone and blood damage from long- term exposure at levels above the MCL. (http://www.epa.govsafewater/dwh/tioc/cadmium.html)

Xylenes: Xylenes above the MCL cause disturbances in the central nervous system, such as changes in cognitive abilities, balance, and coordination as an acute effect. Xylenes cause damage to the central nervous system, liver and kidneys from long-term exposures at levels above the MCL.

Chromium: Chromium above MCL causes skin irritation or ulceration from acute exposure. Chromium causes damage to liver, kidney circulatory and nerve tissues; dermatitis from long-term exposures at levels above the MCL. (EPA)

Chlorobenzene: Chlorobenzene above MCL causes anesthetic effects and impaired liver and kidney function from acute exposure. Chlorobenzene has the potential to cause liver, 
kidney and central nervous system damage from long-term exposure at levels above the MCL. (EPA) http://www.epa.gov/chemfact/chlor-fs.pdf

1,2-Dichloroethene: Lower oral doses of cis-1,2-dichloroethene affect blood chemistry, such as decreased numbers of red blood cells, and the liver. http://www.atsdr.cdc.gov/toxprofiles/tp87-c1.pdf

1,4-Dichlorobenzene: Acute exposure to 1,4-dichlorobenzene via inhalation in humans results in irritation to the eyes, skin, and throat. Chronic exposure to 1,4-dichlorobenzene by inhalation in humans results in effects on the liver, skin, and CNS (e.g., cerebellar ataxia, dysarthria, weakness in limbs, and hyporeflexia). (http://www.epa.gov/ttn/atw/hlthef/dich-ben.html)

Zinc: Zinc causes adverse health effects such as loss of appetite, decreased sense of taste and smell, lowered ability to fight off infections, slow growth, slow wound-healing and skin sores. Eating or drinking too much zinc in a short period of time can lead to adverse health effects, such as stomach cramps, nausea and vomiting. There is no evidence that zinc causes cancer in humans ( http://www.idph.state.il.us/envhealth/factsheets/zinc.htm) Arsenic: Exposure Dosage Effect Low Exposure - micrograms 0.1 - $10 \mu \mathrm{g}$. No known human adverse health effects. http://www.nab.usace.army.mil/projects/WashingtonDC/springvalley/arsenic/

Iron: When iron exceeds the required amount, it is stored in the liver. This may damage this vital organ. Water soluble binary iron compounds such as $\mathrm{FeCl}_{2}$ and $\mathrm{FeSO}_{4}$ may cause toxic effects at concentrations exceeding $200 \mathrm{mg}$, and are lethal for adults at doses of 10-50 g. (http://www.lenntech.com/elements-and-water/iron-and-water.htm) 


\subsection{Susceptibility of Landfill}

The landfill is $525 \mathrm{~m}$ in length and $405 \mathrm{~m}$ in width. The sub soil is sand, and depth to groundwater is $1.5 \mathrm{~m}$. The landfill is shown in Figure 44 with the receptors. The leachate collection system from the sanitary landfill drains into a main sump, where it is pumped to wastewater treatment plant (US Corp of Engineers 2005; 2000; USEPA 1995b).

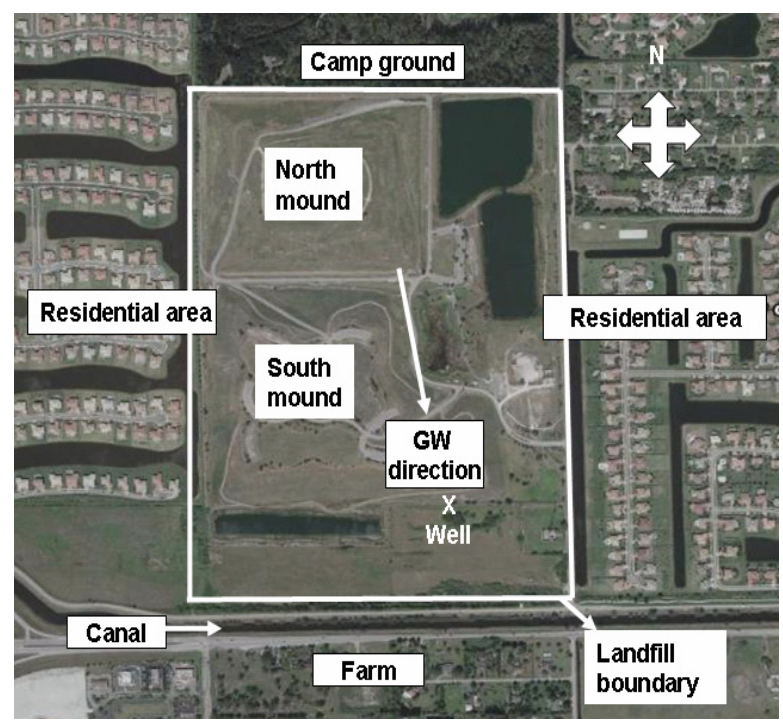

Figure 44. Landfill receptors (Google earth)

\subsection{Methodology}

FRAMES was chosen as the risk assessment tool for the case study landfill. This model takes a holistic approach to environmental assessment of potential contaminant impacts as it simulates 1) the release of contaminants into the environment, 2) migration and fate through various environmental media (i.e., groundwater, surface water, air, and overland surfaces), and 3) resultant exposures and impacts. FRAMES aids the user in constructing a Conceptual Site Model a site that is reconstructed on screen by choosing icons that represent the real or potential flow of contamination. FRAMES' modularization produces several types of time-varying outputs including the following: 
- Constituent mass remaining at source

- Constituent fluxes from source or medium

- Soil deposition

- Water concentrations

- Intake or dose

- Hazard quotient or risk.

FRAMES works with Multimedia Environmental Pollutant Assessment System (MEPAS). MEPAS is developed by Pacific Northwest National Laboratory (PNNL) to assess contaminated environmental problems. MEPAS simulates the release of contaminants from a source; transport through the air, groundwater, surface water, and/or overland pathways; and transfer through food chains and exposure pathways to the exposed individual or population. For human health impacts, risks are computed for carcinogens and hazard quotients for noncarcinogens.

MEPAS 5.0 Source in Aquifer, Exposure pathways, Receptor intakes and Health Impacts modules are chosen for this study shown in Figure 45.

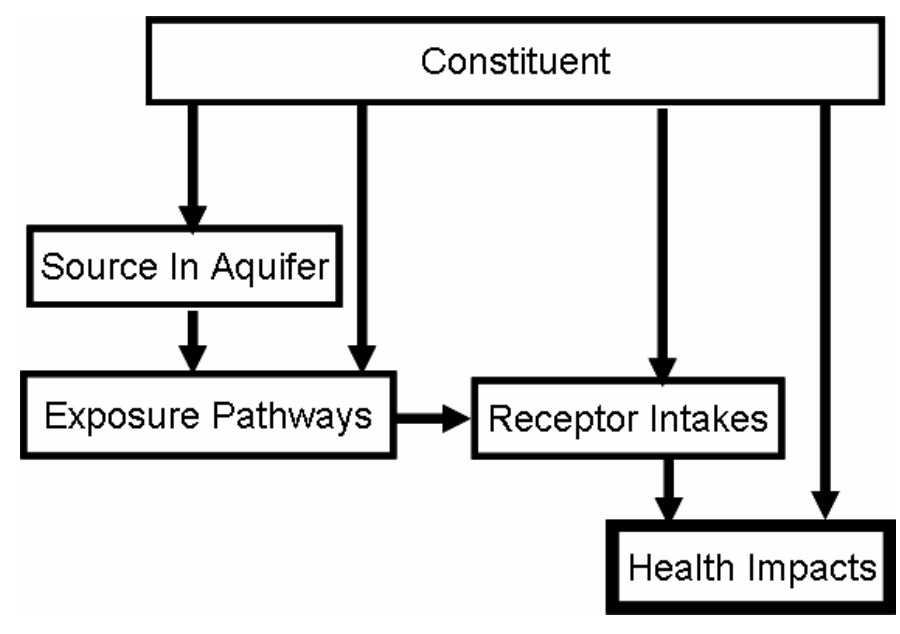

Figure 45. Selected FRAMES modules for case study landfill. 


\subsubsection{Source Term Module}

The MEPAS Computed Source Term Release Module (CSTRM) is based on constantly stirred tank reactor (CSTR) model that assumes that the contamination is instantly distributed homogeneously throughout the defined source volume. The CSTRM assumes that the contaminants may be present in multiple phases (i.e., in aqueous solution, sorbed to solid particles, in vapor-filled pore space, or in a separate nonaqueous-phase liquid (NAPL) that is immiscible with water and air) (Buck, 2001; Streile 1996). In this study, source is defined in aquifer. Since the source was in aquifer, overland runoff loss, suspension loss, volatilization loss routes were neglected. In the leaching loss route parameter, Darcy velocity was known and it was selected as a value. Other selected parameters for this module are shown in Table 21.

Table 21. Selected parameters for Source in Aquifer Models (Tansel et al., 2008)

\begin{tabular}{|l|l|l|}
\hline \multicolumn{1}{|c|}{ Parameter } & \multicolumn{1}{c|}{ Value } & \multicolumn{1}{c|}{ Units } \\
\hline Time interval for simulation & 1 & years \\
\hline Time period for simulation & 10 & years \\
\hline Residual mass for simulation & 0.01 & fraction \\
\hline Thickness of clean overburden & 0.0 & $\mathrm{~m}$ \\
\hline Thickness & 1.5 & $\mathrm{~m}$ \\
\hline Length & 533 & $\mathrm{~m}$ \\
\hline Width & 411 & $\mathrm{~m}$ \\
\hline Bulk density & 1.64 & $\mathrm{~g} / \mathrm{cm}^{3}$ \\
\hline Total porosity & 38 & $\%$ \\
\hline Effective porosity & 25 & $\%$ \\
\hline Average air temperature & 23.27 & ${ }^{0} \mathrm{C}$ \\
\hline Vinyl chloride water solubility & 2670 & $\mathrm{mg} / \mathrm{L}$ \\
\hline $\begin{array}{l}\text { Vinyl chloride concentration in GW (mass } \\
\text { aqueous constituent/volume water) }\end{array}$ & $2.15 \mathrm{E}-03 *$ & $\mathrm{mg} / \mathrm{L}$ \\
\hline Vinyl chloride decay/degradation half life in GW & 150 & $\mathrm{day}$ \\
\hline Vinyl chloride Kd's (Estimated Value) & 0.048222 & $\mathrm{ml} / \mathrm{g}$ \\
\hline Darcy velocity of media & 0.043 & $\mathrm{~cm} / \mathrm{day}$ \\
\hline
\end{tabular}

* 2004 data vinyl chloride data was taken an example to show the entered data 


\subsubsection{Exposure Pathways Module}

The MEPAS Exposure Pathways Module was used to calculate pollutant concentrations in exposure media resulting from contamination of groundwater. The module includes consideration of domestic water use, farm product consumption, aquatic food consumption, surface water recreational activities, soil contact exposure, and air exposures. In this study only domestic water use, plant product use and inhalation via volatilization from water were considered. EPA indoor air model was used for evaluation of indoor air inhalation of volatile compounds. Transfer of activity through food chains model uses concentration ratios, bioaccumulation factors and transfer factors. For waterborne contamination, exposure media concentrations are evaluated for one location (Strenge, 2001a; Strenge 1995).

\subsubsection{Receptor Intakes Module}

The MEPAS Receptor Intakes Module evaluates the intake or exposure of an individual from consumption or contact with contaminated media. Standard EPA methods were used to evaluate the average daily intake rate of chemical pollutants for each exposure pathway, based on user defined consumption/contact rates and body weight such as average body weight determined $70 \mathrm{~kg} /$ person and groundwater and surface water ingestion rate were determined $1.4 \mathrm{~L} /$ day. EPA models were used to evaluate dermal contact with water. The module evaluates intakes for one age group per receptor definition and for all input exposure routes defined in the EPF file and recognized by MEPAS (Strenge, 2001b). 


\subsubsection{Health Impacts Module}

The MEPAS Health Impacts Module calculates health impacts from intake or exposure to chemicals. Chemical impacts were evaluated for inhalation, ingestion, and dermal contact pathways as either cancer incidence or hazard index, as appropriate for the chemical of concern (Strenge, 2001c). Figure 46 shows used pathways and routes for risk calculation of contaminated groundwater under case study landfill.

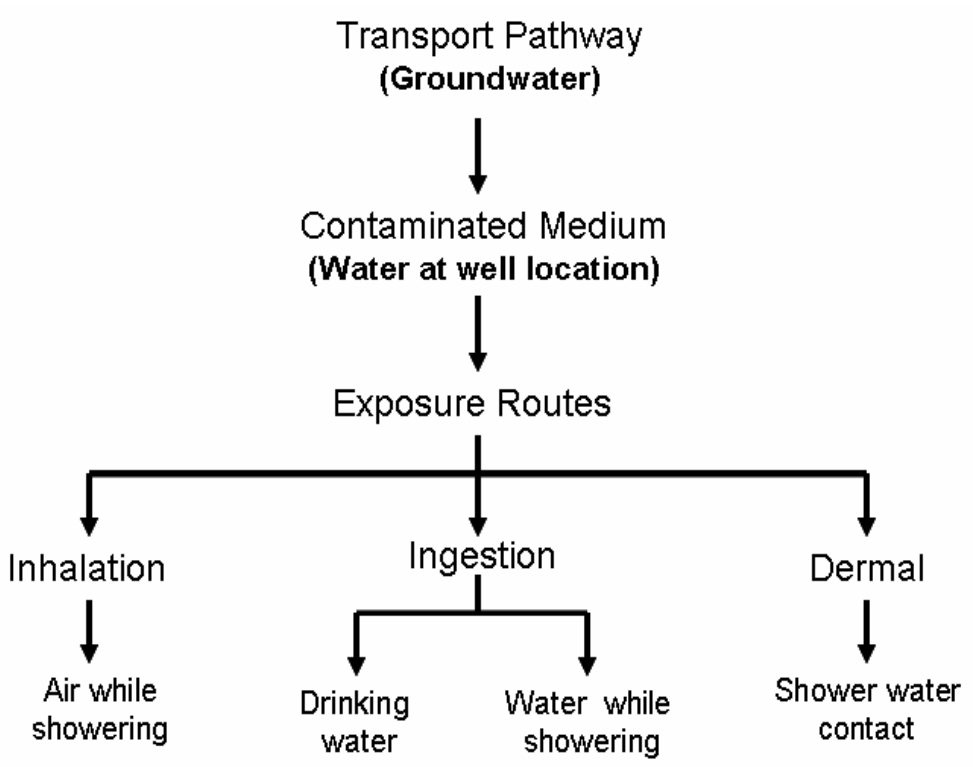

Figure 46. Exposure Pathways.

\subsubsection{Estimation of exposure levels}

The exposure pathway analysis starts with vinyl chloride concentration in groundwater and estimates the average daily dose to exposed individuals from contact with drinking water, shower and consumption of plants produced around the landfill area. The average daily dose is used to estimate of health impact. The average daily dose of a pollutant for an exposure pathway involves consideration of the rate of intake (ingestion, dermal absorption and inhalation), the frequency of exposure, the exposure duration, the 
averaging time, and the body weight of individual. All those exposure formulas were taken from Strenge, 1995.

\subsection{Risk Assessment Results}

The migration pathway and estimation of health risks resulting from landfill to residents living around the landfill area was analyzed in this chapter. The human health impact and risk assessment started with vinyl chloride intake from an exposure medium and pathways. Human health risk was evaluated in terms of cancer and non cancer effects for exposure to vinyl chloride, chlorobenzene, 1,4 dichlorobenzene, chromium, cadmium, iron, zinc, arsenic, ammonia as nitrogen, and xylene. The groundwater was assumed to be untreated and would not be used as a drinking water source but used for irrigation purposes for open lands neighboring the landfill area. Total human health risk was evaluated in terms of cancer and non cancer effects for exposure to selected contaminants as summarized in Table 22.

Table 22. Selected GW parameters.

\begin{tabular}{|c|c|}
\hline Contaminants & Concentration (2008) \\
\hline 1,2 dichlorethane & $1.2 \mathrm{ug} / \mathrm{L}$ \\
\hline 1,4 Dichlorobenzene & $3.4 \mathrm{ug} / \mathrm{L}$ \\
\hline Iron & $4360 \mathrm{ug} / \mathrm{L}$ \\
\hline Ammonia & $59.8 \mathrm{mg} / \mathrm{L}$ \\
\hline Arsenic & $4.69 \mathrm{ug} / \mathrm{L}$ \\
\hline Cadmium & $0.45 \mathrm{ug} / \mathrm{L}$ \\
\hline Chromium & $1.72 \mathrm{ug} / \mathrm{L}$ \\
\hline Zinc & $15 \mathrm{ug} / \mathrm{L}$ \\
\hline Chlorobenzene & $10.5 \mathrm{ug} / \mathrm{L}$ \\
\hline Vinyl Chloride & $2.1 \mathrm{ug} / \mathrm{L}$ \\
\hline Xylene & $1.1 \mathrm{ug} / \mathrm{L}$ \\
\hline
\end{tabular}


The lifetime risk of total cancer incidence is estimated using EPA slope factors for chemical carcinogens for inhalation, ingestion and dermal pathways. The EPA slope factors give the lifetime cancer incidence risk per average daily dose. Incremental cancer risks were estimated as a probability, or chance, that a person would develop cancer over his or her lifetime as a result of exposure to the vinyl chloride from landfill. The risk of "one in one million" means that if one million people were exposed to the vinyl chloride around the landfill site for 10 years, at most one case of cancer would be expected to occur over lifetime as a result of their exposure. Non cancer hazard potential (hazard index, HI) is presented as a ratio of the predicted exposure compared to a safe level (reference dose). The reference dose represents a level that is believed to be safe for members of the general population. Exposure at this level will result in a hazard index of 1.0. Exposures yielding an $\mathrm{HI}$ less than 1.0 may not result in adverse non cancer health effects and an HI value greater than 1.0 may not suggest a likelihood of adverse effects. The HI cannot be translated to a probability that adverse effects will occur and is not likely to be proportional to risk. A respiratory $\mathrm{HI}$ greater than 1.0 indicates that a potential may exist for adverse irritation to the respiratory system (Strenge et al., 1995).

The non carcinogenic and carcinogenic risks were estimated according to the dermal, inhalation, and ingestion exposures routes using 2008 groundwater monitoring data. Total risk was calculated for concerned metals and volatile organic compounds (VOCs) determined in groundwater monitoring wells. The total risk resulted from VOCs has significant value $\left(2.2 \times 10^{-6}\right)$ shown in Table 23 . 
Table 23. Risk calculation for vinyl chloride, chlorobenzene, 1,4 dichlorobenzene, xylene.

\begin{tabular}{|c|c|c|}
\hline $\begin{array}{l}\text { All Chemicals summation } \\
\text { for Aquifer }\end{array}$ & HI Non carcinogenic * & Risk Carcinogenic \\
\hline ingestion (total) & $1.18 \mathrm{E}-03$ & $1.53 \mathrm{E}-06$ \\
\hline$\bullet \quad$ Leafy vegetables & $1.58 \mathrm{E}-04$ & $1.67 \mathrm{E}-07$ \\
\hline$\bullet \quad$ Other vegetables & $3.07 \mathrm{E}-05$ & $2.46 \mathrm{E}-08$ \\
\hline$\bullet \quad$ Shower & $7.08 \mathrm{E}-06$ & $9.50 \mathrm{E}-09$ \\
\hline$\bullet \quad$ Water & $9.87 \mathrm{E}-04$ & $1.32 \mathrm{E}-06$ \\
\hline Inhalation (shower) & $1.04 \mathrm{E}-02$ & $6.24 \mathrm{E}-07$ \\
\hline Dermal (Shower) & $8.19 \mathrm{E}-05$ & $5.28 \mathrm{E}-08$ \\
\hline TOTAL & $1.17 \mathrm{E}-02$ & $2.20 \mathrm{E}-06$ \\
\hline
\end{tabular}

Hazard Index value for VOC's is less than 1. Since the VOCs in groundwater have steady trend, the monitoring should be continued. Total risk resulted from metals in groundwater is less than EPA's standard as shown in Table 24 (less than $10^{-6}$ ), since the concentration of metals detected in groundwater are below MCL. The risk analysis results showed that, metals and volatile organic compounds detected in the groundwater are not harmful to the residents living around the Davie Landfill. Since VOC's detected in GW have steady trend, VOCs should be continued to monitor in groundwater monitoring wells, and monitoring frequency of metals can be reduced.

Table 24. Risk calculation for, arsenic, ammonia as Nitrogen, cadmium, chromium, iron, zinc .

\begin{tabular}{|c|c|c|}
\hline $\begin{array}{l}\text { All Chemicals summation } \\
\text { for Aquifer }\end{array}$ & HI Non carcinogenic * & Risk Carcinogenic \\
\hline ingestion (total) & 2.543 & $3.177-07$ \\
\hline$\bullet \quad$ Leafy vegetables & $3.55 \mathrm{E}-01$ & $1.88 \mathrm{E}-07$ \\
\hline$\bullet \quad$ Other vegetables & $3.92 \mathrm{E}-02$ & $1.49 \mathrm{E}-08$ \\
\hline$\bullet \quad$ Shower & $1.52 \mathrm{E}-02$ & $8.13 \mathrm{E}-10$ \\
\hline Water & 2.132 & $1.14 \mathrm{E}-07$ \\
\hline Inhalation (shower) & 2.62 & 0 \\
\hline Dermal (Shower) & $1.15 \mathrm{E}-02$ & 0 \\
\hline TOTAL & 5.17 & $3.19 \mathrm{E}-07$ \\
\hline
\end{tabular}




\subsection{Vinyl Cloride Risk Assessment}

Among the VOCs, vinyl chloride has significant importance due to its consistency in groundwater and its great reverse health effects on human health. Therefore vinyl chloride risk has been assessed separately. Vinyl chloride concentrations over years are shown in Table 25 .

Table 25. Vinyl Chloride concentrations by years.

\begin{tabular}{|c|c|}
\hline Years & $\begin{array}{c}\text { Vinyl Chloride Concentration } \\
(\mu \mathrm{g} / \mathrm{L})\end{array}$ \\
\hline 2004 & 2.15 \\
\hline 2005 & 2.5 \\
\hline 2006 & 2.35 \\
\hline 2007 & 2 \\
\hline 2008 & 1 \\
\hline
\end{tabular}

The non carcinogenic and carcinogenic risks were estimated according to the dermal, inhalation, and ingestion exposures routes using data available from 2004 to 2008 shown in Table 26.

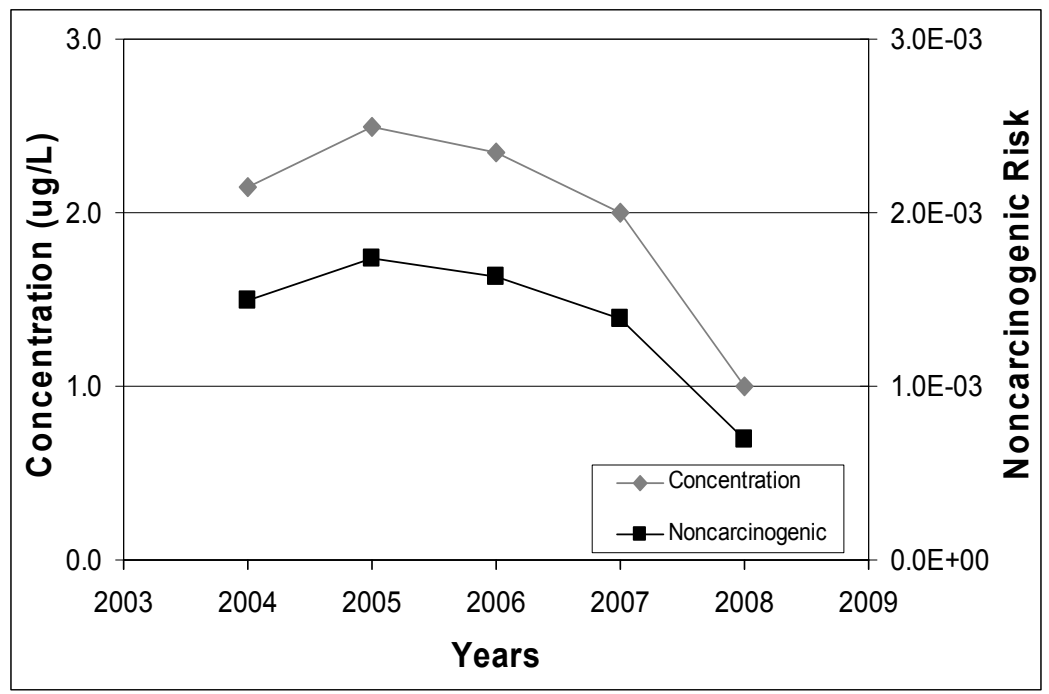

Figure 47. Non Carcinogenic risk vs. concentration by years. 


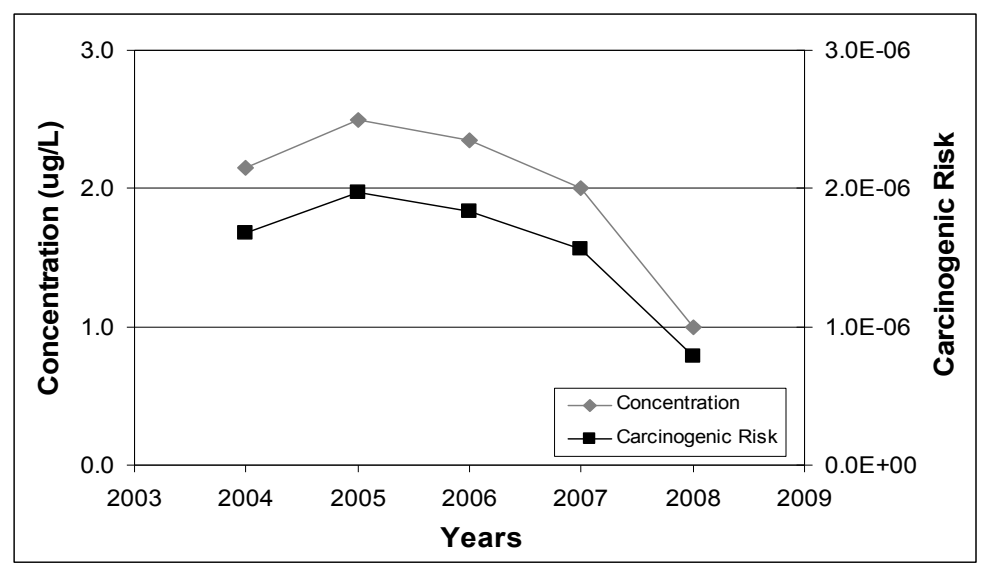

Figure 48. Carcinogenic risk vs. concentration by years.

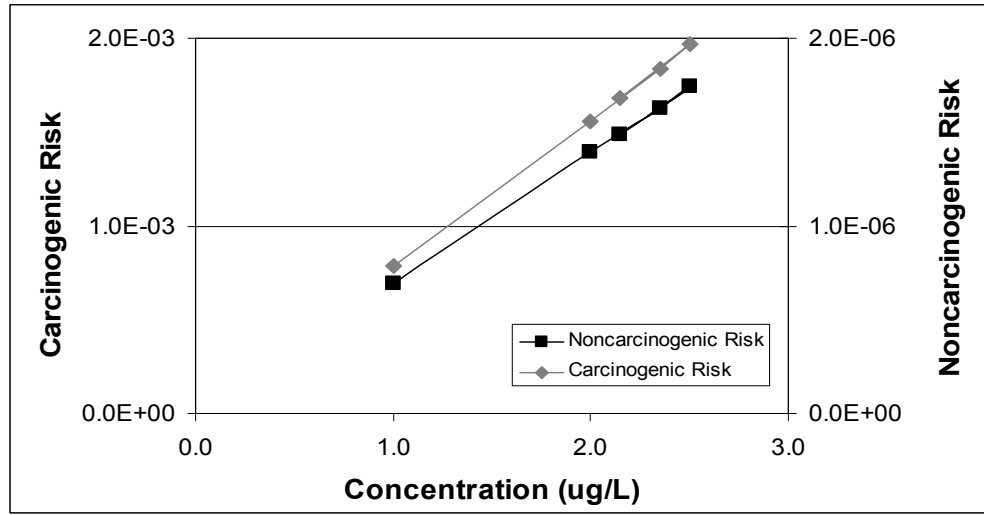

Figure 49. Non Carcinogenic/Carcinogenic risk vs. concentration.

Although all the hazard indices were less than 1, the estimated total cancer risk of exposed to vinyl chloride from landfill via groundwater were higher than USEPA acceptable limit $\left(10^{-6}\right)$. As shown in Figures 47 and 48 both carcinogenic and non carcinogenic risks followed a direct correlation with majored concentration levels for vinyl chloride. The concentration levels in groundwater reached the maximum in 2005 which corresponded to highest risk levels estimated. The observed concentration trends indicate that the carcinogenic risk levels were reduced to acceptable levels by EPA. The estimated risks by FRAMES show linear correlation with concentration as shown in Figure 49. In this case the monitoring should be continued, since the hazard from landfill to residents is still effective. 
Table 26. Risk assessment summaries for vinyl chloride.

\begin{tabular}{|c|c|c|c|c|c|c|c|c|c|c|}
\hline & $\mathbf{2 0 0 4}$ & & $\mathbf{2 0 0 5}$ & & $\mathbf{2 0 0 6}$ & & $\mathbf{2 0 0 7}$ & & $\mathbf{2 0 0 8}$ & \\
\hline Aquifer & HI Non C & Risk C & HI Non C* & Risk C & HI Non C* & Risk C & HI Non C* & Risk C & HI Non C* & Risk C \\
\hline Ingestion (total) & $7.64 \mathrm{E}-04$ & $1.37 \mathrm{E}-06$ & $8.9 \mathrm{E}-04$ & $1.60 \mathrm{E}-06$ & $8.36 \mathrm{E}-04$ & $1.5 \mathrm{E}-06$ & $7.10 \mathrm{E}-04$ & $1.27 \mathrm{E}-06$ & $3.55 \mathrm{E}-04$ & $6.4 \mathrm{E}-07$ \\
\hline $\begin{array}{c}\text { Leafy } \\
\text { Vegetables }\end{array}$ & $4.47 \mathrm{E}-05$ & $8.06 \mathrm{E}-08$ & $5.2 \mathrm{E}-05$ & $9.37 \mathrm{E}-08$ & $4.9 \mathrm{E}-05$ & $8.81 \mathrm{E}-08$ & $4.17 \mathrm{E}-05$ & $7.49 \mathrm{E}-08$ & $2.08 \mathrm{E}-05$ & $3.75 \mathrm{E}-08$ \\
\hline $\begin{array}{c}\text { Other } \\
\text { Vegetables }\end{array}$ & $6.23 \mathrm{E}-06$ & $1.12 \mathrm{E}-08$ & $7.23 \mathrm{E}-06$ & $1.3 \mathrm{E}-08$ & $6.8 \mathrm{E}-06$ & $1.22 \mathrm{E}-08$ & $5.8 \mathrm{E}-06$ & $1.04 \mathrm{E}-08$ & $8.9 \mathrm{E}-07$ & $5.21 \mathrm{E}-09$ \\
\hline $\begin{array}{c}\text { Water } \\
\text { Inhalation } \\
\text { (shower only) }\end{array}$ & $7.13 \mathrm{E}-04$ & $1.28 \mathrm{E}-06$ & $8.3 \mathrm{E}-04$ & $1.5 \mathrm{E}-06$ & $7.8 \mathrm{E}-04$ & $1.4 \mathrm{E}-06$ & $6.63 \mathrm{E}-04$ & $1.19 \mathrm{E}-06$ & $3.03 \mathrm{E}-04$ & $5.98 \mathrm{E}-07$ \\
\hline $\begin{array}{c}\text { Dermal } \\
\text { (shower only) }\end{array}$ & $2.57 \mathrm{E}-05$ & $4.63 \mathrm{E}-08$ & $3 \mathrm{E}-05$ & $5.4 \mathrm{E}-08$ & $2.82 \mathrm{E}-05$ & $5.07 \mathrm{E}-08$ & $2.4 \mathrm{E}-05$ & $4.31 \mathrm{E}-08$ & $1.2 \mathrm{E}-05$ & $7.21 \mathrm{E}-08$ \\
\hline \begin{tabular}{c} 
Total $* *$ \\
\hline
\end{tabular} & $1.52 \mathrm{E}-03$ & $1.68 \mathrm{E}-06$ & $1.74 \mathrm{E}-03$ & $2 \mathrm{E}-06$ & $1.63 \mathrm{E}-03$ & $1.84 \mathrm{E}-06$ & $1.48 \mathrm{E}-03$ & $1.55 \mathrm{E}-06$ & $6.94 \mathrm{E} 04$ & $7.85 \mathrm{E}-07$ \\
\hline
\end{tabular}

* HI: Hazard Index

Non C: Non Carcinogenic

$\mathrm{C}$ : Carcinogenic

** Total $=$ ingestion $($ total $)+$ inhalation $($ total $)+$ dermal $($ total $)$

Risk was calculated based on followings;

Darcy velocity: $0.043 \mathrm{~cm} /$ day

Soil type: Sand

Thickness: $150 \mathrm{~cm}$. 


\subsection{Sensitivity Analysis- Factorial Design}

Factorial analysis allows for the simultaneous study of the effects of several factors on a process. Conducting the study by varying the levels of the factors simultaneously rather than one factor at a time is more efficient in terms of time and cost, and also allows for the study of interactions between the factors. Interactions are the driving force in many processes (Minitab 15 StatGuide; Murphy et al., 1998). The FRAMES software was used to characterize the risks resulting from the landfill using a factorial analysis. A $3 \times 3$ factorial analysis was used to understand the effects of Darcy velocity, thickness of subsoil below the landfill (i.e., depth to groundwater), and amount of contaminant in the aquifer on carcinogenic and noncarcinogenic risks as well as hazard index. The settings of the factorial design parameters are presented in Table 27. In addition, carcinogenic and noncarcinogenic risks (i.e., hazard index) for different soil types were evaluated to compare the results with the base line case (i.e., case study landfill).

Table 27. Factorial Design

\begin{tabular}{|l|c|}
\hline Parameter & Level \\
\hline \multirow{3}{*}{ Darcy Velocity (cm/day) } & 0.004 \\
& 0.003 \\
& 0.600 \\
\hline \multirow{3}{*}{ Thickness (cm) } & 150 \\
& 225 \\
& 300 \\
\hline \multirow{2}{*}{ Mass (g) } & 150 \\
& 400 \\
\hline
\end{tabular}

Based on the factorial design plotted on the graphs, Darcy velocity showed no effect on the risk shown in Figure 50 and 51. The higher concentrations of contaminants 
in aquifer resulted in the higher values of risk shown in Figure 50 and 52. Also the thicker the soil resulted in the lower values of risk shown in Figure 51 and 52.

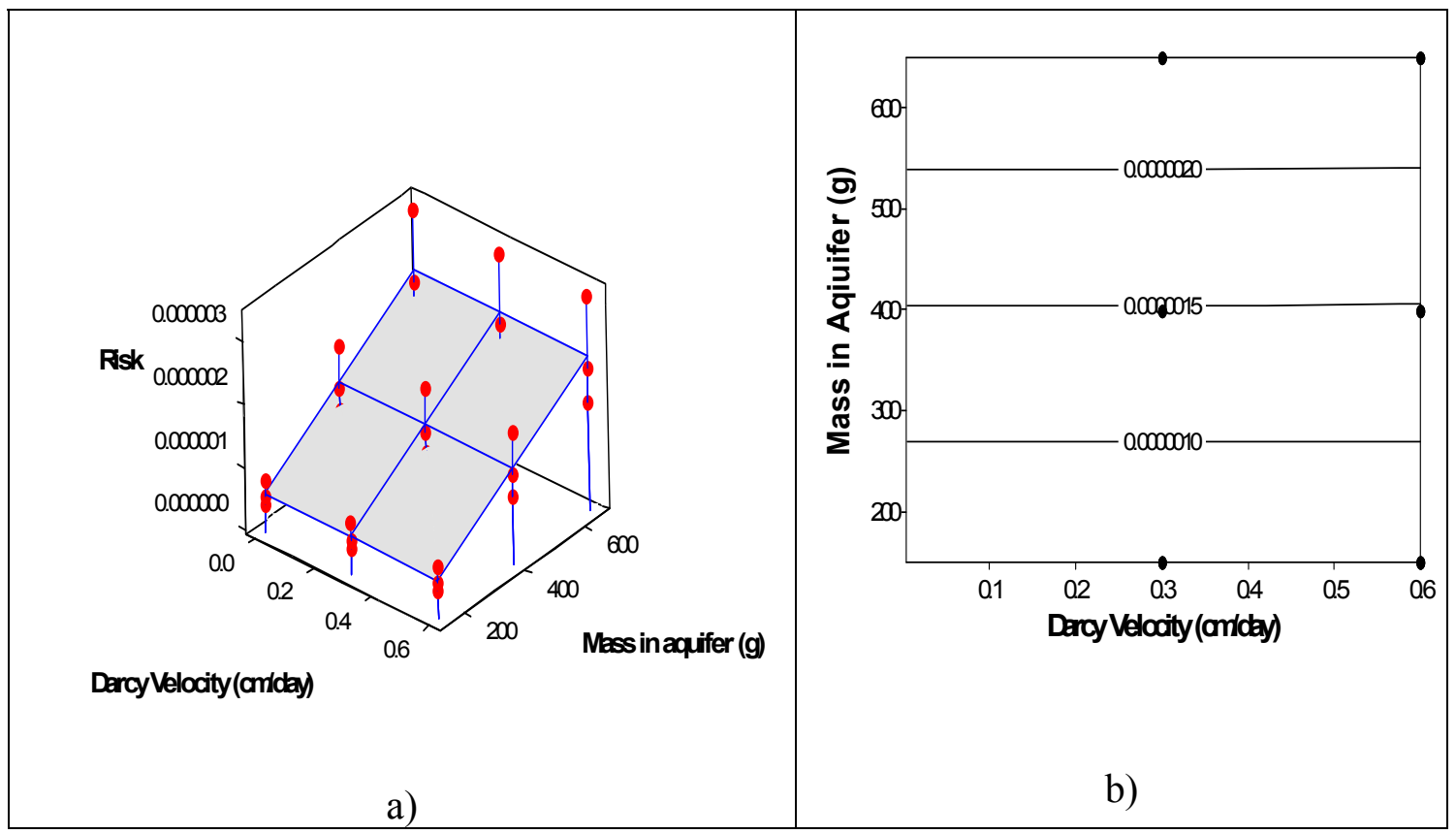

Figure.50. a) Surface plot b) Contour plot of risk vs. mass and Darcy velocity

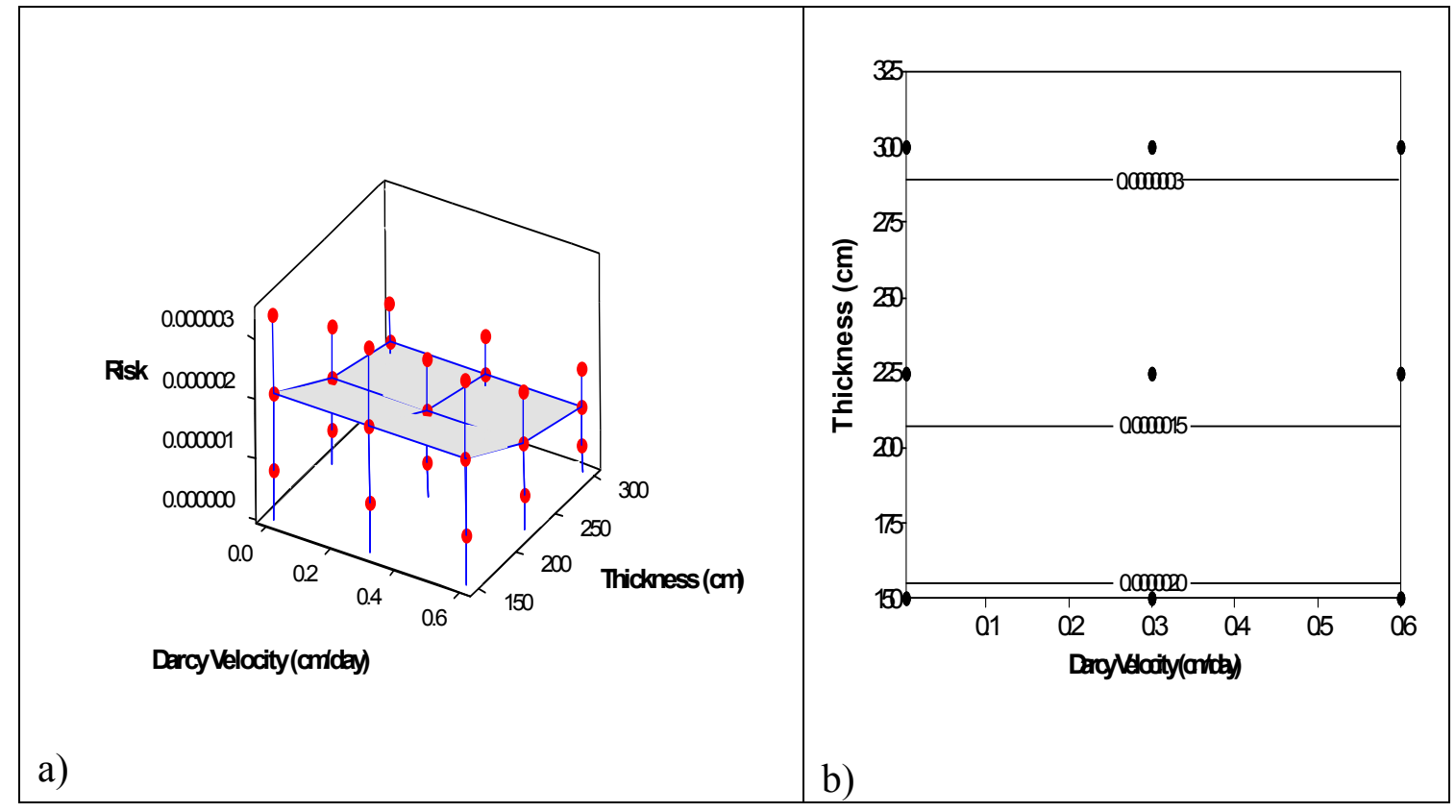

Figure 51. a) Surface plot b) Contour plot of risk vs. thickness and Darcy velocity 


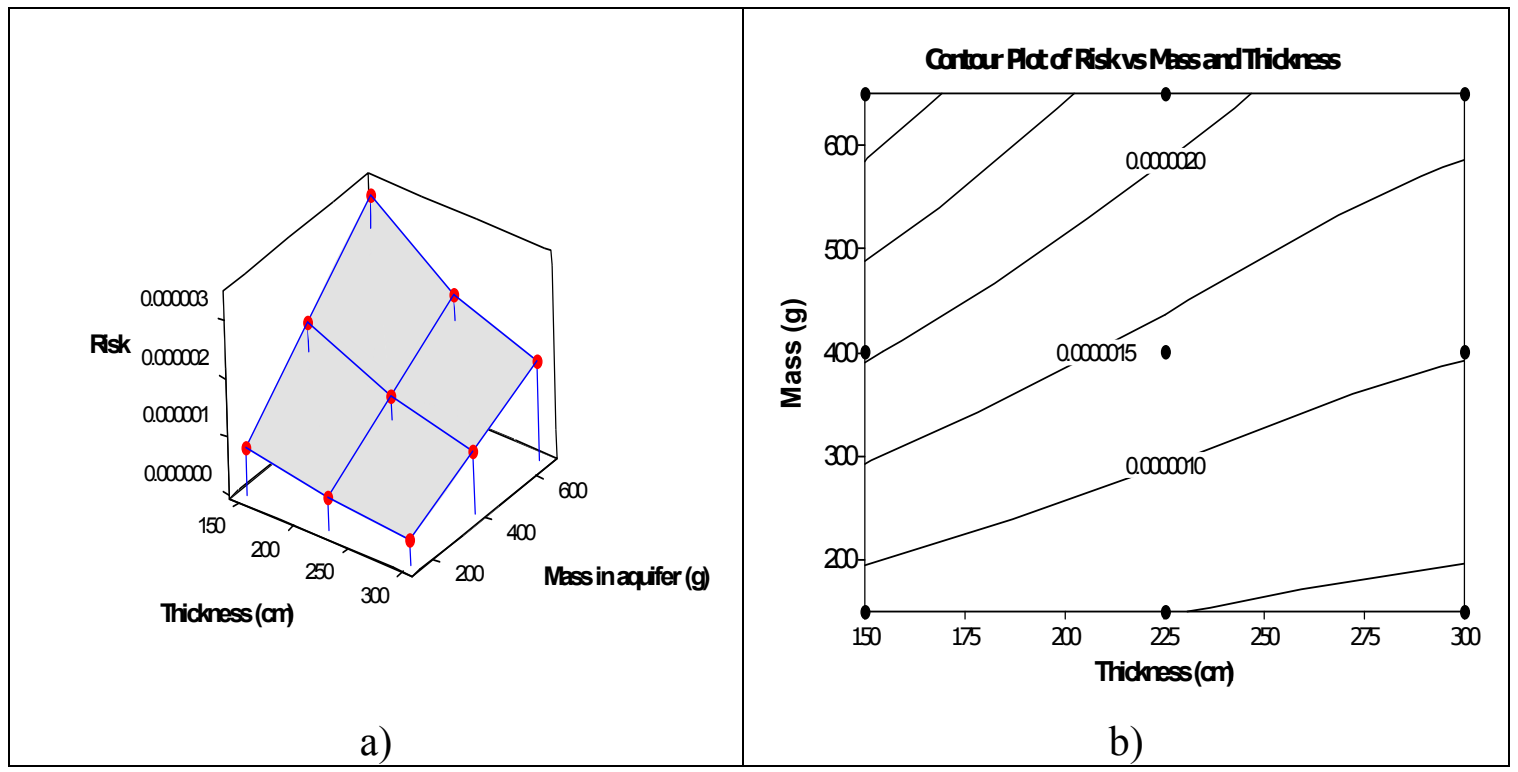

Figure 52. a) Surface plot b) Contour plot of risk vs. mass and thickness

\subsubsection{Soil Sensitivity}

To evaluate the effect of different types of soils on estimated risks, simulations were conducted for five types of soil available in Florida. These included sand, sandy clay, sandy loam, loam, clay loam shown in Table 28. For a defined Darcy velocity of $0.04 \mathrm{~cm} /$ day, soil thickness of $150 \mathrm{~cm}$, and vinyl chloride mass of $330 \mathrm{~g}$ in aquifer; the corresponding risks and hazard indices were estimated. Table 29 presents the estimated risks corresponding to different soil types. The results showed that, sand is the most susceptible soil to risk and hazard resulting from landfill shown in Figure 53 and 54. After sand, sandy clay, sandy loam, loam and clay loam are susceptible soil types to risk respectively.

Table 28. Soil Composition ( based on USDA Textural Diagram) (Whelan et al., 1997)

\begin{tabular}{|c|c|c|c|}
\hline Soil Texture Classification & \% Sand & \% Silt & \% Clay \\
\hline Sand & 92 & 2 & 3 \\
\hline Sandy Clay & 52 & 7 & 41 \\
\hline Sandy Loam & 65 & 25 & 10 \\
\hline Loam & 42 & 38 & 20 \\
\hline Clay Loam & 32 & 35 & 33 \\
\hline
\end{tabular}




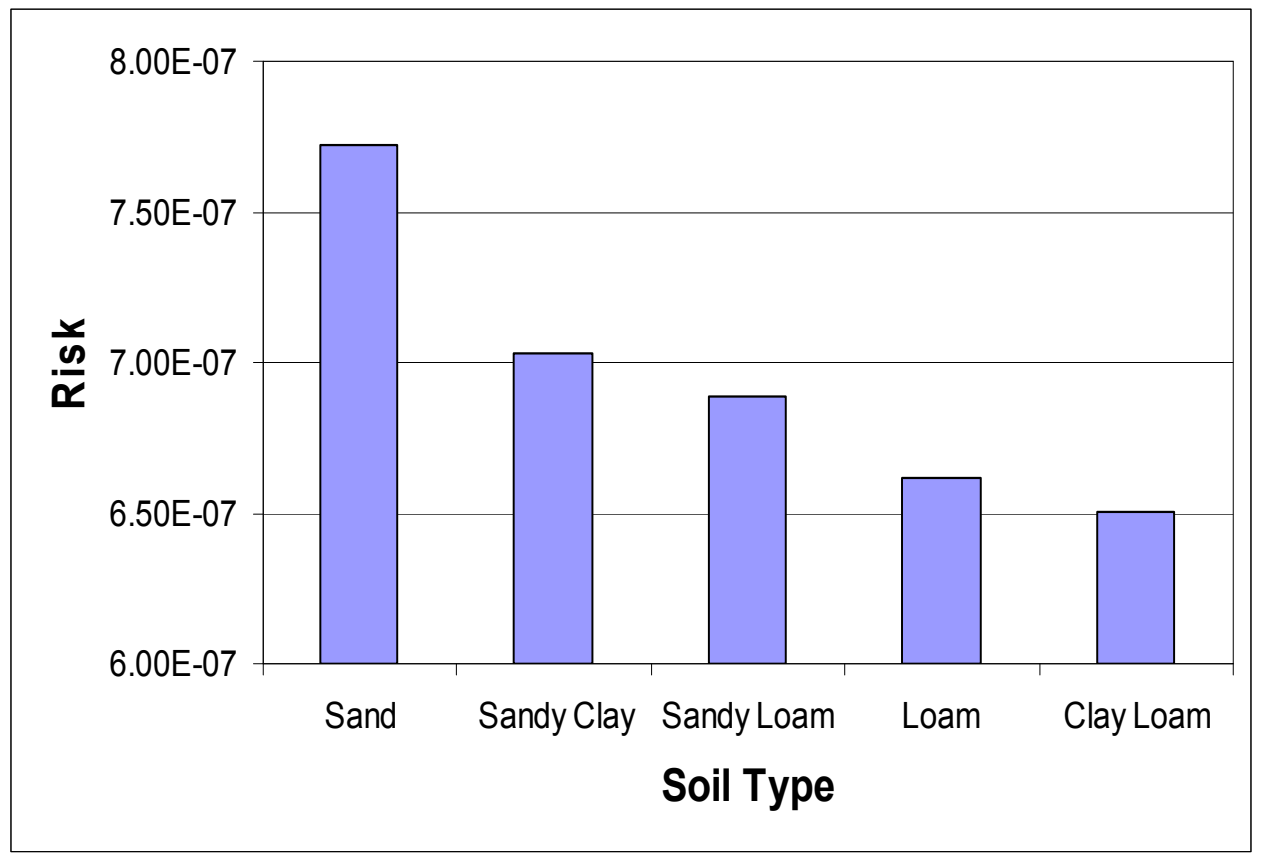

Figure 53. Effect of different soil types on risk.

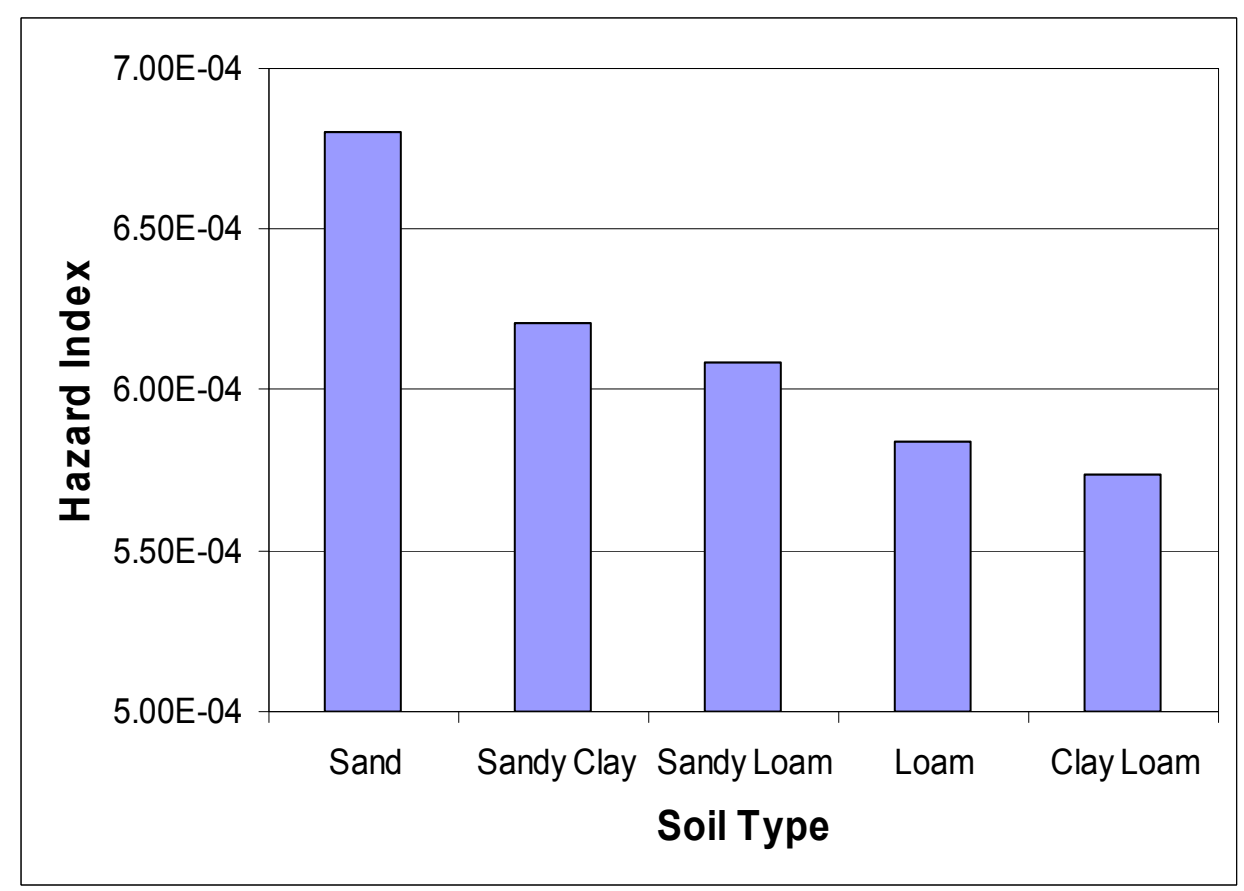

Figure 54. Effect of different soil types on hazard index. 
Table 29. Risk results for different soil types.

\begin{tabular}{|c|c|c|c|c|c|c|c|c|c|c|}
\hline & Sand & & $\begin{array}{l}\text { Sandy } \\
\text { loam }\end{array}$ & & Loam & & $\begin{array}{l}\text { Clay } \\
\text { Loam } \\
\end{array}$ & & $\begin{array}{l}\text { Sandy } \\
\text { Clay }\end{array}$ & \\
\hline Aquifer & HI Non $C^{*}$ & Risk C & HI Non $C^{*}$ & Risk C & HI Non $C^{*}$ & Risk C & HI Non $C^{*}$ & Risk C & HI Non $C^{*}$ & Risk C \\
\hline Ingestion (total) & $3.50 \mathrm{E}-04$ & $6.30 \mathrm{E}-07$ & $3.13 \mathrm{E}-04$ & 5.63E-07 & $3.00 \mathrm{E}-04$ & $5.41 \mathrm{E}-07$ & 2.95E-04 & $5.32 \mathrm{E}-07$ & $3.19 \mathrm{E}-04$ & 5.74E-07 \\
\hline $\begin{array}{l}\text { Leafy } \\
\text { Vegetables }\end{array}$ & $2.03 \mathrm{E}-05$ & $3.67 \mathrm{E}-08$ & $1.82 \mathrm{E}-05$ & $3.28 \mathrm{E}-08$ & $1.75 \mathrm{E}-05$ & $3.15 \mathrm{E}-08$ & $1.72 \mathrm{E}-05$ & 3.09E-08 & $1.86 \mathrm{E}-05$ & $3.35 \mathrm{E}-08$ \\
\hline $\begin{array}{l}\text { Other } \\
\text { Vegetables }\end{array}$ & 2.83E-06 & $5.10 \mathrm{E}-09$ & $2.53 \mathrm{E}-06$ & 4.55E-09 & $2.43 \mathrm{E}-06$ & 4.37E-09 & $2.39 \mathrm{E}-06$ & 4.30E-09 & $2.58 \mathrm{E}-06$ & 4.65E-09 \\
\hline Water & $3.24 \mathrm{E}-04$ & $5.84 \mathrm{E}-07$ & $2.90 \mathrm{E}-04$ & $5.22 \mathrm{E}-07$ & $2.78 \mathrm{E}-04$ & $5.01 \mathrm{E}-07$ & $2.73 \mathrm{E}-04$ & 4.93E-07 & $2.96 \mathrm{E}-04$ & 5.32E-07 \\
\hline $\begin{array}{l}\text { Inhalation } \\
\text { (shower only) }\end{array}$ & $3.19 \mathrm{E}-04$ & $1.21 \mathrm{E}-07$ & $2.85 \mathrm{E}-04$ & $1.07 \mathrm{E}-07$ & $2.74 \mathrm{E}-04$ & $1.03 \mathrm{E}-07$ & 2.69E-04 & $1.01 \mathrm{E}-07$ & 2.91E-04 & $1.10 \mathrm{E}-07$ \\
\hline $\begin{array}{l}\text { Dermal } \\
\text { (shower only) }\end{array}$ & $1.17 \mathrm{E}-05$ & $2.10 \mathrm{E}-08$ & $1.05 \mathrm{E}-05$ & $1.88 \mathrm{E}-08$ & $1.00 \mathrm{E}-05$ & $1.81 \mathrm{E}-08$ & 9.87E-06 & $1.78 \mathrm{E}-08$ & $1.07 \mathrm{E}-05$ & $1.92 \mathrm{E}-08$ \\
\hline Total $* *$ & $6.80 \mathrm{E}-04$ & $7.72 \mathrm{E}-07$ & $6.08 \mathrm{E}-04$ & $6.89 \mathrm{E}-07$ & $5.84 \mathrm{E}-04$ & $6.62 \mathrm{E}-07$ & $5.73 \mathrm{E}-04$ & $6.51 \mathrm{E}-07$ & $6.21 \mathrm{E}-04$ & $7.03 \mathrm{E}-07$ \\
\hline
\end{tabular}

* HI: Hazard Index

Non C: Non Carcinogenic

$\mathrm{C}$ : Carcinogenic

** Total $=$ ingestion $($ total $)+$ inhalation $($ total $)+$ dermal $($ total $)$

Darcy velocity: $0.043 \mathrm{~cm} /$ day

Soil type: Sand

Mass in aquifer: $330 \mathrm{~g}$ Vinyl Cloride

Thickness: $150 \mathrm{~cm}$. 


\section{CHAPTER 7}

\section{SEQUANTIAL DATA IMPROVEMENT FOR DAVIE LANDFILL}

Assessment of a landfill performance requires a systematic approach. An objective compliant and justifiable decision about the post closure care of a landfill requires comprehensive evaluation and interpretation of data and information from the site. One approach which can be used as a decision making tool to extend or shorten the PCC period is to develop a set of measures which can be used to evaluate the relative activity in closed landfills in terms of their overall stability and potential to be threat to human health or the environment (Tansel et al., 2007) During evaluation of the post closure performance of case study landfill to assess the time dependent changes; a range of discrepancies, and problems were encountered with data handling and reporting at various stages of landfill development, operation \& post closure activities. This chapter provides a summary of these challenges that related to the collection, documentation and analyses of data, information and knowledge from Davie landfill. A set of questions have been provided to be assess and verify the quality of monitoring data collected and documented from landfill for future practices.

Davie Landfill has extensive history both during operation and after closure as a result different professional and public entities were involved in data collection and documentation. The roles and responsibilities shared by different entities who had been involved with data collection and analyses during the design, operation, and post closure care of the landfills are summarized in Table 30. With age of the landfill and extent of interaction among the different entities, the data quality is often deteriorates as the amount of data collected increases as schematically presented in Figure 55. 
Table 30. Roles and responsibilities of different entities

\begin{tabular}{|l|l|l|l|}
\hline $\begin{array}{c}\text { Data Collection and } \\
\text { Analysis Field Staff }\end{array}$ & $\begin{array}{c}\text { Landfill Design } \\
\text { and Operation }\end{array}$ & $\begin{array}{c}\text { Regulatory } \\
\text { Oversight }\end{array}$ & $\begin{array}{c}\text { Engineering Analyses } \\
\text { and Reporting }\end{array}$ \\
\hline Sample Collector & Designer & Regulator & Data Collection \\
Lab Analysis & Constructor & Stakeholders & Analysis \\
Technician & Operator & & Interpretation \\
Data Recorder & Monitoring & & \\
Data Interpreter & Personnel & & \\
\hline
\end{tabular}

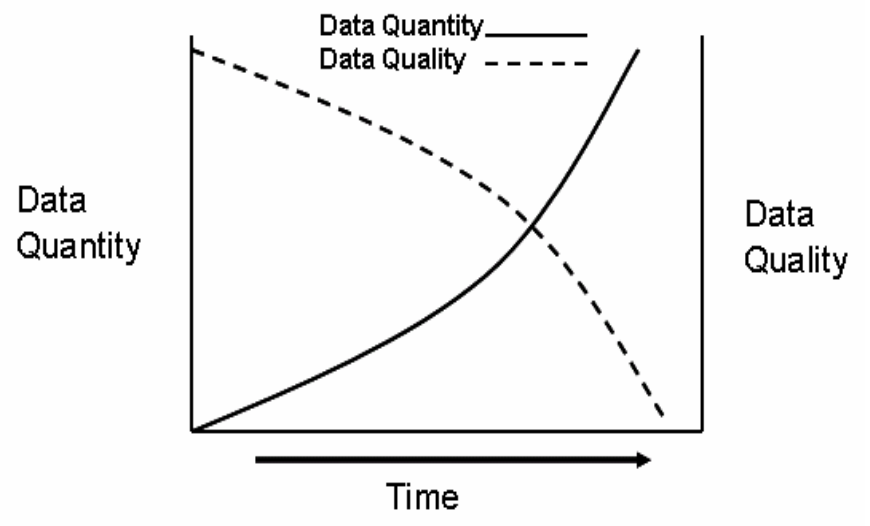

Figure 55. Common trends in quantity and quality during the PCC of landfill

\subsection{Data Quality Assessment and Improvement}

Analysis of existing data and information from landfill may present challenges due to variations in data collection, analysis and reporting methodologies. Table 31 presents the steps used in the tiered approach to compile and improve the data quality for the case study landfill. Each step presented specific challenges depending on the site history, data collection, analysis, and documentation procedures.

Table 31. Data compilation and quality improvements stages.

\begin{tabular}{|c|l|}
\hline Tier No & \multicolumn{1}{c|}{ Scope } \\
\hline 1 & Identification of data availability and format \\
\hline 2 & Preliminary assessment of data quality \\
\hline 3 & Review of data collection procedures and QA/QC protocols \\
\hline 4 & Identification of data gaps and discrepancies \\
\hline 5 & Analysis of time line for changes in end use and other site specific events \\
\hline 6 & $\begin{array}{l}\text { Assessment of data collection instruments and instrument maintenance } \\
\text { protocols }\end{array}$ \\
\hline
\end{tabular}


Data available in field reports and technical memoranda were compared with the knowledge of the technical personnel to improve the data quality as shown in Figure 56. Based on the challenges encountered, a set of questions have been provided to assess the quality of the available data and to avoid possible data analysis pitfalls. Table 32 presents important aspects of data availability to assess the data quality from closed landfills. These check list of questions may be used as a base line to improve the quality of data collection and documentation for current and future practices. A series of strategies were presented to validate and improve the quality of available data.

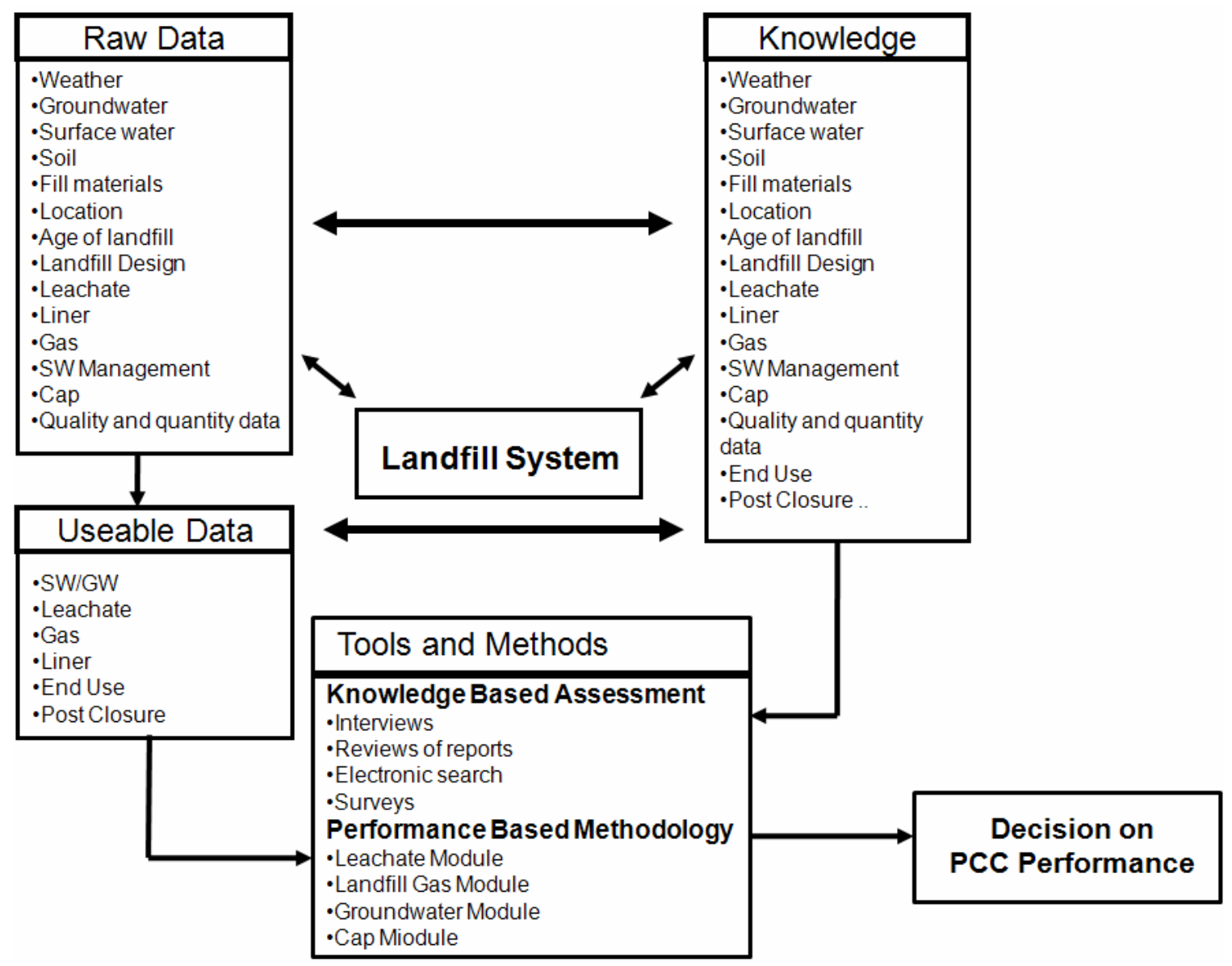

Figure 56. Integrated data and knowledge approach to improve data quality. 
Table 32. Data quality assessment check list.

\begin{tabular}{|c|c|c|c|}
\hline Tier & Questions & Concerns & $\begin{array}{l}\text { Additional sources } \\
\text { for validation }\end{array}$ \\
\hline 1 & $\begin{array}{l}\text { Are the monitoring data available (Gas, } \\
\text { leachate and groundwater) } \\
\text { What is the format of available data } \\
\text { (i.e., digital or paper)? } \\
\text { - Are the digital data easily usable? }\end{array}$ & $\begin{array}{l}\text { Discrepancies in } \\
\text { reported data }\end{array}$ & $\begin{array}{ll}- & \text { Personal } \\
\text { interviews } \\
\text { - } & \text { Public meetings }\end{array}$ \\
\hline 2 & $\begin{array}{l}\text { Are the data needed for assessment of } \\
\text { post closure performance actually } \\
\text { collected? } \\
\text { - Are the data collection and analysis } \\
\text { methods documented in sufficient } \\
\text { detail? } \\
\text { - Are there assumptions made in data } \\
\text { records? } \\
\text { - Are assumptions made during } \\
\text { processing of data recorded? } \\
\text { - Are there gaps in data collection? } \\
\text { Are the maintenance and calibration } \\
\text { records for data collection instruments } \\
\text { documented properly? } \\
\text { - Are the records for monthly average } \\
\text { documented how the monthly average } \\
\text { values were arrived and the locations of } \\
\text { sampling/monitoring points? } \\
\text { Are there established QA/QC protocols } \\
\text { for sampling data collection, and } \\
\text { analysis? } \\
\text { Do detection limits of sample } \\
\text { parameters vary in the records? } \\
\text { Did the ownership of the landfill sites } \\
\text { change over the years? }\end{array}$ & $\begin{array}{ll}\text { - } & \text { Discrepancies in } \\
& \text { reported data } \\
\text { - } & \text { Data not actually } \\
\text { collected } \\
\text { - } \\
\text { - } \\
\text { Data gap. } \\
\text { changes in data } \\
\text { collection procedures } \\
\text { Changes in data } \\
\text { analysis procedures } \\
\text { - Changes in data } \\
\text { reporting procedures }\end{array}$ & $\begin{array}{ll}\text { - } & \text { Personal } \\
\text { interviews } \\
\text { - } & \text { Public meetings } \\
\text { - } & \text { Statistical } \\
& \text { analysis } \\
\text { - } & \text { Extraction of } \\
& \text { usable data } \\
\text { - } & \text { Identification of } \\
& \text { external factors } \\
\text { - } & \text { Assessment of } \\
& \text { conditional } \\
& \text { instruments use }\end{array}$ \\
\hline 3 & $\begin{array}{l}\text { Were the QA/QC procedures for data } \\
\text { collection documented properly with } \\
\text { sufficient detail? } \\
\text { - Were the QA/QC protocols followed } \\
\text { for data collection and analysis } \\
\text { available? } \\
\text { - Were deviations from the established } \\
\text { QA/QC protocols recorded? } \\
\text { - Were some data actually collected for } \\
\text { each record? } \\
\text { - Are frequencies of data collection } \\
\text { activities consistent? } \\
\text { Were samples collected identified as } \\
\text { grab or composite? } \\
\text { Were procedures for measuring and/or } \\
\text { calculating monthly and annual average } \\
\text { flow rates consistent? }\end{array}$ & $\begin{array}{ll}\text { - } & \text { Discrepancies in } \\
\text { reported data } \\
\text { - } & \text { Data not actually } \\
\text { collected } \\
\text { - } & \text { Data gaps } \\
\text { - } & \text { Changes in data } \\
\text { collection procedures } \\
\text { - Changes in data } \\
\text { analysis procedures } \\
\text { - Changes in data } \\
\text { reporting procedures }\end{array}$ & $\begin{array}{ll}\text { - } & \text { Personal } \\
& \text { interviews } \\
\text { - } & \text { Public meetings } \\
\text { - } & \text { Statistical } \\
& \text { analysis } \\
\text { - } & \text { Extraction of } \\
& \text { usable data } \\
\text { - } & \text { Identification of } \\
& \text { external factors } \\
\text { - } & \text { Assessment of } \\
& \text { conditional } \\
& \text { instruments use }\end{array}$ \\
\hline
\end{tabular}




\begin{tabular}{|c|c|c|c|}
\hline 4 & $\begin{array}{l}\text { Are the data processed for extracting } \\
\text { information? } \\
\text { - Is the data processing methodology } \\
\text { appropriate? } \\
\text { What are the assumptions made during } \\
\text { processing of data? } \\
\text { - Are the assumptions justifiable? } \\
\text { Is there any other information source } \\
\text { available to verify how the data were } \\
\text { acquired, processed, and reported in the } \\
\text { available documents }\end{array}$ & $\begin{array}{ll}\text { - } & \text { Discrepancies in } \\
& \text { reported data. } \\
\text { - } & \text { Data not actually } \\
\text { collected } \\
\text { - } & \text { Data gaps } \\
\text { - } & \text { changes in data } \\
\text { - } & \text { Changection procedures } \\
\text { analysis procedures } \\
\text { - Changes in data } \\
\text { reporting procedures }\end{array}$ & $\begin{array}{ll}\text { - } & \text { Personal } \\
& \text { interviews } \\
\text { - } & \text { Public meetings } \\
\text { - } & \text { Statistical } \\
& \text { analysis } \\
\text { - } & \text { Extraction of } \\
& \text { usable data } \\
\text { - } & \text { Identification of } \\
& \text { external factors } \\
\text { - } & \text { Assessment of } \\
& \text { conditional } \\
\text { instruments use }\end{array}$ \\
\hline 5 & $\begin{array}{l}\text { Were there any changes in land use } \\
\text { characteristics? If yes when and what } \\
\text { was done? } \\
\text { - Were there any surface regarding? If } \\
\text { yes when and what was done? }\end{array}$ & $\begin{array}{ll}- & \text { Data gaps } \\
\text { - } & \text { Changes in data } \\
\text { collection procedures } \\
\text { - } & \text { Changes in data } \\
\text { analysis procedures } \\
\text { - } \\
\text { Changes in data } \\
\text { reporting procedures }\end{array}$ & $\begin{array}{ll}\text { - } & \text { Personal } \\
\text { interviews } \\
\text { - } & \text { Public meetings }\end{array}$ \\
\hline 6 & $\begin{array}{l}\text { Are the data collection instruments } \\
\text { maintained properly? } \\
\text { - Are there hidden assumptions in } \\
\text { recorded data? }\end{array}$ & $\begin{array}{ll}\text { - } & \text { Data gaps } \\
\text { - } & \text { Changes in data } \\
\text { collection procedures } \\
\text { - } & \text { Changes in data } \\
\text { analysis procedures } \\
\text { - } \\
\text { Changes in data } \\
\text { reporting procedures }\end{array}$ & $\begin{array}{ll}\text { - } & \text { Personal } \\
\text { interviews } \\
\text { - } & \text { Public meetings }\end{array}$ \\
\hline
\end{tabular}

\subsection{Challenges during Compilation and Analysis of Documented Data}

Analyses of performance data from Davie Landfill can allow development of a decision making framework and help quantify and compare the extent of stabilization being achieved over time. The integrity of the data determines the value of the outcome from the data analyses. The analysis of time dependent changes in the case study landfill presented challenges due to discrepancies in data reporting and inconsistencies in QA/QC protocols during data collection, reporting, and analyses. Significant challenges that were encountered during the analysis of data from the case study landfills are described below. Methodological approaches to resolve some of the challenges are also presented with examples. 


\section{Pitfall \#1: Too many reports and files (first generation data)}

Increasing amounts of data and necessity of maintaining data integrity burdens the Closed Landfill (CLP) Program Staff (Bratsch et al., 2003). In Davie Landfill, groundwater contamination has been experienced over the years, described in extensive reports and technical memoranda (US Corp of Engineers 2005; 2000; USEPA 1995;1994; NOAA 1984) Most often, the reports contained repetitious representations of the same data in different formats without adding any significant new information. The amount of documentation made it difficult to extract the usable data and information from the documents. Some data were in digital format and some were not. The data and information stored in digital formats were not compiled in a systematic manner. Some of the digital data were scanned documents which made the data extraction difficult for future use.

Solution: Creation of an automated system that organizes and graphically displays environmental monitoring data, including analytical and field measurements of ground and surface water, leachate, landfill gas (LFG) condensate, LFG emissions and flare system performance.(Bratsch et al., 2003)

\section{Pitfall \#2: Insufficient documentation in collection/sampling procedures}

Data needs for an objective assessment of the landfill performance includes gas, leachate and groundwater monitoring reports. For the case study landfills, the data logs to extract usable data did not include detailed explanations of the data collection procedures and QA/QC protocols to validate usefulness of the reported information. There were inconsistencies in the reported data for monthly averages, annual averages, the description of grab and composite sampling, detection limits of chemical analyses, 
environmental and other conditions which might have affected the data quality and sample collection procedures such as hurricanes and flooding, repairs and maintenance activities, changes in use of specific areas on or near the sites. Technical problems and bad weather have resulted in deviations in data collection procedures. After review of the reports and interviews of technical staff; the amount of meaningful, objectively documented, and usable data were very limited.

Example: Missing data (gaps between years makes assessment difficult for trend for example Davie landfill was closed in 1987 , but gas monitoring data just starts from 2004. Therefore the calculation of total generated landfill gas was almost impossible.

Solution: Follow the QA/QC protocols.

\section{Pitfall \#3: Variations in data collection strategies and methodology}

Over the years, multiple consulting firms and different teams of engineers and scientists have been involved with different aspects of the landfill management and regulatory issues. Numerous reports and technical memoranda were generated on landfill design, operation and monitoring aspects. As the data have been collected and analyzed by different organizations, laboratories, and consultants; different sampling procedures and QA/QC protocols have been followed. Most common inconsistencies and variations were due to changes in frequency of sampling, sampling methods, reported detection limits (for example there is a gap between 2005- 2008 groundwater data due to device detection sensitivity once it was calibrated to $10 \mathrm{ug} / \mathrm{L}$ and later it was calibrated 100 $\mathrm{ug} / \mathrm{L}$ ), types of instruments and meters used, and documentation of problems.

Solution: Follow the QA/QC protocols. Detection limit specific data review overtime. 
Pitfall \#4: Incompatibility of data used in analyses (i.e., flow and concentration data)

One of the important challenges during data quality assessment was the processed data. When two (or more) data sets were used to estimate a different parameter; the calculated parameter presented some discrepancies with the expected values based on other data and information available. For example, the flow data for leachate and gas generation are often reported as annual and/or monthly averages. The concentration data for leachate and gas quality is often reported as grab samples collected from a leachate sump or gas wells. When loadings estimates of nitrogen, iron, or sodium are calculated by multiplying flow and concentration data, leading to results that can be biased due to the discrepancies between the flow and concentration sampling frequencies, locations, and deviations from standard sampling procedures. In addition large episodic events may reduce the representativeness for the averaged values. For example, in case study landfill, the data showed some correlation with rainfall events shown in Figure 57.

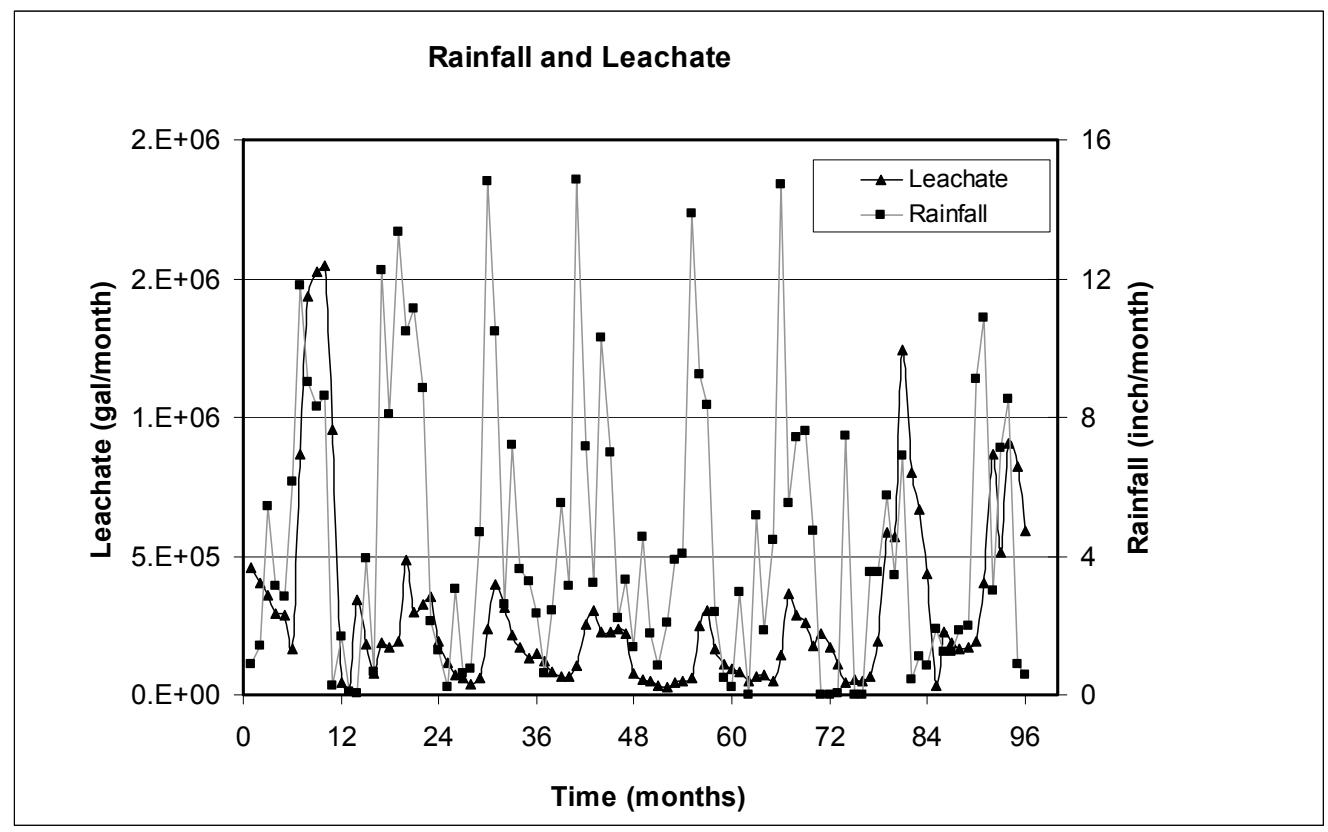

Figure 57. Monthly total leachate vs. monthly total rainfall. 
This implied that the leachate was diluted during the days following a rain event. When the leachate was sampled during these times, the monitoring data showed lower levels of contaminants. To reduce the effect of dilution on leachate quality due to rain in the reported chemical analyses, it was decided to analyze in terms of pollutant loadings (i.e., $\mathrm{Q} \times \mathrm{C}$ ) to determine the trends in leaching of different contaminants from the landfill. However, this created a challenge as the flow data and concentration data collection did not have the similar periodic cycles. The flow data for leachate was collected from a sump as a cumulative flow during the week. The leachate was not always sampled at the same time the weekly average leachate flow was recorded. When the pollutant loads in leachate were calculated as follows:

Load $(\mathrm{Kg} /$ year $)=$ Flow $(\mathrm{cu}$ meter/year) $\mathrm{x}$ concentration $(\mathrm{Kg} / \mathrm{cu}$ meter $)$

The estimated pollutant loads may be in biased due to discrepancies in data collection cycles for flow and concentration data (i.e., monthly, weekly average; grab or composite; total flow, instantaneous flow).

Solution: Try different techniques to eliminate incompatibility. Instead using pollutant loadings, time series analysis was used to identify trends using MINITAB 15 software.

\section{Pitfall \#5: Changes in end use of landfill}

Changes in the end use of landfill over the years may not only affect the data collection protocols but also may result into changes in trends of data collected. The end used changes may affect the structural integrity of the landfill in addition to changes in the landscaping, surface water control structures, drainage patterns, public access, and development and placement of small structures on the facility. Landfills settle as refuse decomposes, and this settlement can lead to damage to the final cover (Bredariol et al., 
1995). During postclosure monitoring, these cracks are repaired, preventing excessive water infiltration. However, cracks that develop after termination of postclosure monitoring may not be repaired, and this could result in leachate production in excess of the estimates (Barlaz et al., 2002) as shown in Figure 58 at Davie Landfill.

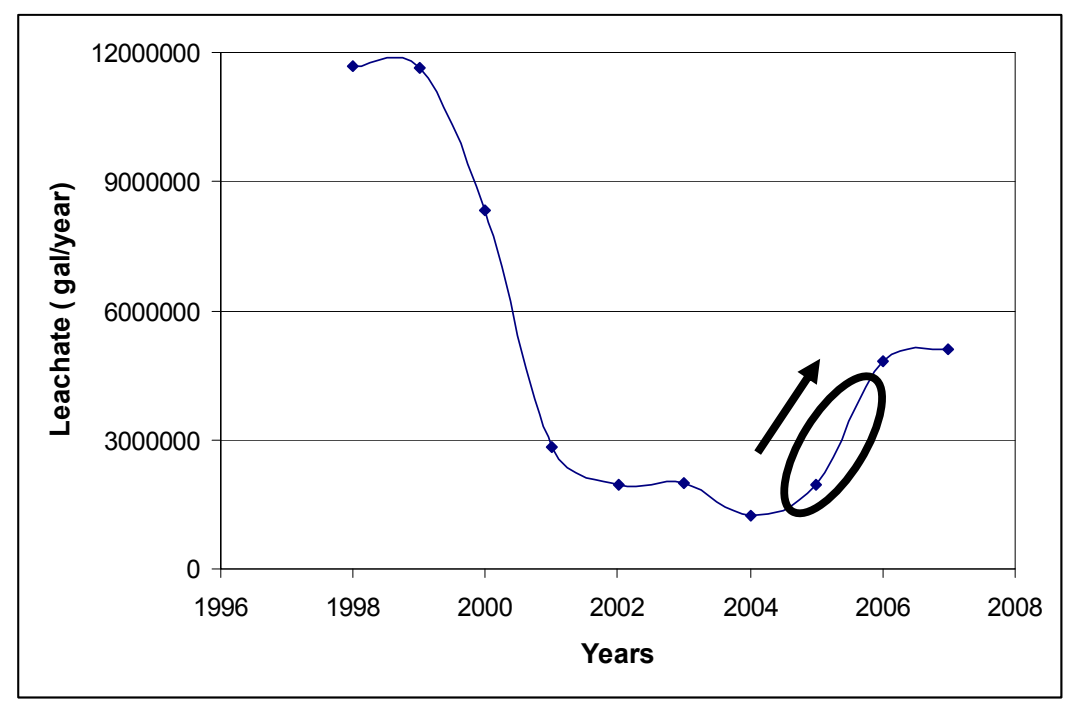

Figure 58. Leachate generation.

At the Davie Landfill, after the site use characteristics changed, some changes are anticipated in gas and groundwater monitoring data. At this site, some of the resurfacing activities included excavation and the removal of the solid waste from one area of the landfill, changing the surface cover characteristics ( i.e. from the grass to concrete for the parking lot), filling in some of the surface water ponds, and changing surface water drainage characteristics. These are significant structural and geotechnical activities that would affect the levels of contaminants detected at the monitoring wells at and around the site.

Solution: Periodic surveys and repairs on cover system 


\section{Pitfall \#6: Erroneous data analyses and reporting}

The quality of the data collected depends on the calibration and accuracy of the monitoring and sampling instruments used. As instruments used or installed at the landfill sites get older, their reliability deteriorates. At Davie Landfill, leachate quantity historically showed a correlation with rainfall as shown in Figure 54. However, inspection of the recent data records showed an unusual trend with no documented explanations. Interviewing the technician responsible for the site revealed that the meter that was used for measuring the leachate quantity was broken and a new meter had been installed. Reassessment of the data by plotting the rainfall versus leachate quantity clearly showed that the new meter had a different calibration scale than the previous meter that was used. Figure 59 presents the annual average data for rainfall in relation to leachate quantity. The annual averages calculated using the old and new meters show the significance of differences in calibration of the meters on the data reported.

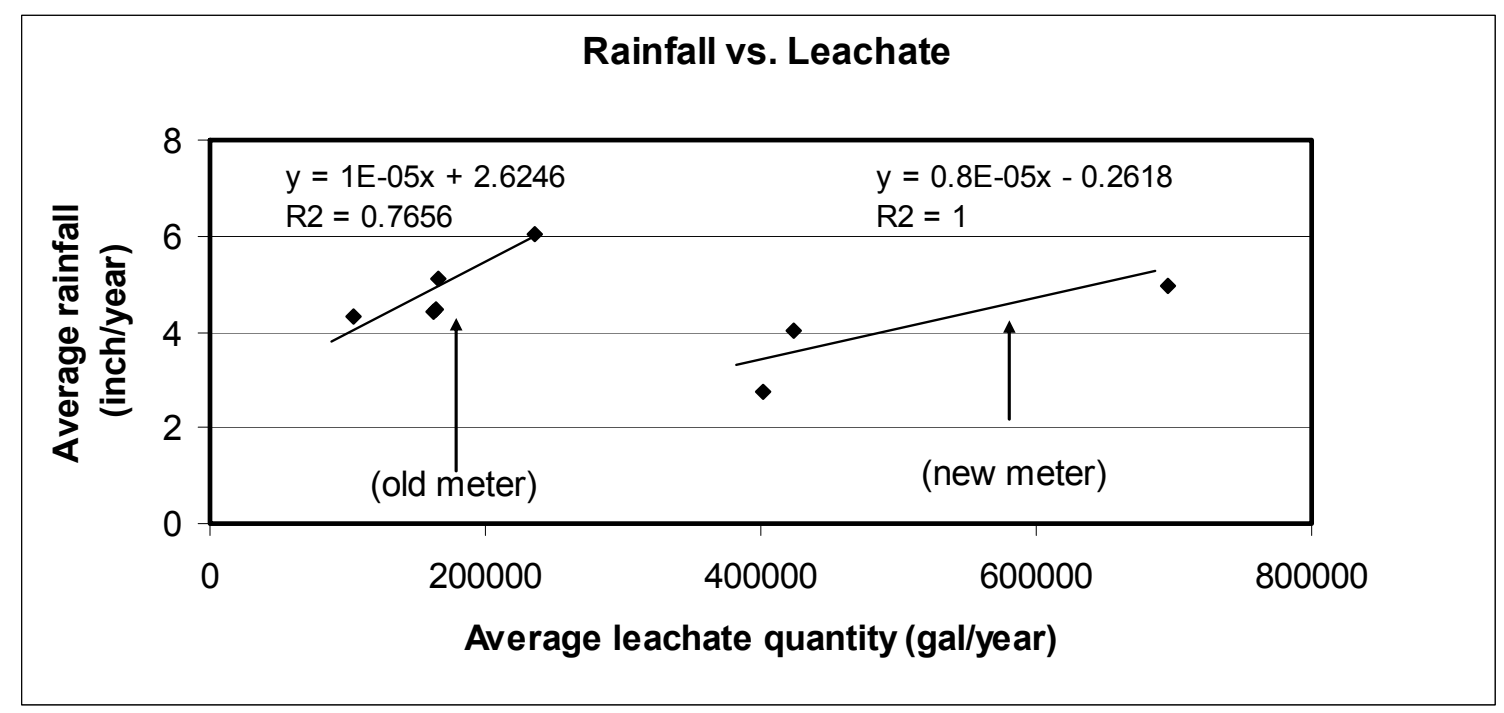

Figure 59. Average rainfall vs. average leachate.

Solution: Instrument specific data review. Carefully calibrate the new equipment. 


\section{Pitfall \#7: Data repetition}

The quality of data assessment depends on accuracy of data collection. Data repetitions on measurements cause serious miscalculations. Figure 60 shows the sodium generation in landfill. The data were used from April 2001 to April 2006. The data fitted fairly well to trend except 2002 September data. When the data examined, it was seen that the April 2002 and September 2002 data were exactly the same. It is possible that this data was not actually collected in the field.

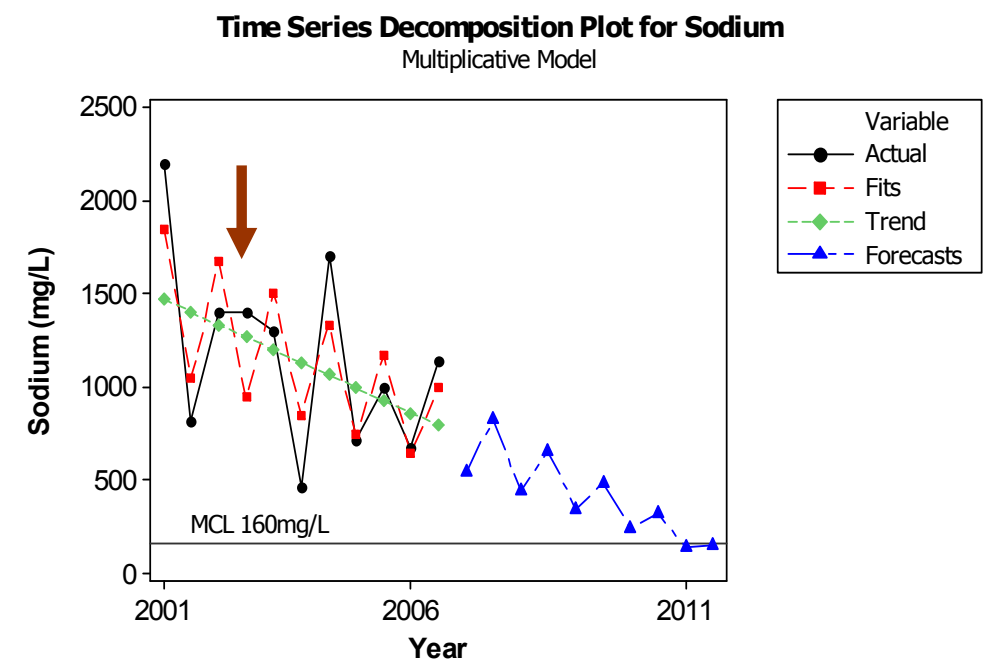

Figure 60. Data repetition.

Solution: Maintain the data accuracy.

\section{Conclusion}

Development of a systematic approach which can be used as a decision making tool to extend or shorten the PCC period requires technically sound and justifiable methods which incorporate analysis and interpretation of available data and information from closed landfill sites. One approach is to develop a set of measures (i.e., metrics) 
which can be used to evaluate the relative activity in closed landfills in terms of their overall stability and potential to be threat to human health or the environment. Important aspects of data assessment include the following,

- Collection of representative samples,

- Documentation of assumption, conditions and unusual events that may have affected the sampling procedures,

- Condition of instruments used for data collection,

- Assumptions used in data processing and documentation,

- Use and justification of appropriate parameters when two or more parameters are used to obtain new information (e.g., QxC).

Based on the changes in data collection methods and staff over the course of landfill development and post closure stages, a number of changes occur in data collection staff, procedures, documentation methods. Development of an adequate PCC methodology requires analysis and interpretation of the available data and information in view of the timeline of events which might have affected the recorded data and subsequent data analyses.

\section{Future Research Suggestions}

During evaluation of the post closure performance of case study landfill to assess the time dependent changes; a range of discrepancies, and problems were encountered with data quality at various stages of landfill development, operation and post closure activities. Based on these challenges that related to the collection, documentation and analyses of data experienced from this case study, some solutions were provided for 
future researchers because the integrity of the data determines the value of the outcome from the data analyses.

- Challenge: Too many reports and files (first generation data)

- Solution: Creation of an automated system that organizes and graphically displays environmental monitoring data,

- Challenge: Data Gaps

- Solution: Fill out the gaps with projections.( LandGEM software was used for theoretical estimates)

- Challenge: Variations in data collection strategies and methodology

- Solution: Follow the QA/QC protocols Detection limit specific data review overtime

- Challenge: Incompatibility of data used in analyses (i.e., flow and concentration data)

- Solution: Try different techniques to eliminate incompatibility.( instead using pollutant loadings, time series analysis was used to identify trends using MINITAB 15 software.)

- Challenge: Changes in end use of landfill

- Solution: Periodic surveys and repairs on cover system

- Challenge: Erroneous data analyses and reporting

- Solution: Instrument specific data review, carefully calibrate the new equipment

- Challenge: Data not collected

- Solution: Maintain the data accuracy 


\section{CHAPTER 8}

\section{ENVIRONMENTALLY CONSCIOUS MANAGEMENT OF WASTES DEPOSITED IN MUNICIPAL SOLID WASTE LANDFILLS}

The 30 year PCC period is long and not cost effective for solid waste management. The 30 year monitoring period can be shortened if the waste materials that result in to contaminants with long periods of persistence and monitoring can be eliminated from entering to the waste stream. In this chapter the leachate quality data were evaluated to forecast the leachate quality trends. Based on the trend analysis results, materials that cause longer monitoring periods were identified in terms of defining a sustainable management of solid waste landfills during the post closure period.

Based on the historical leachate quality data, the parameters with have consistently high concentrations above MCL were identified as key parameters that define the PCC period. The future trends of these parameters and the persistence time to reach their respective MCLs (the rate of disappearance) were calculated using time series analysis. These parameters included chloride, TDS, iron, benzene, and vinyl chloride. PCC period ends for this case study landfill in 2017. Although it ends in 10 years, projected trends for the problem parameters extended the PCC monitoring period 6 to 14 years for Davie landfill. Based on the projections, chloride showed decreasing trend and concentration would be below the MCL by the year 2023 shown in Figure 61a. The zero order rate of disappearance for chloride was estimated $33.73 \mathrm{mg} / \mathrm{L} . y e a r$. TDS is also showed a decreasing trend and MCL will be reached in 2031 shown in Figure $61 \mathrm{~b}$. The zero order rate of disappearance for TDS was estimated $121.07 \mathrm{mg} / \mathrm{L} / \mathrm{year}$. 


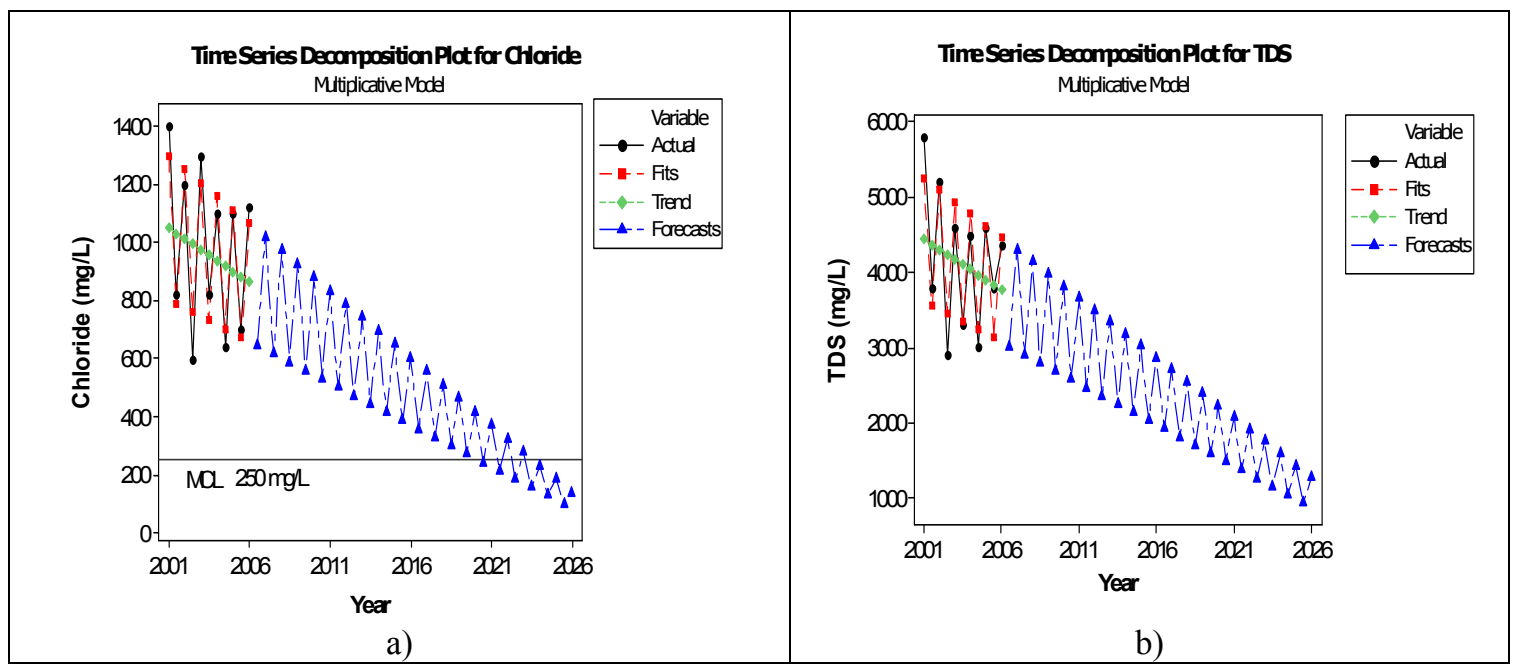

Figure 61. Projected trends for a) vinyl chloride, b) chloride

The general trend for benzene levels in leachate is declining and the projections indicate that benzene concentration in leachate would be below the MCL by the year 2028 shown in Figure 62a. The zero order rate of disappearance for benzene was estimated $0.086 \mathrm{mg} / \mathrm{L} / \mathrm{year}$. The model projections show that iron levels are increasing over time shown in Figure $62 \mathrm{~b}$ The zero order rate of increase for iron were estimated $196.67 \mathrm{mg} / \mathrm{L} /$ year.

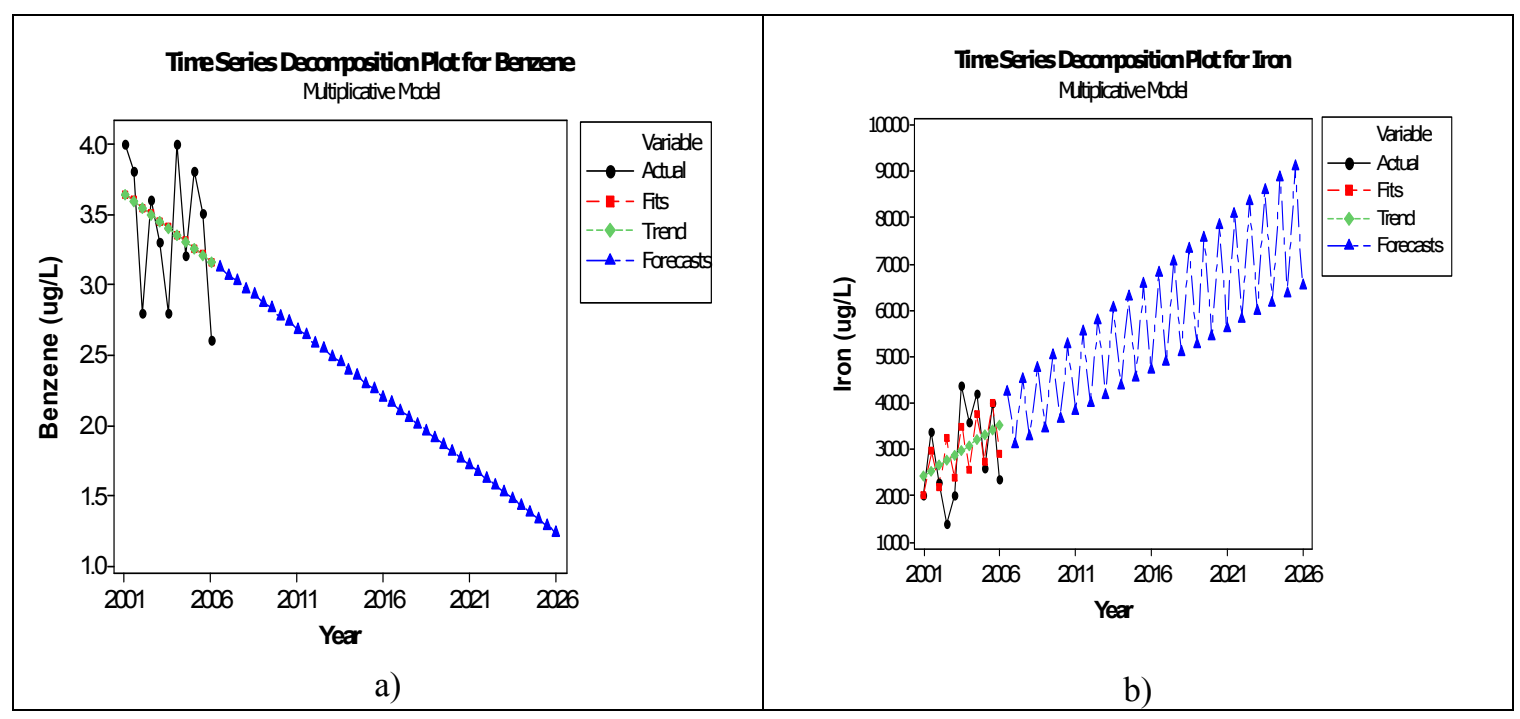

Figure 62. Projected trends for a) TDS, b) iron 
Based on the available data and trend analysis results the rates of disappearance of various parameters in leachate extended monitoring time. Among them, vinyl chloride has the fastest rate of disappearance (time to reach MCL is in 2010) therefore; it would not require long monitoring times after closure and TDS had the slowest rate of disappearance and TDS will persist in landfill leachate, extending the monitoring time for extra 14 years beyond the 30 year PCC period shown in Table 33 .

Table 33. Timetable of degradation of compounds in landfill based on experimental research

\begin{tabular}{|c|c|c|c|c|c|}
\hline $\begin{array}{c}\text { Waste } \\
\text { placed } \\
\mathbf{( 1 9 7 5 - 1 9 8 3 )}\end{array}$ & $\begin{array}{c}\text { Available } \\
\text { Data } \\
\text { Times }\end{array}$ & $\begin{array}{c}\text { Time to } \\
\text { reach } \\
\text { MCL }\end{array}$ & $\begin{array}{c}\text { Monitoring } \\
\text { time beyond } \\
\mathbf{3 0} \text { years }\end{array}$ & $\begin{array}{c}\text { Rate of } \\
\text { disappearance } \\
\text { (mg/L/year) }\end{array}$ & Characteristics \\
\hline Chloride & $2001-2008$ & 2023 & 6 & 33.73 & $\begin{array}{c}\text { Inorganic } \\
\text { anion }\end{array}$ \\
\hline TDS & $2001-2008$ & 2031 & 14 & 121.07 & \\
\hline Iron & $2001-2008$ & - & - & -196.67 & Metal \\
\hline $\begin{array}{c}\text { Vinyl } \\
\text { chloride }\end{array}$ & $2001-2008$ & 2010 & - & 0.099 & VOC \\
\hline Benzene & $2001-2008$ & 2030 & 13 & 0.086 & VOC \\
\hline
\end{tabular}

Due to these problem parameters, extra monitoring needs to be done to meet the regulations. Since these parameters extend the monitoring time, the source of these parameters should be investigated and reduced at the beginning to shorten the monitoring period. The sources of chloride in MSW are paper and plastics. The sources for iron are food and beverage cans, and wood-waste leachates. The main source for TDS is sodium and iron. The sources for benzene are household cleaners (spot remover, degreaser, oven 
cleaner etc.,), stain, varnish, adhesives, cosmetics (nail polish remover). . Some of these materials such as cans, papers are recyclable and they can be eliminated from the beginning with the effective recycle program. Household hazardous waste such as degreasers should be collected and deposited separately. The major sources for each parameter and possible source reduction alternatives were presented in Table 34 . Therefore, the refuse composition of landfills can be defined at the beginning for environmentally conscious management of waste deposited in MSW landfills.

Table 34. Waste Management Options

\begin{tabular}{|c|c|c|}
\hline $\begin{array}{l}\text { Parameters that extend } \\
\text { monitoring time beyond } \\
\qquad \mathbf{3 0} \text { years }\end{array}$ & Source in MSW & $\begin{array}{c}\text { Environmentally conscious } \\
\text { management options }\end{array}$ \\
\hline Chloride (6 years) & Paper, plastics & $\begin{array}{l}\text { - Source separation and } \\
\text { recycling } \\
\text { - Use of green materials } \\
\text { - Reuse }\end{array}$ \\
\hline Vinyl Chloride & Plastics & $\begin{array}{l}\text { - Source separation and } \\
\text { recycling } \\
\text { - Use of green materials } \\
\text { - Reuse }\end{array}$ \\
\hline TDS (14 years) & Paper, salts & $\begin{array}{l}\text { - Source separation and } \\
\text { recycling }\end{array}$ \\
\hline Benzene (13 years) & $\begin{array}{l}\text { Petroleum products, } \\
\text { household cleaners, } \\
\text { cosmetics }\end{array}$ & $\begin{array}{l}\text { - Source separation and } \\
\text { special handling }\end{array}$ \\
\hline Iron (indefinite) & Cans, wood waste & $\begin{array}{l}\text { - Source separation and } \\
\text { recycling }\end{array}$ \\
\hline
\end{tabular}




\section{CHAPTER 9}

\section{RESULTS AND CONCLUSIONS}

The data used in the analyses for the Davie Landfill were provided by Broward County Waste and Recycling Services Solid Waste Operations Division. According to performance based methodology, landfill leachate quality and quantity data, rainfall quantity data, landfill gas composition and quantity data, groundwater monitoring wells quality data and cap integrity were evaluated to forecast the functional stability of the landfill. For the leachate module, the leachate quality and quantity data were analyzed to identify trends. Analyses showed that leachate quantity has been decreasing overtime. Plotted leachate contaminant data showed significant seasonal variations. The samples collected at the end of the dry season (April) higher concentrations of analyzed parameters; and the samples collected at the end of the rainy season (August) had lower concentrations of analyzed parameters due to dilution by infiltrating rain water. Seasonality in graphs was identified by regularly spaced peaks and troughs which had a consistent direction and approximately the similar magnitude every season. Therefore, the data were analyzed by the time series decomposition method which separates the times series into linear and seasonal components, as well as error, for forecasting. Presently total of 46 parameters including 3 field parameters have been monitored in Davie Landfill. Among these parameters, 28 parameters are non-detected parameters (always below detection limit), 8 parameters are always above Maximum Contaminant Level (MCL), Chloride, bicarbonate, sodium, ammonium as N, iron, benzene, vinyl chloride and total dissolved solids), and 10 parameters are below the MCL (1,4 dichlorobenzene, chlorobenzene, cis-1,2 dichloroethylene, dichlorodifluoromethane, 
ethylbenzene, methyl-tert-butyl ether, tetrachloroethene, toluene, xylene and total BTEX). Since there is no comparison standard for landfill leachate parameters, these parameters were compared with MCL standards. The parameters in leachate have showed decreasing trend, except for iron and bicarbonate. The purpose of the leachate module is to determine whether the leachate monitoring practices may be optimized, reduced or discontinued. As a result of the leachate module analysis, the following suggestions were made:

- Significantly reduce or discontinue the monitoring frequency for non detected parameters,

- Reduce monitoring frequency for parameters consistently below MCL,

- Continue monitoring for parameters above MCL, and

- Refine projections of parameters above MCL as more data become available.

For the landfill gas (LFG) module, generated LFG trend was analyzed overtime. Remaining LFG was calculated using Landfill Gas Emissions Model (LandGEM) to evaluate the LGF monitoring can be optimized. The outcomes of landfill gas module showed that remaining LFG generation potential is $0.5 \%$ which indicates $99.5 \%$ of LFG has been eliminated through gas collection system. Therefore, eliminating active LFG management and converting to a passive venting system is acceptable.

The evaluations performed in the groundwater module were based on outcomes of the leachate and landfill gas modules. First groundwater contaminant frequencies were determined and trends were found for each parameter of interest. Most frequently detected parameters were iron, ammonia as N, total Dissolved Solid (TDS), sodium turbidity and zinc and least detected parameters were xylene and metals. These 
parameters have consistent trends. After determining vinyl chloride, chlorobenzene, 1,4 dichlorobenzene, chromium, cadmium, iron, zinc arsenic, ammonia as nitrogen, and xylene as groundwater parameters, the potential human health risks associated with exposure those contaminants were evaluated using Framework for Risk Analysis Multimedia Environmental Systems (FRAMES). The simulations were conducted for those contaminats intake due exposure to contaminated groundwater and pathways (inhalation, ingestion and dermal). Human health risks were evaluated in terms of carcinogenic and noncarcinogenic effects. A factorial analysis was conducted to quantify the effects of Darcy velocity, soil thickness (i.e. depth to groundwater), and contaminant mass in aquifer on estimated risks. Based on the analysis, Darcy velocity showed no effect on risk. The higher concentrations of contaminants in aquifer resulted in higher values of risk and the thicker soil layer resulted in lower values of risks. Since soil layer thickness had a significant effect on estimated health risks, effects of different soil types on estimated risks were investigated. The results showed that soil types from least appropriate to most appropriate for risk management were sand, sandy clay, sandy loam, loam and clay loam. The model showed the changes in both carcinogenic and non carcinogenic risks over time. The risk analysis results showed that, although metals detected in the groundwater are not harmful to the residents living around the Davie Landfill, volatile organic compounds especially vinyl chloride monitoring should be continued. The estimated health risks were directly correlated to levels of vinyl chloride detected in groundwater. Based on groundwater module outcomes combined with risk assessment results, the following suggestions were made: 
- Significantly reduce or discontinue the monitoring frequency for non detected parameters,

- Reduce monitoring frequency for: methyl chloride, methyl tert-butyl ether, xylene, 1,2-dichloroethylene, Chromium (*), Cadmium (*), Arsenic (*), Zinc (*)

$\left(^{*}\right)$ Risk assessment results showed that these parameters are not harmful for residents living around landfill area)

- Continue monitoring for parameters detected above MCL and chlorobenzene,1,4dichlorobenzene, vinyl chloride and,

- Refine projections of parameters above MCL limits as more data become available.

Landfill cap integrity was analyzed using leachate and rainfall correlations and landfill gas data analysis. Based on cap module results, the condition of the cap was impaired. Probably the higher volume of leachate and lower volume of LFG were affected by the existing condition of cap. As a result of the cap module analysis, the following suggestions can be made:

- Continue to conduct periodic walk-over surveys,

- Continue with vegetative cover maintenance,

- Continue to periodically repair erosion damage.

During the evaluation of the post closure performance of Davie landfill, the time dependent changes; a range of discrepancies, and problems that related to the collection, documentation and analyses of data, information and knowledge were encountered and possible solutions made as followings; 
- Create an automated system that organizes and graphically displays environmental monitoring data,

- Follow the QA/QC protocols and maintain the data accuracy.

For the sustainable waste management of future landfills,,materials that cause longer monitoring periods were identified. Based on the source of these materials following suggestion were made;

- Materials such as cans, papers, plastics can be separated before landfilling and recycled.

- Household hazardous waste such as degreasers can be separated before landfilling and handle specially.

Therefore, the refuse composition of landfills can be defined at the beginning for environmentally conscious management of waste deposited in MSW landfills.

\section{Conclusions}

The question of an appropriate PCC period for Florida's landfills requires in-depth case studies focusing on the analysis of the performance data from closed landfills in Florida. Based on data availability, Davie Landfill was identified as case study site for a case-by-case analysis of landfill stability. The performance based PCC decision system developed by Geosyntec Consultants was benefited for the assessment of site conditions to project PCC needs.

It was observed that the monitoring data from the case study landfill had some of the following characteristics:

1. Some correlation between the contaminants detected in leachate and groundwater depending on the groundwater flow direction, 
2. Correlation between leachate quantity and rainfall due to seasonal effects,

3. Changes in leachate quantity due to activities at the sites.

Based on the analysis performed, the following recommendations are provided:

1. Leachate

- Identify trends based on historical records for leachate quality and quantitiy (i.e., increasing, decreasing, steady, variable),

- Reduce or discontinue the monitoring frequency for the parameters that are below the detection limits,

- Reduce monitoring frequency for parameters consistently below MCL,

- Continue monitoring of parameters that are above MCL, and

- Refine projections of parameters above MCL as more data become available.

2. Groundwater

- Identify trends for groundwater quality(i.e., increasing, decreasing, steady, variable),

- Check for any correlations between leachate quality and groundwater quality,

- Check for any potential correlation between groundwater monitoring wells due to groundwater flow,

- Significantly reduce or discontinue the monitoring frequency for parameters that are below detection limit,

- Reduce monitoring frequency for parameters consistently below MCL,

- Continue monitoring for parameters detected above MCL and,

- Refine projections of parameters above MCL limits as more data become available. 


\section{Cap}

- Continue to conduct periodic walk-over surveys,

- Continue with scheduled grass mowing practice, and

- Periodically repair erosion damage.

4. Landfill Gas

- Calculate the remaining landfill gas if it indicates very low generation potential (less than 10\%) eliminate active LFG management and convert to a passive venting system.

In determining the PCC needs, the quality of the monitoring data is very important. The performance based analysis to determine PCC needs requires historical data to make projections for the parameters being monitored. As a result of the long-term data collection and documentation process for closed landfills; the data analysis and identification of trends could be difficult due to discrepancies and inconsistencies in data collection, quality of instruments, changes in data reporting formats, and QA/QC protocols could be significant. For the future landfill management, materials that cause longer monitoring periods (chloride, iron etc.,) can be eliminated via sustainable solid waste management during landfill operations. 


\section{REFERENCES}

Akesson M, Nilsson P. (1997). "Seasonal changes of leachate production and quality from test cells." Journal of Environ Eng., 123(9): 892-900.

Alexander, A., Burklin, C., Singleton, A.(2005) Landfill Gas Emissions Model (LandGEM) Version 3.02 User's Guide, U.S. Environmental Protection Agency Office of Research and Development Washington, DC.

Allen, A, (2001). "Containment landfills: The myth of sustainability", Engineering Geology, 60(1-4), 3-19.

Anderson, P., 2004, “The Myth of Post -Closure Care," Integrated Waste Management Board P\&E Committee Workshop, Sacramento, CA.

Armstrong J. S., Collopy, F., Yokum, T. (2004). "Decomposition by causal forces: A procedure for forecasting complex time series." International Journal of Forecasting, 21(1), 25-36.

Asante-Duah, D.K. (1993).Hazardous Waste Risk Assessment, $1^{\text {st }}$ Ed, CRC Press, Boca Raton, FL.

ATSDR. (2006). Toxicological Profile for Vinyl Chloride, Agency for Toxic Substances and Disease Registry (ATSDR), U.S. Department of Health and Human Services, Public Health Services Atlanta, GA.

Aulin C., Bozkurt S., Moreno L., Neretnieks I. (1997). "The influence of humic substances on the long term mobility of toxic metals." In Proc. Sardinia 1997, 6th Int. Landfill Symp., Cagliari, Italy.

Babendreier, J.E., Castleton, K.J. (2005). "Investigating uncertainty and sensitivity in integrated, multimedia environmental models: tools for FRAMES-3MRA" Environmental Modeling \& Software, 20(8),1043-1055.

Bachus, R. C., Badu-Tweneboah, K. (1995). Landfill containment from top to bottom. World Wastes, 38, 38-42.

Barlaz, M. (2004). Long-Term Landfill Management and Post-Closure Care, 3rd Intercontinental Landfill Research Symposium, Performance-Based System for PostClosure Care at MSW Landfills - A New Approach to the Current 30-Year Time-Based System of Subtitle D, Toya Lake, Japan November 29-December 2, 2004.

Barlaz, M.A., Rooker, A. P., Kjeldsen, P., Gabr, M.A., Borden, R.C. (2002), "Critical Evaluation of Factors Required To Terminate the Postclosure Monitoring Period at Solid Waste Landfills", Environ. Sci. Technol., 36 (16), 3457-3464. 
Barlaz M., Ham, R, Schaefer, D. (1990). "Methane production from municipal refuse: a review of enhancement techniques and microbial dynamics", Critical Reviews in Environmental Control, 19 (6), 557-584.

Barlaz, M.A., Schaefer, D.M., Ham, R.K.(1989). "Bacterial Population Development and Chemical Characteristics of Refuse Decomposition in a Simulated Sanitary Landfill", Appl. Environ. Microhiol., 55(1), 55-65.

Benson, C.H., Barlaz, M.A., Lane D.T., Rawe J.M. (2007). "Practice review of five bioreactor/recirculation landfills", Waste Management, 27 (1),13-29.

Bozkurt S., Aulin C., Moreno L., Neretnieks I. (1997). "Long term release of toxic metals from waste deposits.” Proc. Sardinia 1997, 6th Int. Landfill Symp., In : Christensen, T.,Cossu, R. \& Stegmann, R. (eds) Landfill processes and waste pretreatment. Cagliari, Italy, October 13-17, 1997.

Bozkurt, S., Moreno, L., Neretnieks, I. (2000). "Long-Term Processes in Waste Deposits”, Sci. Total Environ., 250(1), 101-121.

Bratsch, C.G., Verhagen I.(2003) Computing Landfill Data retrieved from http://wasteage.com/mag/waste_computing_landfill_data. accessed May 2008.

Bredariol, A. W.,Martin, J. P., Cheng, S. C., Tull, C. F.(1995). Proceedings of the Specialty Conference on Geotechnical Practice in Waste Disposal; Geotechnical-SpecialPublication, No. 46/2; ASCE: New York.

Broward County Office of Integrated Waste Management Solid Waste Operations Division (2003).Completion Report Davie Landfill Superfund Site, USEPA Region IV. Atlanta, GA.

Buck, J. W. (2001) Requirements for the MEPAS Computed Source Term Release Module. PNNL-SA-32284 (web document), Pacific Northwest National Laboratory, Richland, WA.

Burton, S.Q., Watson-Craik, I.A. (1998). "Ammonia and nitrogen fluxes in landfill sites: applicability to sustainable landfilling.", Waste Manag. Res., 16(1), 41-53.

Butta, T.E., Lockley, E., Oduyemic, K.O.K. (2008). "Risk Assessment of Landfill Disposal Sites, State of The Art", Waste Management, 28(6), 952-964.

Butta, T.E., Oduyemic, K.O.K. (2003). "A Holistic Approach to Concentration Assessment of Hazards in the Risk Assessment of Landfill Leachate", Environment International, 28 (7), 597-608. 
Caldwell, M. (2004). "Performance-Based System for Post-Closure Care at MSW Landfills," Presented at the California Integrated Waste Management Board Workshop on Post-Closure Maintenance Period and Financial Assurance for Post-Closure Maintenance Workshop, Sacramento, CA, December 6, 2004.

Calmano W., Hong J., Forstner U. (1993). "Binding and Mobilization of Heavy Metals in Contaminated Sediments Affected By pH and Redox Potential", Water Sci. Tech., 28(89), 223-235.

Charlatcka R., Cambier P. (2000). "Influence of reducing conditions on solubility of trace metals in contaminated soils", Water Air Soil Pollut., 118 (1-2),143-168.

Christensen, T.H., Kjeldsen, P., Bjerg, P.L., Jensen, D.L., Christensen, J.B., Baun, A., Albrechtsen, H.-J., Heron, G. (2001). "Biogeochemistry of landfill leachate plumes", Appl. Geochem.16, 659-718.

Christensen, T.H., Kjeldsen, P. (1995). Landfill emissions and environmental impact: An introduction. SARDINIA '95, Fifth International Landfill Symposium, Proceedings, Volume lll, pp. 3-12, In: Christensen, T.H., Cossu, R., and Stegmann, R., Eds., CISA, Cagliari, Italy, October 2-6, 1995.

Christensen, T.H., Kjeldsen, P., Stegmann, R. (1992) Effects of landfill management procedures on landfill stabilization and leachate and gas quality. Chapter 2.7 in Landfilling of Waste. Leachate, Christensen, T.H., Cossu, R., and Stegmann, R., Eds., Elsevier Applied Science, London, UK, 119

Christensen, T. H., Kjeldsen, P. (1989). Basic Biochemical Processes in Landfills, In: Sanitary Landfilling: Process, Technology and Environmental Impact, Academic Press, San Diego, CA, 29-49.

Christenson S.C., Cozzarelli, I.M. (2003). The Norman Landfill Environmental Research Site: What Happens to the Waste in Landfills? USGS Fact Sheet FS-040-03.

Chu L.M., Cheung K.C., Wong M.H. (1994). "Variations in The Chemical Properties of Landfill Leachate." Environmental Management 18(1),105-117.

Committee to Assess the Performance of Engineered Barriers, National Research Council. (2007). Assessment of the Performance of Engineered Waste Containment Barriers, National Academies Press, Washington, D.C.

Davis, J.W., Carpenter, C.L.(1990). "Aerobic Biodegradation of Vinyl Chloride in Ground Water Samples” Appl. Environ. Microbiol., 56(12), 3878-3880.

Deipser A. \& Stegmann R. (1994). "The origin and fate of volatile trace components in municipal solid waste landfills", Waste Manage. Res., 12(1), 129-139. 
EARTH, Environmental Assessment \& Risk Tools Homepage, Introduction to the Multimedia Environmental Pollutant Assessment System (MEPAS), http://mepas.pnl.gov/mepas/index.stm (accessed May, 2008).

Evangelidis,A., (2003). “A FRAMES , A Risk Assessment Framework for E-Services”, Electronic Journal of e-Government, 2(1), 21-30.

Farquhar G.J., Rovers ,F.A. (1997). “Gas Production during Refuse Decomposition”, Water, Air \& Soil Pollution 2(2), 483-495.

Faour, A. Reinhart, D.R., You, H. (2007). "First-Order Gas Generation Model Parameters for Wet Landfills", Waste Management, 27 (2007), 946-953.

Garrick, B. J. (2002). "The Use of Risk Assessment to Evaluate Waste Disposal Facilities in The United States of America", Safety Science, 40(1-4), 135-151.

He, R., Shen, D-s., Wang, J-q., He, Y-h., Zhu, Y-m.(2005). "Biological degradation of MSW in a methanogenic reactor using treated leachate recirculation." Process Biochemistry, 40(12):3660-3666.

Hettiaratchi, O.D., Hurtado, C., Hunte, J., Hundal, C., Colbryn, Smith, C. (2007) "The Calgary Biocell: A Case Study in Sustainable Solid Waste Management J.P.A." Proceedings of the International Conference on Sustainable Solid Waste Management, Chennai, India, September 5 - 72007.

Ho C. K., Arnold B. W., Cochran, J.R., Taira, R.Y., Pelton, M.A. (2004). “A Probabilistic Model and Software Tool for Evaluating the Long Term Performance of Landfill Covers" Environmental Modelling \& Software 19(1), 63-88.

Ho, C. K., Goering T. J., Peace, J. L., Miller, M.L. (2007). Probabilistic PerformanceAssessment Modeling of the Mixed Waste Landfill at Sandia National Laboratories (2nd Edition) Sandia Report Sand2007-0170, Sandia National Laboratories, Albuquerque, NM, Livermore, CA.

Kjeldsen, P., Barlaz, M. A., Rooker A. P., Baun, A., Ledin, A., Christensen, T. H. (2002). "Present and Long Term Composition of MSW Landfill Leachate: A review." Critical Reviews in Environmental Science and Technology, 32(4), 297-336.

Klinck, B A., Stuart, M. E., (1999). Human Risk In Relation To Landfill Leachate Quality BGS Technical Report WC/99/17, Nottingham, UK.

Koerner, R. M., Soong, T. Y. (2000). "Leachate In Landfills: The Stability Issues", Geotextiles and Geomembranes, 18(5), 293-309. 
Koliopoulos T. C., Koliopoulou G. (2007). "Risk Analysis of Landfill Gas Emissions: A Report on Mid Auchencarroch Project", Asian J. Exp. Sci., 21(2), 215-226.

LaGoy, P.K.(1994). Risk Assessment-Principles and Applications for Hazardous Waste and Related Sites, Noyes Publications, Park Ridge, NJ.

LaGrega, M. D., Buckingham, P. L., Evans, J. C. (2001). Hazardous Waste Management Environmental Resources Management, 2nd Edition, McGraw Hill, New York, NY.

Lawrence, S.J. (2006). Description, properties, and degradation of selected volatile organic compounds detected in ground water A Review of Selected Literature. U. S. Geological Survey, Atlanta, Georgia. Open-File Report 2006-1338, 62 p., a Web-only publication at http://pubs.usgs.gov/ofr/2006/1338/

Lee, G. F. (2004). Comments on GeoSyntec's 'Performance-Based System for PostClosure Care at MSW Landfills, Presented at ASTSWMO Meeting, Salt Lake City, Utah, 22-24, July 2003," Report of G. Fred Lee \& Associates, El Macero, CA,

Lee, G. F. and Jones-Lee, A.(1993). "Landfill Post-Closure Care: Can Owners Guarantee the Money Will Be There?", Solid Waste and Power, 7, 35-39.

Lee, G.F., Jones-Lee, A. (1992). Municipal Landfill Post-Closure Care Funding: The 30Year Post-Closure Care Myth, Report of G. Fred Lee\& Associates, El Macero, CA.

Lee, G. F., Jones, A. R. (1991). "Groundwater Pollution by Municipal Landfills: Leachate Composition, Detection and Its Water Quality Significance." Proceedings of the National Water Well Association Fifth National Outdoor Action Conference, Las Vegas, NV.

Martensson, A. M., Aulin, C., Wahlberg, O., Argen, S.( 1999). "Effect of Humic Substances on The Mobility of Toxic Metals in A Mature Landfill." Waste Manag. Res., 17(4), 296- 304.

Middeldorp, P.J.M., De Wolf J., Zehnder, A.J.B., Schraa G. (1997). “Enrichment and Properties Of A 1,2,4 Trichlorobenzene-Dechlorinating Methanogenic Microbial Consortium", Applied and Environmental Microbiology, 63(4), 1225-1229.

Minitab 15 StatGuide. Minitab Inc. (2007). Minitab Statistical Software, Release 15 for Windows, State College, PA.

Morris, J., (2005). Performance-Based System for Post-Closure Care at MSW Landfills, EREF Landfill Technical Workshop, Indianapolis, Indiana, August 3-4, 2005. 
Murphy, R. J., Garwell, E., (1998). Infiltration Rates through Landfill Liners State University System of Florida, Florida Center for Solid and Hazardous Waste Management, Gainesville, FL

Nastev, M., Therrien, R., Lefebvre, R., Gélinas P. (2001). “Gas Production and Migration In Landfills and Geological Materials", Journal of Contaminant Hydrology, 52(1-4), 187211.

National Institute for Resources and Environment, (2001), Database for Environmental Fate of Chemicals-Biodegradation Pathways of Chlorobenzenes in A Sediment Sample: National Institute for Resources and Environment, Ibaraki, Japan.

http://riodb.ibase.aist.go.jp/dbefc/index_E.html, (accessed October, 2008.)

Ngoc, U. N., Schnitzer, H.(2009). " Sustainable solutions for solid waste management in Southeast Asian countries.” Waste Management, 29(6): 1982-1995.

NOAA (1984). National Oceanic and Atmospheric Administration, Hazardous Waste Site Report, Munisport Landfill (IV-10) North Miami, FL, http://response.restoration.noaa.gov/book_shelf/217_Munisport_Landfill.pdf (accessed January, 2009)

Paustenbach, D.J. (1989). Introduction: A primer for Conducting Human or Environmental Health Risk Assessments, The Risk Assessment of Environmental and Human Health Hazards. A textbook of Case Studies, John Wiley \& Sons, New York, NY, 1-20.

Pohland F.G., Harper S.A. (1986). "Critical Review and Summary of Leachate and Gas Production from Landfills.” EPA/600/2-86/073, USEPA OSW, Washington DC.

Pohland, F.G., Engelbrecht, R.S. (1976). Impact of Sanitary Landfills: An Overview of Environmental Factors and Control Alternatives, Unpublished report to the American Paper Institute, Georgia Institute of Technology, Atlanta, GA.

Pollard, S.J.T., Smith, R., Longhurst, P.J., Eduljee, G.H., Hall, D.(2006). "Recent Developments in the Application of Risk Analysis to Waste Technologies", Environment International, 32(8), 1010-1020.

Ramanand, K., Balba, M.T., Duffy, James. (1993). "Reductive Dehalogenation of Chlorinated Benzenes and Toluenes under Methanogenic Conditions", Applied and Environmental Microbiology, 59(10), 3266-3272.

Reardon, E, J. (1995.) “Anaerobic Corrosion of Granular Iron: Measurement and Interpretation of Hydrogen Evolution Rates.” Envrion. Sci. Technol. 29, 2936- 2945. 
Reinhart, D,R., Chopra, M.J.,(2000). MSW Landfill Leachate Collection Systems for the New Millennium, State University System of Florida, Florida Center for Solid and Hazardous Waste Management, Gainesville, FL.

Reinhart, D.R., Townsend, T.G. (1997). Landfill Bioreactor Design and Operation, CRC Press, New York, NY.

Reinhart, D.R., Grosh, C.J. (1998). Analysis of Florida MSW landfill leachate quality, Florida Center for Solid and Hazardous Management, Gainesville, FL.

Robinson, H.D. (1995). The technical aspects of controlled waste management. A review of the composition of leachates from domestic wastes in landfill sites, Report for the UK Department of the Environment. Waste Science and Research, Aspinwall \& Company, Ltd., London, UK.

Sanin, F.D., Knappe, D.R.U., Barlaz, M.A. (2000). "Fate of toluene, acetone and 1,2dichloroethane in a laboratory-scale simulated landfill." Water Res., 34(12), 3063-3074.

Schroeder, P. R., Aziz, N. M., Lloyd, C. M. and Zappi, P. A. (1994).The Hydrologic Evaluation of Landfill Performance (HELP) Model:User's Guide for Version 3, EPA/600/R-94/168a U.S.Environmental Protection Agency Office of Research and Development, Washington, DC.

Scully, J.C. (1990). The Fundamentals of Corrosion, Pergamon Press, Oxford, UK.

Shafi, S., Pollard, S.J.T., Smith, R., Sweetman, A., Rosevear, A.(2005) “A Fugacity Approach For Generating a Landfill Gas Trace Component Source Term Proceedings" Sardinia 2005, Tenth International Waste Management and Landfill Symposium. St. Margherita di Pula, Cagliari, Italy, October 3-7, 2005.

Statom., R. A., Thyne G. D., McCray, J. E. (2004). "Temporal Changes in Leachate Chemistry of A Municipal Solid Waste Landfill Cell in Florida, USA", Environmental Geology, 45, 982-991.

Streile, G. P., Shields, K. D., Stroh, J.L., Bagaasen, L. M., Whelan, G., McDonald, J. P., Droppo, J. G., Buck J. W.(1996). The Multimedia Environmental Pollutant Assessment System (MEPAS): Source-Term Release Formulations. PNNL-11248, Pacific Northwest National Laboratory, Richland, WA.

Strenge, D.L. (2001a). Requirements for the MEPAS Chronic Exposure Module, PNNLSA-32274 (web document), Pacific Northwest National Laboratory, Richland, WA.

Strenge, D. L. (2001b). Requirements for the MEPAS Intake Module, PNNL-SA-32285 (web document), Pacific Northwest National Laboratory, Richland, WA. 
Strenge, D. L. (2001c). Requirements for the MEPAS Human Health Impact Module, PNNL-SA-32283 (web document), Pacific Northwest National Laboratory, Richland, WA.

Strenge, D. L., Chamberlain, P. J. (1995). The Multimedia Environmental Pollutant Assessment System (MEPAS): Exposure Pathway and Human Health Impact Assessment Models. PNL-10523, DE-AC06-76RLO 1830Pacific Northwest National Laboratory, Richland, WA.

Tansel, B. (1998). "Land Use and Development Experiences with Closed Landfills", The Journal of Solid Waste Management and Technology, 25(3-4),181-188.

Tansel, B., Reinhart, D.R., Sizirici B., Rayapharapu V.K. (2007). Performance Measures for Comparison of Determining Post Closure Care (PCC) Period in Landfills, ASCE Conf. Proc, 10.1061/40927, (243)322, 1-10.

Tansel, B., Sizirici B., Reinhart, D.R., Kulkarni A. (2008). Performance Based Decision System for Determining Post-Closure Care (PCC) Period in Florida Landfills Final Report, Hinkley Center for Solid and Hazardous Waste Management, Gainesville, FL.

Tchobanoglous, G., Theisen, H.,Vigil, S. (1993). Integrated Solid Waste Management: Engineering Principles and Management Issues, McGrawHill, New York, NY.

Tweeds, (1996). Laxton's Guide to Risk Analysis and Management, ButterworthHeinemann.

U.S. Congress, Office of Technology Assessment. (1989). Facing America's Trash: What Next for Municipal Solid Waste. U.S. Government Printing Office, OTA-O-424, Washington, DC.

U.S. Environmental Protection Agency (USEPA). (1986a). Superfund Public Health Evaluation Manual, EPA 540/1-86/060, Office of Emergency and Remedial Response, USEPA, Washington, DC

U.S Environmental Protection Agency (USEPA). (1996a). US, Guidelines for Reproductive Toxicity Risk Assessment, EPA/630/R-96/009, Risk Assessment Forum Washington, DC.

U.S Environmental Protection Agency (USEPA). (1999a). US, Guidelines for Exposure Assessment. FR 57, EPA/600Z-92/001, Risk Assessment Forum Washington, DC.

USEPA. (1993). Municipal Solid Waste Landfill Criteria - Technical Manual: Chapter 6, Subpart F - Closure and Post-Closure 40 CFR Part 258. www.epa.gov/osw/nonhaz/municipal/landfill/financial/mswclose.htm (accessed January 2007) 
U.S. Environmental Protection Agency (USEPA). (1986b) Guidelines for Carcinogenic risk Assessment. Fed.Regist.51, 33992-34003, Risk Assessment Forum Washington, DC

U.S. Environmental Protection Agency (USEPA). (1986c). Guidelines for Mutagenity Risk Assessment. Fed. Regist. 51, 34006-34012 Risk Assessment Forum Washington, DC

U.S. Environmental Protection Agency (USEPA). (1986d). Guidelines for Health Assessment of Chemical Mixtures. Fed. Regist. 51, 34014-34025, Risk Assessment Forum Washington, DC

U.S. Environmental Protection Agency (USEPA). (1986e). Guidelines for the Health Risk Assessment ff Suspect Developmental Toxicants. Fed. Regist. 51, 34028-34040, Risk Assessment Forum Washington, DC

U.S. Environmental Protection Agency (USEPA). (1986f). Guidelines for Exposure Assessment. Fed. Regist. 51, 34042-34054,_Risk Assessment Forum Washington, DC

U.S. Environmental Protection Agency (USEPA). (1988b). Guidance for Conducting Remedial Investigations and Feasibility Studies. OSWER Directive 9355.3-01. EPA/540/G-89/004. Washington, DC.

U.S. Environmental Protection Agency (USEPA). (2001b). Risk Assessment Guidance For Superfund, Volume I, Human Health Evaluation Manual (Part D, Standardized Planning, Reporting and Review of Superfund Risk Assessments) Final. Office of Solid Waste and Emergency Response, Washington, DC.

U.S. Environmental Protection Agency (USEPA). (2002k). Supplemental Guidance for Developing Soil Screening Levels for Superfund Sites. OSWER 9355.4-24. Office of Solid Waste and Emergency Response, Washington. DC.

U.S. Environmental Protection Agency, (1988). Federal Register, 53,(168), 33345.

U.S. Environmental Protection Agency. (1994). Record of Decision Summary of Remedial Alternative Selection Davie Landfill Site Davie Broward County, Florida, PB94-964051 EPA/ROD/R04-94/180 USEPA Region 4 Atlanta, GA

U.S. Environmental Protection Agency. (1995). Five-Year Review Report for Davie Landfill Site Davie Broward County, Florida, USEPA Region 4 Atlanta, GA.

U.S. Environmental Protection Agency. (1995a). National Primary Drinking Water Regulations, Contaminant Specific Fact Sheets Volatile Organic Chemicals - Technical Version EPA 811-F-95-004-T.

http://www.epa.gov/OGWDW/dwh/t-voc.html (accessed June 2008) 
U.S. Environmental Protection Agency. (1995b). Five-Year Review Report for Davie Landfill Site Davie Broward County, Florida, USEPA Region 4 Atlanta, GA.

United States Corps of Engineers Jacksonville District. (2000). Superfund Five-Year Review Report Davie Landfill Site Davie Broward County, Florida, USEPA Region 4 Atlanta, GA.

United States Corps of Engineers Jacksonville District. (2000). Superfund Five-Year Review Report Davie Landfill Site Davie Broward County, Florida, USEPA Region 4 Atlanta, GA.

United States Corps of Engineers Jacksonville District. (2005). Five-Year Review Report for Davie Landfill Site Davie Broward County, Florida, USEPA Region 4 Atlanta, GA.

United States Corps of Engineers Jacksonville District (2005). Five-Year Review Report for Davie Landfill Site Davie Broward County, Florida, USEPA Region 4 Atlanta, GA.

United States Environmental Protection Agency, Compilation of Air Pollution Emission Factors AP-42 (Fifth edition), USEPA, Research Triangle Park, North Carolina, January 1995.

Vesilind, P.A., Worrell, W., Reinhart, D. (2001). Solid Waste Engineering, Brooks/Cole: Pacific Grove, CA.

Vogel, T.M., McCarty, P.L. (1987a). "Rate of Abiotic Formation of 1,1-Dichloroethylene from 1,1,1-Trichloroethane In Groundwater", Journal of Contaminant Hydrology, 1(3), 299-308.

Vogel, T.M., McCarty, P.L. (1987b). "Abiotic And Biotic Transformation of 1,1,1Trichloroethane Under Methanogenic Conditions”, Environmental Science and Technology, 21(12), 1208-1214.

Vose, D. (2000). Quantitative Risk Analysis: A Guide to Monte Carlo Simulation Modeling, 2nd edition, John Wiley and Sons, Chichester, U.K.

Westlake, K. (1195), Landfill Waste Pollution and Control, Albion Publishing, Chichester, UK.

Whelan, G., Castleton, K. J., Buck J. W., Hoopes, B. L., Pelton, M. A., Strenge D. L., Gelston, G.M., Kickert, R.N.(1997). Concepts of a Framework for Risk Analysis in Multimedia Environmental Systems (FRAMES). PNNL-11748, Pacific Northwest National Laboratory, Richland, WA.

Whittaker, J.J., Buss, S.R., Herbert, A.W., Fermor, M. (2001). Benchmarking and Guidance on The Comparison of Selected Groundwater Risk Assessment Models. 
National Groundwater 7 Contaminated Land Centre (NGACLC) Report NC/00/14, Environment Agency, UK.

Worrall, F., Burt., T.P.(1998). "Decomposition of River Water Nitrate Time-Series Comparing Agricultural and Urban Signals." Science of the Total Environment, 210-211, 153-162.

Zamuda, C. (1989). Superfund Risk Assessment: The Process and Past Experience at Uncontrolled Hazardous Waste Site, The Risk Assessment of Environmental and Human Health Hazards. A textbook of Case Studies, John Wiley \& Sons, New York, NY.

Ammonia in groundwater data retrieved from (http://www.idm.gov.vn/Nguon_luc/Xuat_ban/2005/B25/b43.htm

Arsenic data retrieved from http://www.nab.usace.army.mil/projects/WashingtonDC/springvalley/arsenic/LammPrese ntation.pdf (accessed August, 2008)

Cadmium data retrieved from http://www.epa.gov/safewater/dwh/t-ioc/cadmium.html (accessed August, 2008)

Chromium data retrieved from www.epa.gov/ogwdw/dwh/c-ioc/chromium.html (accessed August, 2008)

Chlorobenzene data retrieved from, http://www.epa.gov/ogwdw000/contaminants/dw_contamfs/chlorobe.html

Cover systems data retrieved from http://www.sandia.gov/caps/designs.htm.(accessed August, 2008)

1,2 Dichlroethene data retrieved from http://www.atsdr.cdc.gov/toxprofiles/tp87-c1.pdf(accessed August, 2008)

1,4-Dichlorobenzene retrieved from http://www.epa.gov/ttn/atw/hlthef/dich-ben.html (accessed August, 2008)

Ethylbenzene data was accessed from www.eco-usa.net/toxics/ethbenz.shtml (October 2008) http://www.epa.gov/OGWDW/dwh/t-voc/ethylben.html (October 2008)

Iron in Minnesota's Groundwater retrieved from http://www.seagrant.umn.edu/groundwater/pdfs/MPCA-Iron.pdf (accessed June, 2008 Limestone in Florida data retrieved from www.swfwmd.state.fl.us/hydrology/sinkholes/brochure.pdf (October ,2008) 
Statistical Analysis of Groundwater Monitoring Data at RCRA Facilities, Interim Final Guidance Document, Apr 1989 retrieved

fromhttp://www.hanford.gov/dqo/project/level5/statanal.pdf (accessed July, 2008)

Vinyl Chloride data retrieved from

http://www.hc-sc.gc.ca/ewh-semt/pubs/water-eau/vinyl chloride/index-eng.php

http://ces.iisc.ernet.in/energy/HC270799/HDL/ENV/enven/vol369.htm

(http://www.isocinfo.com/DocumentRoot/18/Vinyl_Chloride_Contamin.swf)

http://www.atsdr.cdc.gov/toxprofiles/tp87-c1.pdf (September, 2008)

http://www.epa.gov/OGWDW/t-voc/vinylchl.htm (September, 2008)

Xylene data was accessed from

http://www.netspeed.com.au/rdi/cas/xylene.htm (October, 2008) 
VITA

\section{BANU SIZIRICI YILDIZ}

\section{EDUCATION}

2002

Master of Science in Environmental Engineering, Istanbul Technical University (ITU), Istanbul, Turkey

Thesis: Dewatering and Conditioning of Alum Sludge Using Polymers

1999 Bachelor of Science in Environmental Engineering, Istanbul University (IU), Istanbul, Turkey

Thesis: Zero Waste Technology and Applications

\section{EMPLOYMENT}

2007-2009 Research Assistant/ Department of Civil and Environmental Eng., FIU, Miami, FL

2006-2007 Teaching Assistant/ Department of Civil and Environmental Eng., FIU, Miami, FL

2004-2005 Graduate Assistant/ Environmental Engineering Department, ITU, Istanbul, Turkey

2001-2004 Quality Control and System Test Team/ Akbank TAS, Istanbul, Turkey

2000-2001 Environmental Eng. (Researcher), Turkish Marine Research Foundation, Fethiye, Turkey

\section{PUBLICATIONS}

Sizirici B., Tansel., B. "Projection of Landfill Stabilization Period by Time Series Analysis of Leachate Quality and Transformation Trends of VOCs." International Journal of Integrated Waste Management doi:10.1016/j.wasman.2009.09.006 (in press)

Sizirici B., Tansel., B. "Factorial Analysis of Risk Response to Subsoil Characteristics at Closed Solid Waste Landfill: Transport and Exposure Assessment of Vinyl Chloride in Groundwater." submitted to Environmental Monitoring and Assessment.

Sizirici B., Tansel., B. "Data Quality Enchancement with Multi-Parameter Analysis for Post Closure Assessment of Landfill Performance." Submitted to Practice Periodical of Hazardous, Toxic, and Radioactive Waste Management. 
Sizirici B., Tansel., B. "Environmentally Conscious Management of MSW to Reduce Levels and Persistence of Decomposition Byproducts Based on Post Closure Monitoring Data." submitted to Resources, Conservation and Recycling.

Sizirici B., Tansel., B. (2009). "Time Series Analysis of Performance Data from Closed Landfills to Forecast Post Closure Monitoring Needs." proceedings World Environmental \& Water Resources Congress, Kansans City, Missouri, May 17-21, 2009.

Sizirici B., Tansel., B. (2009). "Environmentally Conscious Management Of Wastes DepositedIn Municipal Solid Waste Landfills." proceedings Engineering Sustainability 2009, Pittsburgh, PA April 19-21, 2009.

Sizirici B., Tansel.B., Kumar., V. (2009). “Assessment of Health Risks from a Closed Landfill with FRAMES Model Using Groundwater and Leachate Monitoring Data." proceedings International Conference on Solid Waste Technology and Management, Philadelphia, PA, March 15 - 18, 2009.

Tansel, B., Sizirici B., Reinhart, D.R., Kulkarni A. (2008). Performance Based Decision System forDetermining Post-Closure Care (PCC) Period in Florida Landfills Final Report, Hinkley Center for Solid and Hazardous Waste Management, Gainesville, FL.

Erdim, E., Sizirici, B. and Akca, L. (2004). "Settling and Dewatering Characteristics of Low-Turbidity Alum Sludge." Resources from Sludge: Forging New Frontiers, Raffles Town Club, Singapore, March 2-3 2004.

Sizirici, B., Akca, L., Erdim, E. (2003). "Dewatering and Conditioning of Alum Sludge.” proceedings Environmental Pollution Priorities in Turkey Symposium V, Gebze Yüksek Teknoloji Enstitüsü, Gebze, Kocaeli, Turkey, November 18-19, 2003.

\section{AWARDS/SCHOLARSHIPS/ HONORS}

Awarded, FIU Dissertation Year Fellowship, 2009

Awarded, FIU Teaching Assistantship and Research Assistantship, 2006 to 2009 Awarded by NSF at Engineering Sustainability Conference poster presentation Pittsburgh, PA, 2009

Chi Epsilon, the National Civil Engineering Honor Society, 2008

Sigma Xi, The Scientific Research Honor Society, 2008 